\title{
HYDROLOGY OF AREA 32, EASTERN REGION, INTERIOR COAL PROVINCE, INDIANA
}

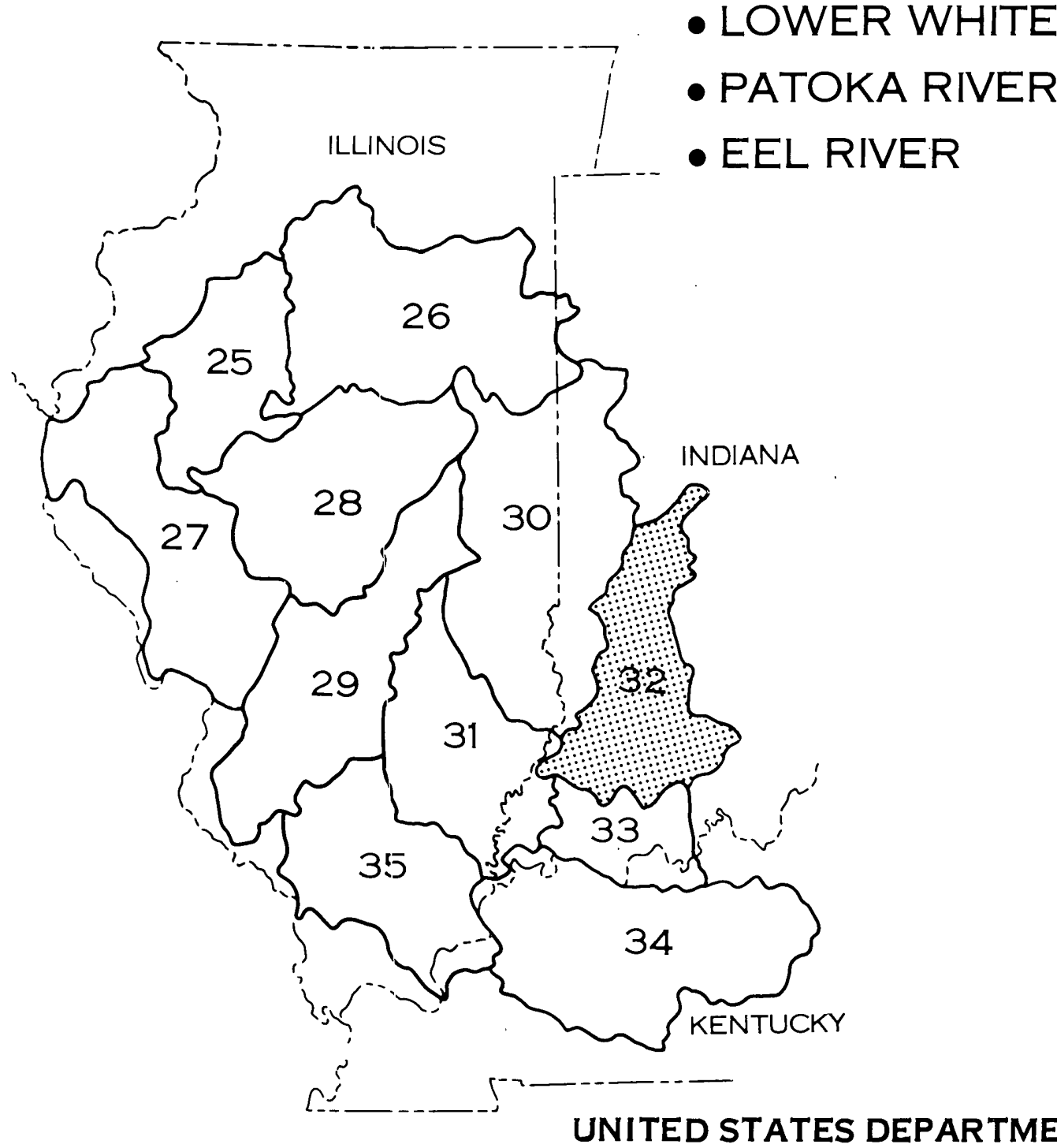




\section{HYDROLOGY OF AREA 32, EASTERN REGION, INTERIOR COAL PROVINCE, INDIANA}

BY

DAVID J. WIANGSNESS, ROBERT L. MILLER, ZELDA CHAPMAN BAILEY, AND CHARLES G. CRAWFORD

U.S GEOLOGICAL SURVEY

WATER-RESOOURCES IN VESTIGATIONS

OPEN-FILE REPORT 81-498

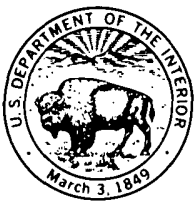

INDIANAPOLIS, INDIANA

AUGUST, 1981 


\section{UNITED STATES DEPARTMENT OF THE INTERIOR}

JAMES G. WATT, SECRETARY

\section{GEOLOGICAL SURVEY}

Doyle G. Frederick, Acting Director

\section{For additional information write to:}

\section{U.S. Geological Survey}

1819 North Meridian Street

Indianapolis, Indiana 46202 


\section{CONTENTS}

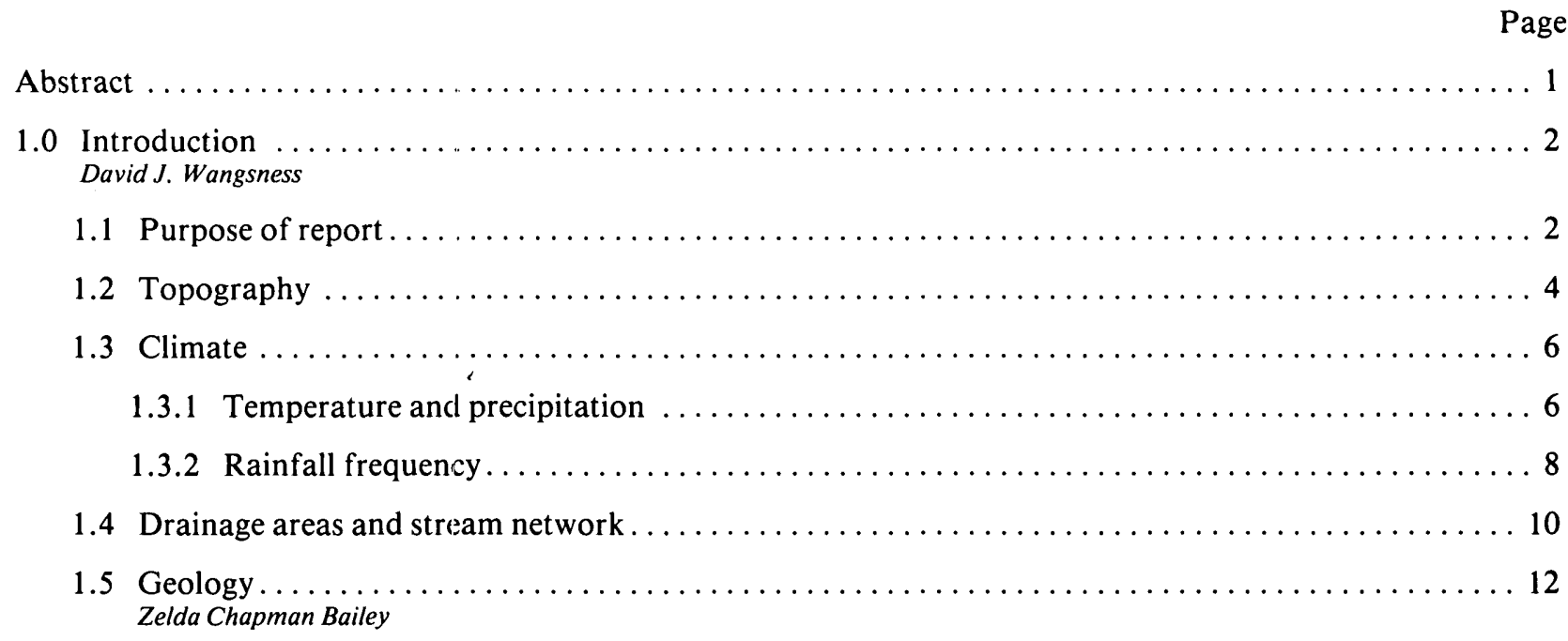

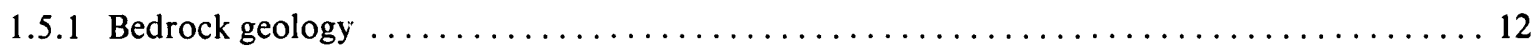

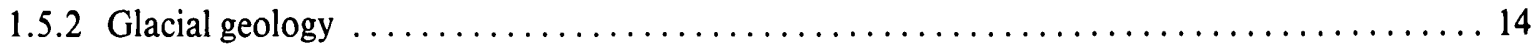

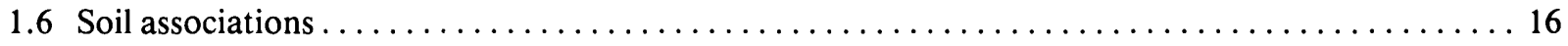

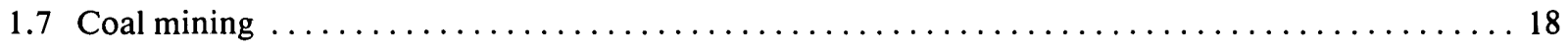

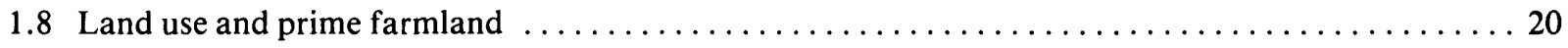

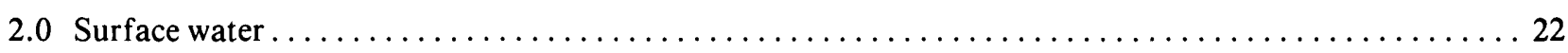

Robert L. Miller

2.1 Gaging stations $\ldots \ldots \ldots \ldots \ldots \ldots \ldots \ldots \ldots \ldots \ldots \ldots \ldots \ldots \ldots \ldots \ldots \ldots \ldots \ldots \ldots \ldots \ldots \ldots \ldots \ldots \ldots \ldots \ldots, 22$

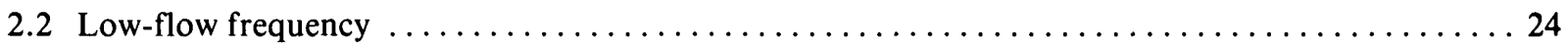

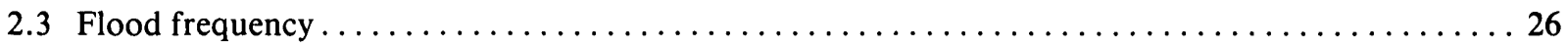

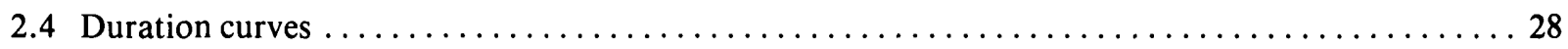

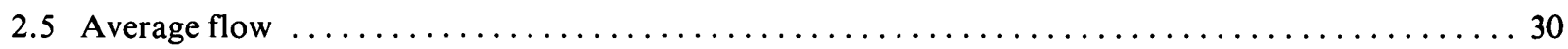

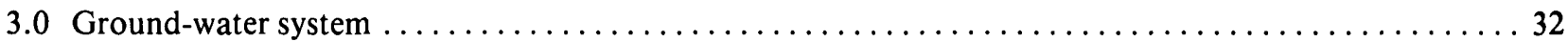
Zelda Chapman Bailey

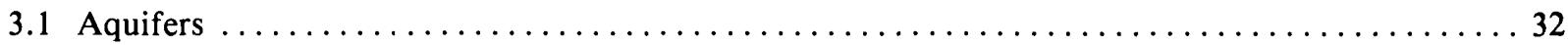

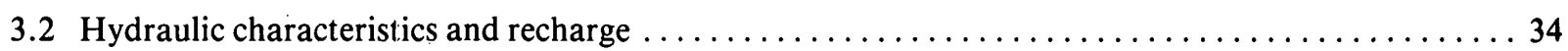

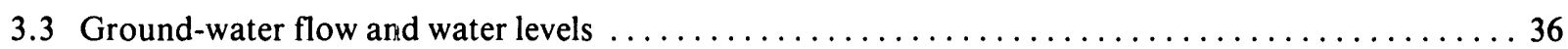

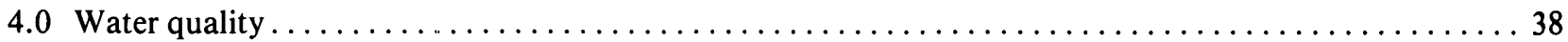

Charles $G$. Crawford

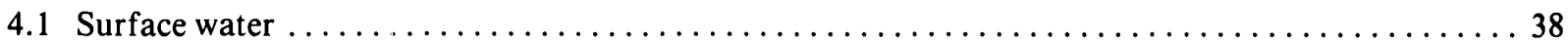

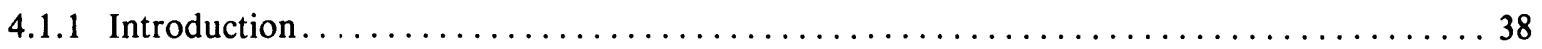

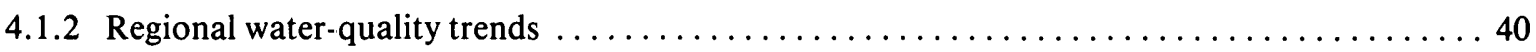




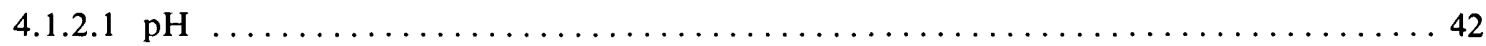

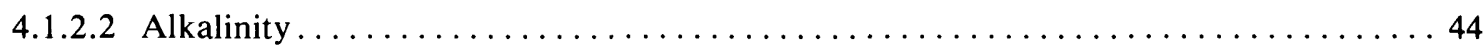

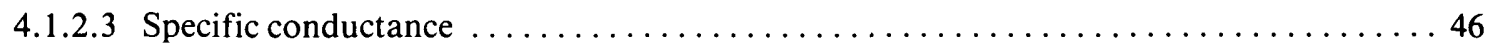

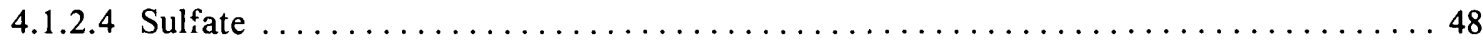

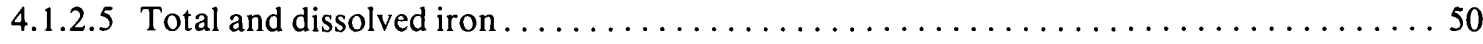

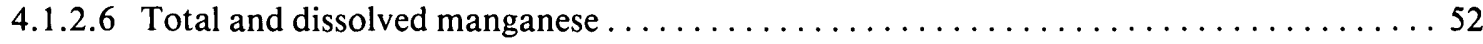

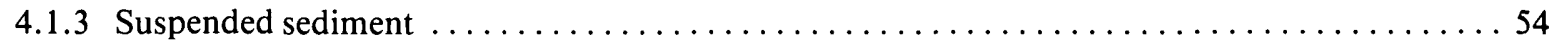

David J. Wangsness

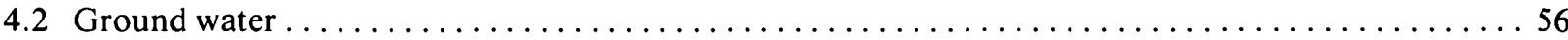

Zelda Chapman Bailey

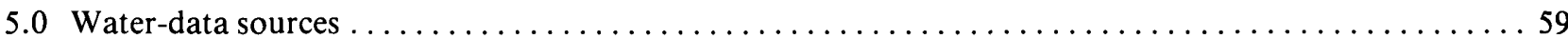
David J. Wangsness

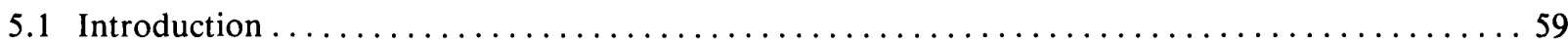

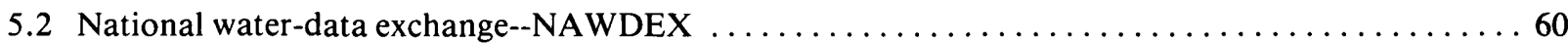

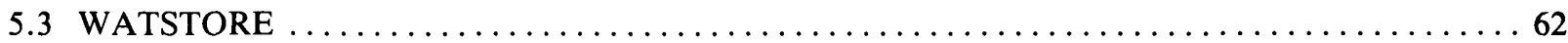

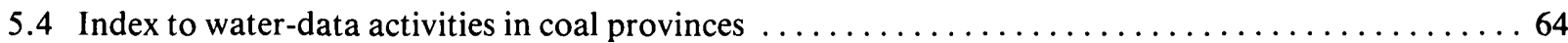

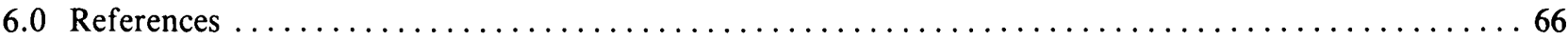

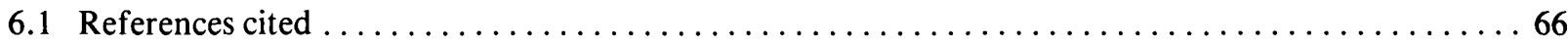

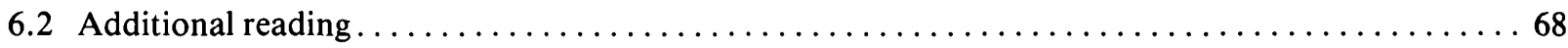

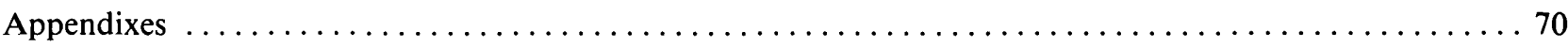

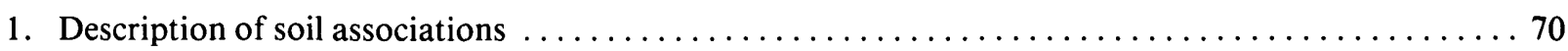

2. Number of determinations of water-quality parameters $\ldots \ldots \ldots \ldots \ldots \ldots \ldots \ldots$ 


\section{FACTORS FOR CONVERTING INCH-POUND UNITS TO INTERNATIONAL SYSTEM OF UNITS (SI)}

For the convenience of readers who may want to use International System of Units (SI), the data may be converted by using the following factors:

\begin{tabular}{|c|c|c|}
\hline Multiply inch-pound units & By & To obtain SI units \\
\hline inch (in) & 25.4 & centimeter $(\mathrm{cm})$ \\
\hline foot $(\mathrm{ft})$ & 0.3048 & meter $(\mathrm{m})$ \\
\hline mile (mi) & 1.609 & kilometer $(\mathrm{km})$ \\
\hline acre & 0.4047 & square hectometer $\left(\mathrm{hm}^{2}\right)$ \\
\hline gallons per minute (gal/min) & 0.0631 & liters per second $(\mathrm{L} / \mathrm{s})$ \\
\hline $\begin{array}{l}\text { gallons per day per foot } \\
{[(\mathrm{gal} / \mathrm{d}) / \mathrm{ft}]}\end{array}$ & 0.0124 & $\begin{array}{l}\text { square meters per day } \\
\qquad\left(\mathrm{m}^{2} / \mathrm{d}\right)\end{array}$ \\
\hline $\begin{array}{l}\text { gallons per day per square } \\
\text { foot }\left[(\mathrm{gal} / \mathrm{d}) / \mathrm{ft}^{2}\right]\end{array}$ & 0.0407 & meters per day $(\mathrm{m} / \mathrm{d})$ \\
\hline cubic feet per second $\left(\mathrm{ft}^{3} / \mathrm{s}\right)$ & 0.0283 & cubic meters per second $\left(\mathrm{m}^{3} / \mathrm{s}\right)$ \\
\hline ton (short, 2,000 pounds) & 1.102 & metric ton $(\mathrm{t})$ \\
\hline
\end{tabular}




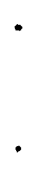




\begin{abstract}
The Eastern Coal Region is divided into 35 separate hydrologic reporting areas. The division is based on hydrologic factors, location, size, and mining activity. Hydrologic units (drainage basins), or parts of units, are combined to form each area. Area 32, at the eastern edge of the Interior Coal Province of the Eastern Coal Region, covers an area of about 10,000 square miles.
\end{abstract}

ABSTRACT

This report on hydrologic conditions and identification of sources of hydrologic: information is designed particularly for use by mine owners, mine operators, and consulting engineers. The report format consists of brief texts and supporting illustrations or tables on a series of hydrologic topics that describe the hydrology of Area 32.

The topography of Area 32 is characterized by lowland plains (Tipton Till Plain, Mitchell Plain, and Wabash Lowland) separated by rugged upland areas (Norman Upland and Crawford Upland). Average elevation ranges from 400 feet in thes southwest to 800 feet in the north.

There were at least three glacial advances (the Kansan, Illinoian, and Wisconsin) into what is now Indiana and neighboring States during the Pleistocene Epoch. About two-thirds of Area 32 was glaciated and is covered with glacial drift. The remaining area is covered by as much as 2 feet of Wisconsin loess (wind-blown material). The underlying bedrock is of Pennsylvanian and Mississippian age. Most of the coal in the study area has been mined from rocks of Pennsylvanian age. The major coal seam in Indiana, the Springfield coal member (Coal V), averages 4.4 feet in thickness. The coals in Area 32 are highly volatile bituminous types B or C and are generally high in sulfur. As of 1978, more than 1 billion tons of coal had been mined from counties within the study area. Reserves for this area have been estimated to total 12 billion tons. During 1978, 17.8 million tons of coal was mined from counties within the study area.

There are two major types of aquifers in Area 32. The bedrock aquifers of Pennsylvanian and Mississippian age generally yield less than 10 gallons per minute. Glacial sand and gravel aquifers are classified in two groups. The first group, the valley train and outwash aquifers, yields 1,000 gallons per minute or more and has a high development potential. The second group, sand and gravel lenses in till or lake sediments, yields from 50 to 500 gallons per minute but has small development potential. The source of ground water is precipitation percolating into the aquifers. The aquifers discharge ground water by seepage into streams, evapotranspiration, springs, and pumpage. Although flow in the bedrock and the glacial sand and gravel aquifers is locally toward a major stream, there is also a regional component of flow in the bedrock aquifer toward the southwest.

Median concentrations of dissolved solids, iron, and sulfate in glacial aquifers are $316,0.5$, and 22 milligrams per liter, respectively. Median concentrations of dissolved solids, iron, manganese, and sulfate in bedrock aquifers are $391,0.5,0.02$, and 20 milligrams per liter, respectively. The dissolvedsolids concentration of ground water generally increases with depth.

The major rivers draining the study area are the White, Eel, and Patoka Rivers. Records of discharge for streams and rivers in the study area indicate that the dominant factor affecting average annual flow is size of drainage area. Size of drainage area also affects low flow. Some streams with small drainage areas (less than 100 square miles) have 7-day, 10-year low flows of zero. Surficial aquifers have minimal discharge to these streams, and, therefore, the streams have little sustained streamflow. In large rivers like the White, the drainage area, as well as channel slope and stream length, are controlling factors of low flow and flood magnitude. In the smaller rivers and streams, precipitation index (rainfall minus snowfall and evapotranspiration) is the controlling factor of flood magnitude. Precipitation index in Area 32 is higher than that in much of the rest of the State, and, therefore, flood magnitude for streams and rivers in the study area is high compared to that in the rest of the State.

Considerably more coal has been mined in the south and west parts of Area 32, primarily in Pike, Knox, and Greene Counties, than in the remainder of the area. The exposure and the oxidation of pyrite and marcasite probably causes specific conductance and concentrations of sulfate, iron, and manganese to be higher, and $\mathrm{pH}$ and alkalinity to be lower, in the surface water in the west half of the study area than in the east half. 


\title{
1.0 INTRODUCTION \\ 1.1 Purpose of Report
}

\section{REPORT SUMMARIZES AVAILABLE HYDROLOGIC AND WATER-QUALITY DATA}

\author{
The need for hydrologic data and other information from coal-mining \\ regions has become critical since enactment of the Surface Mining \\ Control and Reclamation Act of 1977 (Public Law 95-87). Section \\ $505(b)(11)$ of the Act requires that extensive information about \\ the probable hydrologic consequences of mining and reclamation \\ be included in mining-permit applications so that the regulatory \\ authority can determine the probable cumulative impact of mining \\ on the hydrology of the area. The purpose of this report is to \\ summarize available hydrologic information for a subbasin in \\ southwestern Indiana and to document the source of this information.
}

Coal is the most abundant fossil fuel in the United States, and the amount mined will probably be increased to meet our energy demands. Surface mining and reclamation have affected surface waters in much of the continental United States. Water quality has been degraded by acid mine drainage, and hydrologic conditions have been altered by mining.

The U.S. Geological Survey is helping to provide the hydrologic data, particularly the water-quality data required by Public Law 95-87. This report is a summary of several reports, maps, oral communications, written communications, and computer data files from Federal and State agencies in Indiana. Much of the data has been summarized, but only some has been interpreted.

The area of study represents the hydrologic unit or drainage-basin area shown on the adjoining map (fig. 1.1). The unit boundary crosses political and hydrologic boundaries and, therefore, creates prob- lems in nomenclature and data presentation. Adjoining counties may have a slightly different name for virtually the same geologic formation, soil type, and physiographic unit. The authors have not standardized the nomenclature used by the various reporting agencies but instead have presented the information as it was reported. Much of the data are presented by State and county rather than by drainage areas; for example, coal production and land use. Where a part of any county is within the unit boundary, data for the whole county are usually presented. Where a total figure is presented, such as total coal production for the study unit, that figure represents the total for all counties contacted by the study unit boundary and not just the total for the area within the unit boundaries. Therefore, some figures may be inflated because they represent a larger area than is shown, and the same county figures may be presented in other area reports in the series of coal-hydrology reports if a county lies in parts of two or more study areas. 


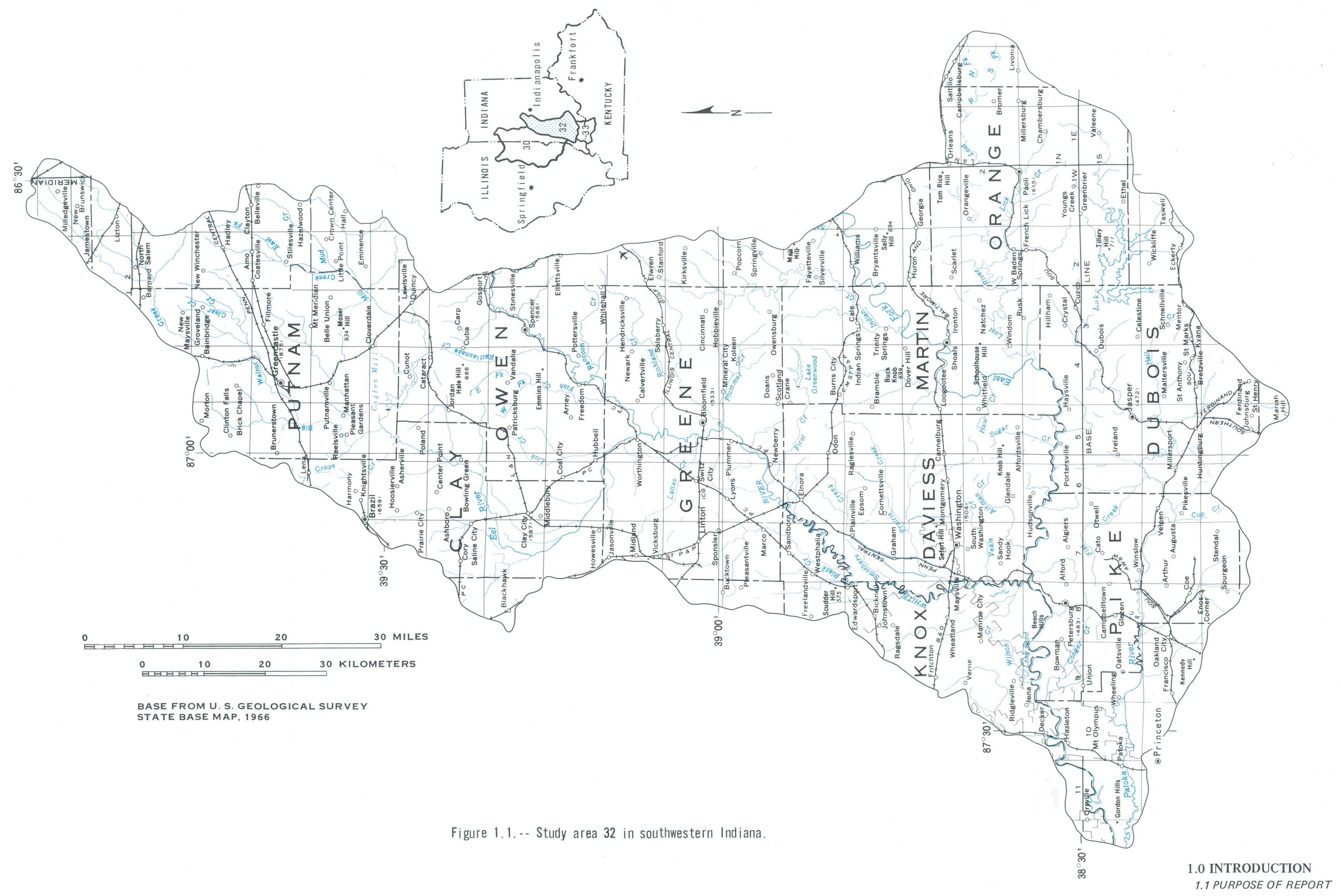




\title{
1.0 INTRODUCTION \\ 1.2 Topography
}

\section{TOPOGRAPHY CONSISTS OF LOWLANDS SEPARATED BY RUGGED UPLANDS}

\author{
The topography has been formed by at least three glacial advances as \\ well as by natural processes such as weathering, stream \\ erosion, and mass movement. The area is characterized \\ by lowland plains separated by rugged upland areas. \\ Average elevation ranges from 400 feet in the southwest to \\ 800 feet in the north.
}

The land slopes generally southwest, and its average elevation ranges from 800 feet (NGVD of 1929) in the north to less than 400 feet in the southwest. The north and much of the west parts of the study area were glaciated during the Illinoian Glaciation. The north part was glaciated again during the Wisconsin Glaciation. There are five physiographic units in the study area: (1) the Tipton Till Plain, (2) the Norman Upland, (3) the Mitchell Plain, (4) the Wabash Lowland, and (5) the Crawford Upland.

The Tipton Till Plain is a depositional plain of low relief, underlain by thick glacial till and modified only slightly by postglacial stream erosion. The plain is nearly flat to gently rolling and is crossed by several low and poorly developed end moraines. The flatness of the plain is broken by low eskers, esker troughs, and melt-water drainways that trend southwest.

The Norman Upland is a mature landform characterized by flat-topped narrow divides, steep slopes, and deep, V-shaped valleys. The upland is underlain by resistant siltstone and interbedded softer shale.

Some of the best developed karst topography in the world lies within the Mitchell Plain. Most of the solution features are developed on the St. Louis and Ste. Genevieve Limestones. The plain, an area of low relief, is covered with numerous sinkholes and other solution features such as dolines and swallow holes. The limestone bedrock contains a system of channels and caverns.

The Wabash Lowland, underlain by till, lacustrine, outwash, and alluvial sediments, is characterized by extensivly aggraded valleys. The lowland is a broad plain with low rolling hills. The glaciated north part of the lowland has less relief than the unglaciated south part.

The Crawford Upland is underlain by alternating layers of sandstone, shale, and limestone that have been eroded to produce a maturely dissected upland with diverse topographic features. The area has a well developed drainage pattern. Drainage divides are generally flat but narrow, and the valley walls are steep. The bottoms of the large valleys are moderately wide flood plains and are usually the only level land in the area. (See Schneider, 1966, p. 40-50).

The adjoining map (fig. 1.2) shows the extent of the physiographic regions and elevations of the area. 


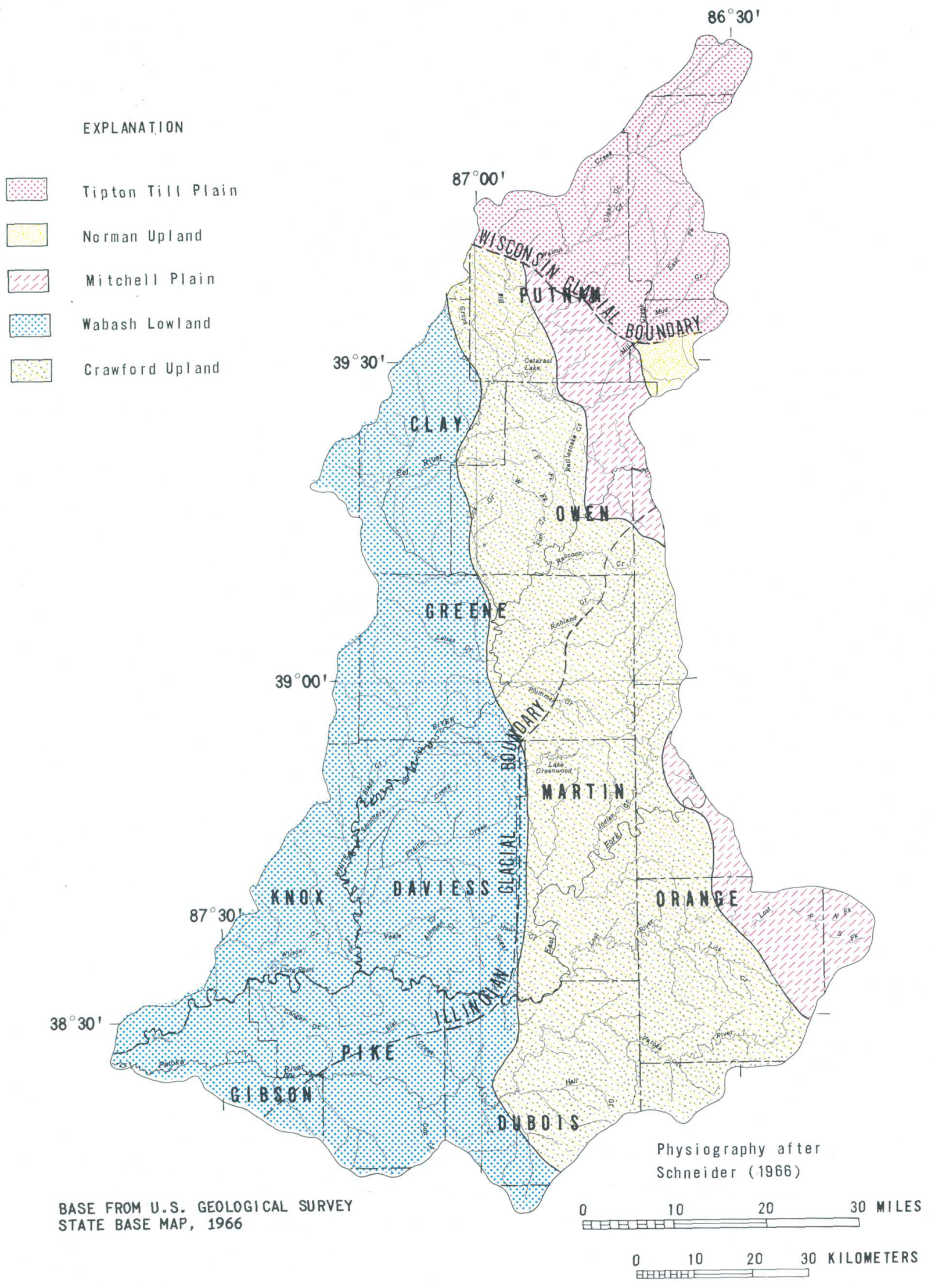

Figure 1.2.-- Glacial extent and physiographic regions. 


\author{
1.0 INTRODUCTION \\ 1.3 Climate \\ 1.3.1 Temperature and Precipitation
}

\title{
TEMPERATURE AND PRECIPITATION IN AREA 32 ARE REPRESENTATIVE OF MIDDLE-LATITUDE STATES
}

\author{
Annual temperature averages $55.0^{\circ} \mathrm{F}$, and average monthly temperature \\ ranges from $32.5^{\circ} \mathrm{F}$ in January to $77.0^{\circ} \mathrm{F}$ in July. Annual \\ precipitation averages 39 inches in the north and 45 inches \\ in the south. Maximum average monthly precipitation is 4.3 \\ inches in the south and 4.6 inches in the north during \\ spring. Average monthly minimum precipitation is 2.4 \\ inches, usually in October.
}

Indiana has warm summers and cool winters because of its location in the middle latitudes $\left(38^{\circ}\right.$ to nearly $42^{\circ}$ north) in the interior of a large continent. Temperature can change significantly every few days, when surges of polar air or tropical air move into the State, but changes more frequently during the winter months than during the summer. A winter may be unusually cold or a summer may be cool if the influence of polar air is continuous. If tropical air dominates the weather, a winter may be mild and the summer may be unusually warm. The interaction of tropical and polar air masses of contrasting temperature and density develops low-pressure centers that generally move east through or near Indiana. This interaction normally results in abundant precipitation. Average annual snowfall ranges from 10 inches in the south part of the State to 40 inches in the north. Thunderstorms are generated by storm frontal activity or are formed locally by daytime convective air currents, which is important when evapotranspiration exceeds rainfall. This weather pattern also generates tornadoes, primarily in May and June. Indiana ranks 12th in tornado frequency but States to the south and west rank higher. (See Schaal, 1959, and Schaal, 1966, p. 156 to 170. .)

The climate of Area 32 differs from that of northern Indiana because of the difference in latitude. The average annual temperature for the period 1941 through 1970 is $55.0^{\circ} \mathrm{F}$. The maximum monthly mean temperature at Washington, Daviess Coun- ty, Ind., is $77.0^{\circ} \mathrm{F}$ during July, and the minimum mean monthly temperature is $32.5^{\circ} \mathrm{F}$ during January. Mean maximum and minimum temperatures to the north are $2^{\circ}$ to $4^{\circ} \mathrm{F}$ lower, respectively. The date of the first freeze in autumn is usually between October 15 and 20. The date of the last freeze in the spring is usually in mid- to late April. Annual precipitation averages 39 inches in the north and 45 inches in the south. Average snowfall generally ranges from 10 inches in the north to 20 inches in the south. Maximum mean monthly precipitation (generally in late spring) ranges from 4.3 inches in the south to 4.6 inches in the north. Minimum mean monthly precipitation (usually in October) averages 2.4 inches. Rates of pan evaporation are not available for the study area. However, pan evaporation during July is 8 inches at Evansville, Ind., compared with 6 to 7 inches at Oaklandon, 12 miles northeast of Indianapolis. In October, pan evaporation is about 2.5 inches at Evansville and Oaklandon. $\mathrm{Hu}$ midity ranges from 40 to 90 percent. (Information in this paragraph is from Allen Shipe, Indianapolis, National Weather Service, written commun., January, 1980.)

The adjoining maps (fig. 1.3.1) show mean annual precipitation and air-temperature curves for southwest Indiana and eastern Illinois, and mean monthly precipitation and air-temperature graphs for selected locations within the area. 


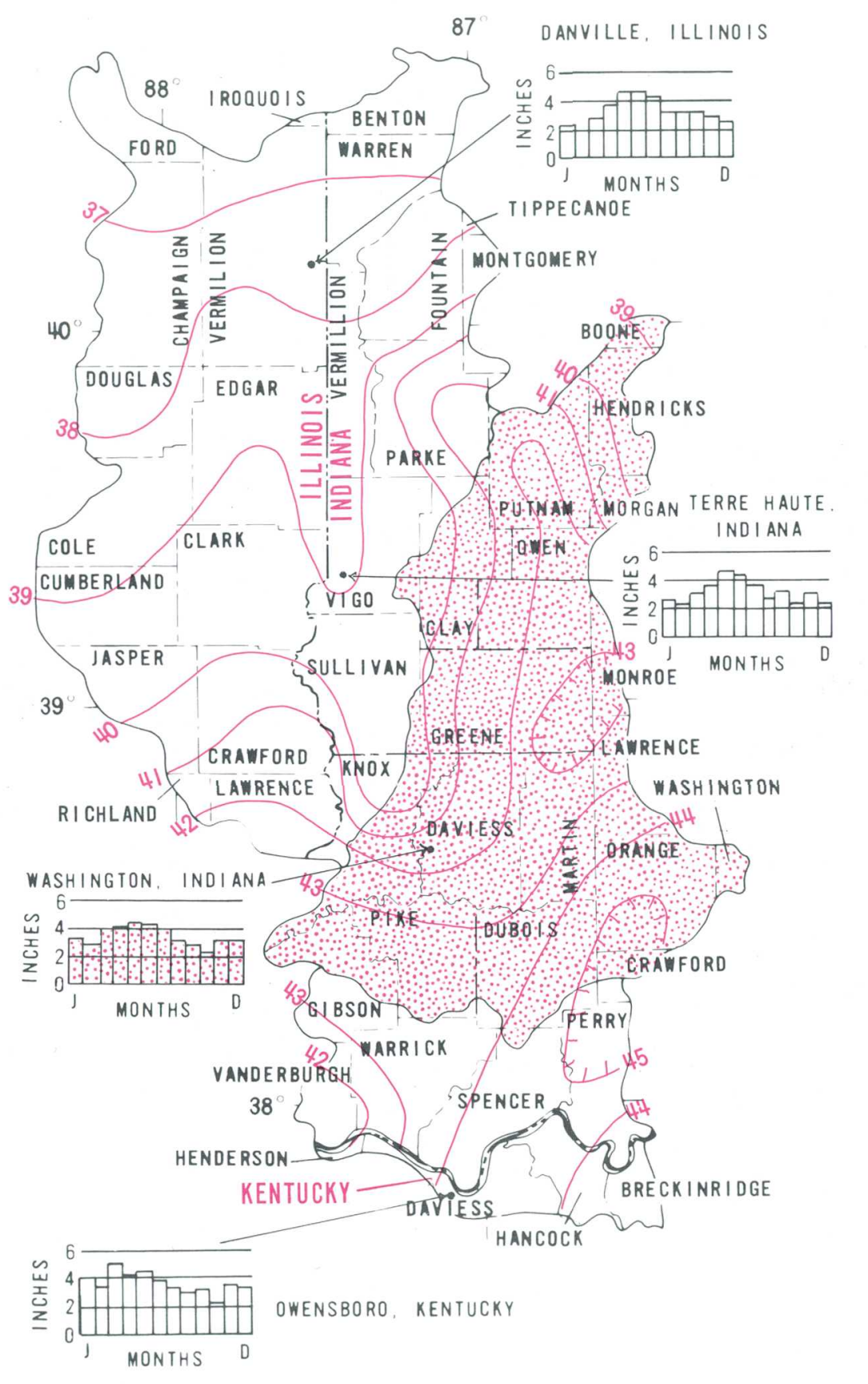

mean annul precipitation and Selected mean monthly temperature. $1941-70$

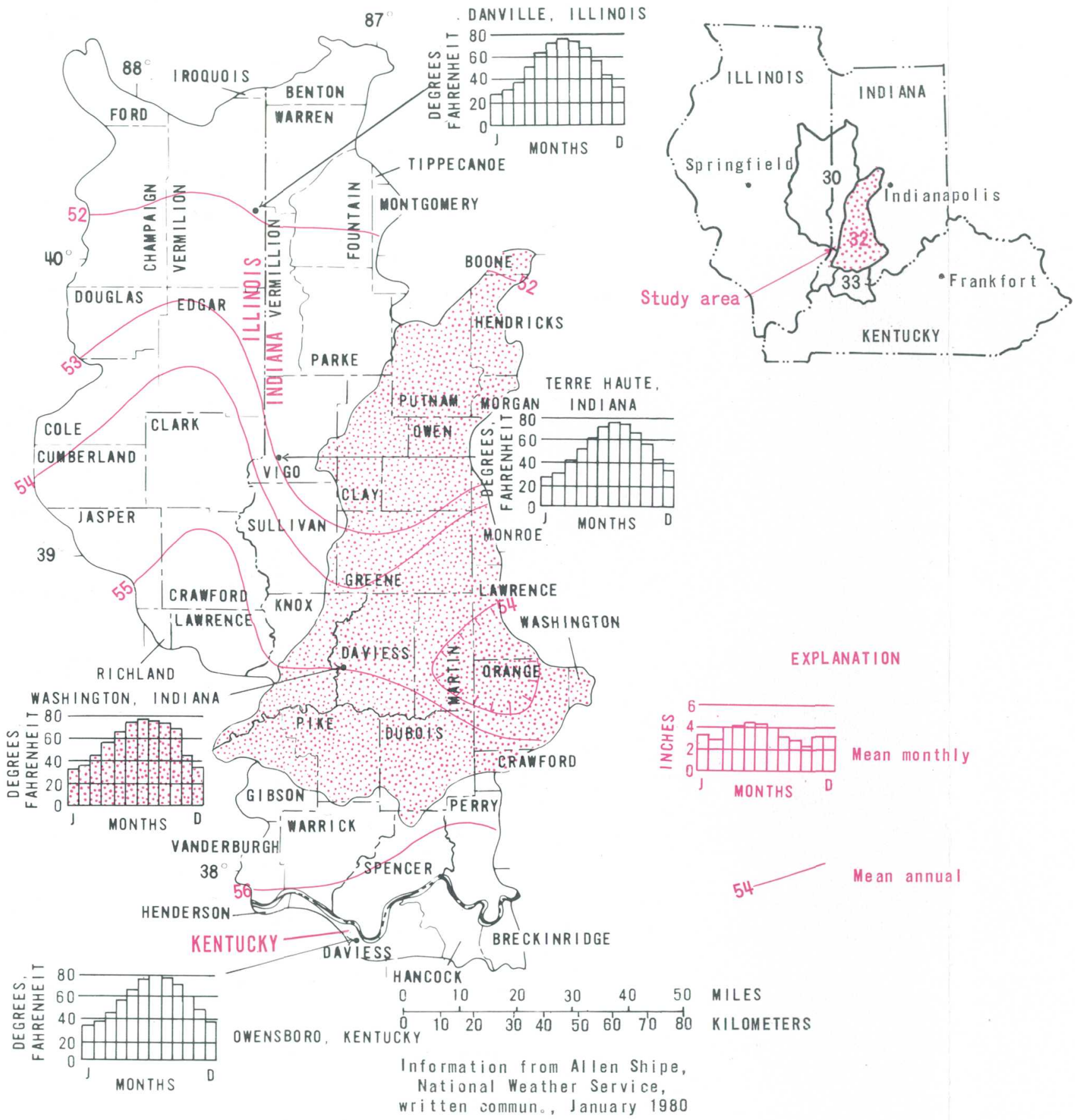

mean anNual precipitation and Selected mean monthly precipitation $1941-70$ 


\title{
1.0 INTRODUCTION
}

1.3 Climate

1.3.2 Rainfall Frequency

\section{RAINFALL-FREQUENCY DATA ARE USED IN PROJECT DESIGN}

\author{
The design of many hydrologic control projects requires precipitation \\ data for various storm frequencies and durations.
}

Frequency analyses of rainfall data are used to compute hydrographs for the design of sewers, culverts, dams, reservoirs, and other hydrologic control projects. Designing hydrologic control projects for maximum runoff is seldom economical. Rather, projects are designed for 10-, 25-, 100-year, or other floods on the basis of a regulation or an economic balance between average damages attributed to occasional floods and the cost of facilities for protection against larger floods.

Except in mountainous terrain, rainfall intensity and frequency variations over short distances are usually small. Thus, precipitation can be mapped for various frequencies and durations. A report by the Indiana Department of Natural Resources (1974) shows precipitation for frequencies of 1 to 100 years and durations of 1 to 24 hours. The adjacent maps (fig. 1.3.2) show amounts of precipitation for frequencies of 10-, 25-, and 100-years for a 24-hour duration. The near straight lines have been extended into northern Kentucky and eastern Illinois. 


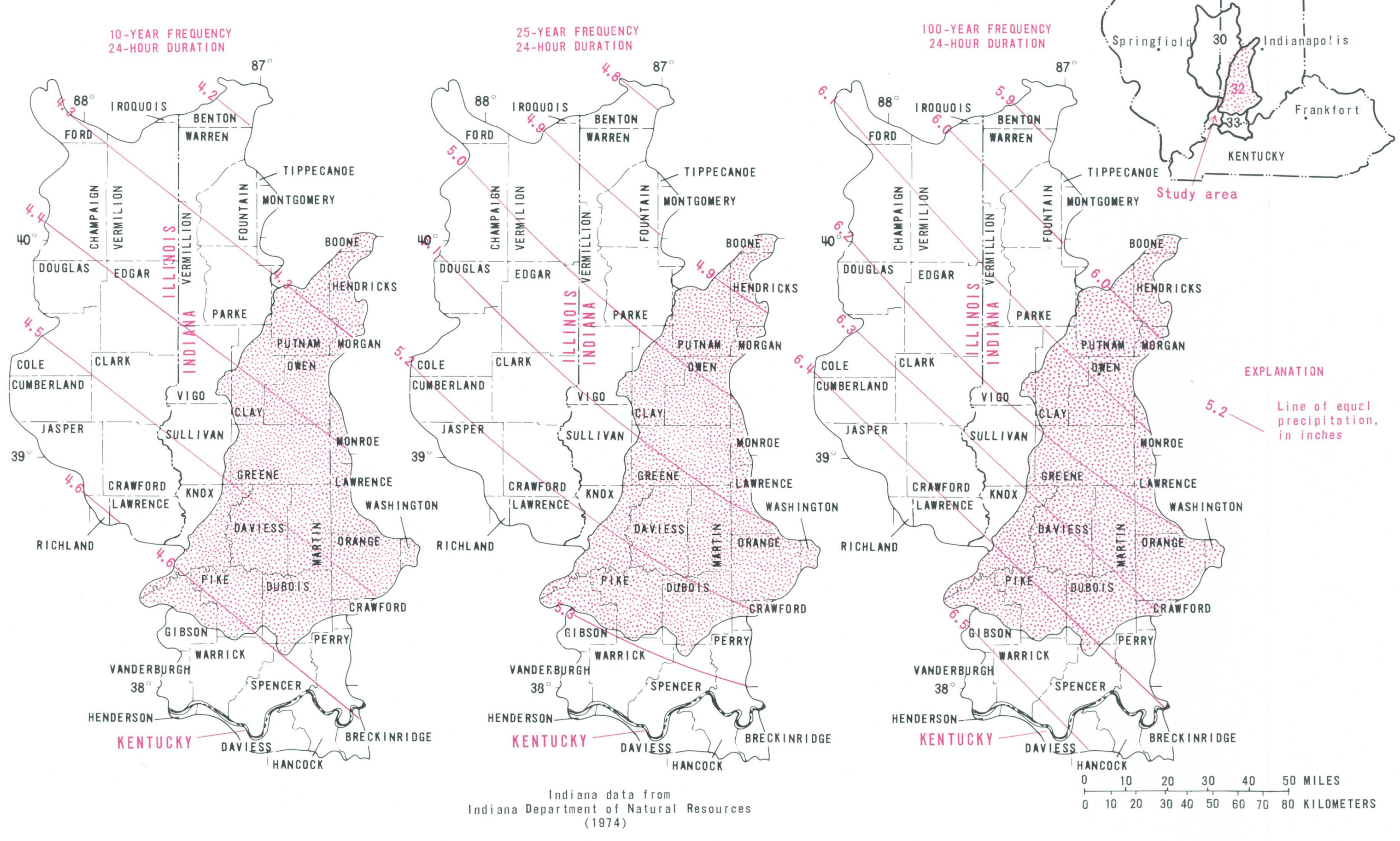

Figure 1.3.2. -- Precipitation magnitude and frequency for 24 -hour duration. 


\title{
1.0 INTRODUCTION \\ 1.4 Drainage Areas and Stream Network
}

\section{FOUR MAJOR DRAINAGES IN AREA 32}

\author{
Four major rivers drain Area 32: the (1) Eel, (2) East Fork White, \\ (3) White, and (4) Patoka Rivers. All drainage flows into the \\ Wabash River at the southwest corner of the study area.
}

Drainage area is useful in analyzing streamflow characteristics for design of hydrologic structures and for evaluating the availability of water. Drainage areas for most named rivers, streams, and ditches have been computed by Hoggatt (1975).
The stream network of Area 32 and the locations where drainage areas are reported are shown on the adjoining map (fig. 1.4). The major streams and computed drainage areas are listed in table 1.4. 
Table 1.4.---Stream and drainage areas

\begin{tabular}{|c|c|c|c|}
\hline \multirow{2}{*}{$\begin{array}{c}\text { Reference } \\
\text { number } \\
\text { 'See fig. } \\
1.4 \text { ) }\end{array}$} & \multirow[b]{2}{*}{ Site name } & \multicolumn{2}{|c|}{ Drainage area $\left(\mathrm{mi}^{2}\right)^{1}$} \\
\hline & & Total area & Area of study \\
\hline 1 & Big Walnut Creek at mouth & 332 & 332 \\
\hline 2 & Mill Creek at mouth & 387 & 387 \\
\hline 3 & Eel River at mouth & 1,208 & 1,208 \\
\hline 4 & White River upstream from Eel River & 3,184 & ${ }^{2} 268$ \\
\hline 5 & $\begin{array}{l}\text { White River upstream from East Fork } \\
\text { White River }\end{array}$ & 5,372 & ${ }^{2} 2,456$ \\
\hline 6 & East Fork White River at mouth & 5,745 & ${ }^{2} 1,057$ \\
\hline 7 & White River at mouth & 11,349 & ${ }^{2} 3,745$ \\
\hline 8 & Patoka River at mouth & 862 & 862 \\
\hline
\end{tabular}

${ }^{1}$ Source: Hoggatt (1975).

Includes only drainage area within Area 32. relunation

(2) Reference point (See table 1.4)

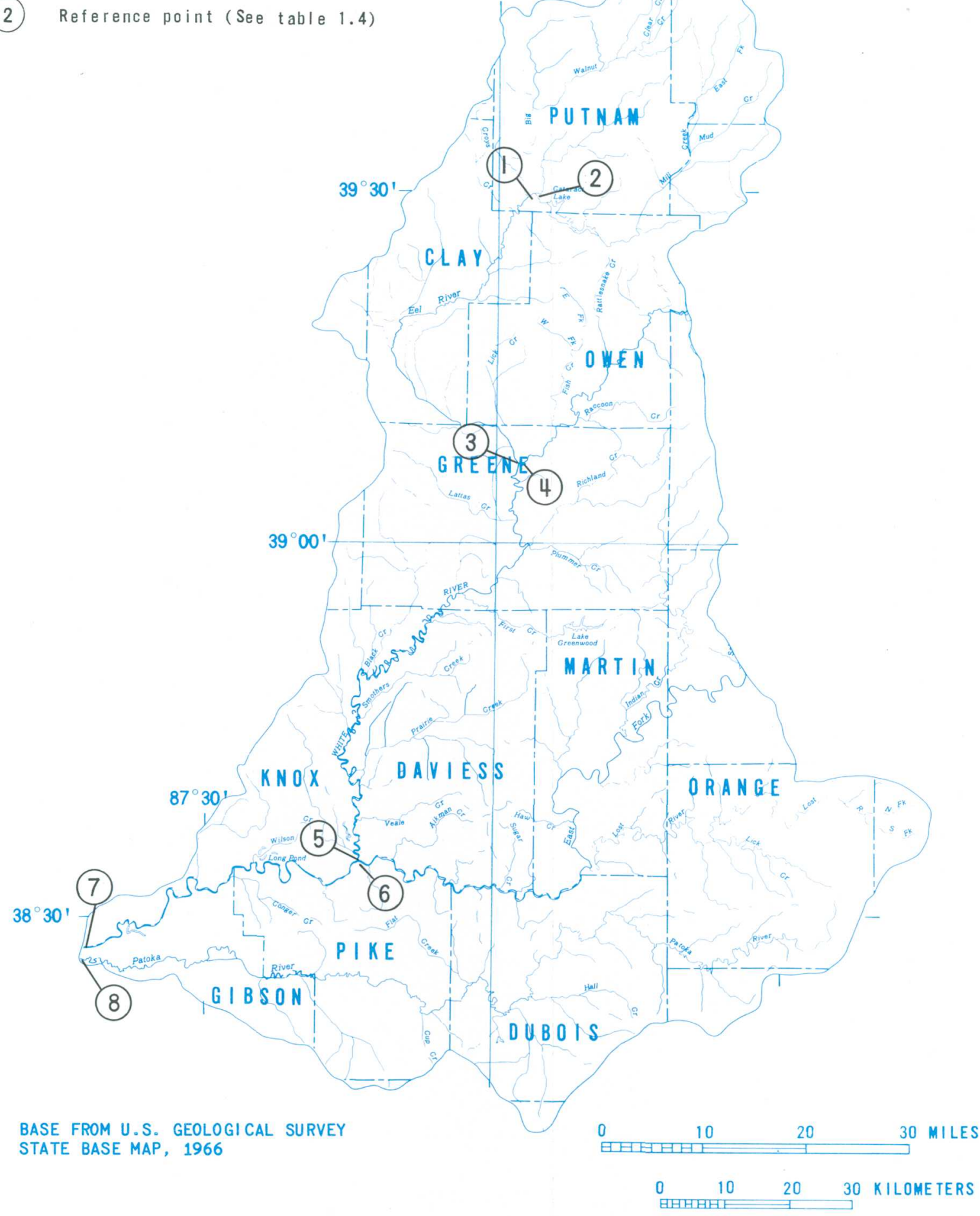

Figure 1.4. -- Stream network. 


\title{
1.0 INTRODUCTION
}

1.5 Geology

1.5.1 Bedrock Geology

\section{BEDROCK COMPOSED OF PENNSYLVANIAN AND MISSISSIPPIAN LIMESTONE, SANDSTONE, AND SHALE, INTERBEDDED WITH PENNSYLVANIAN COALS}

\author{
Bedrock of Pennsylvanian and Mississippian age dips southwest into \\ the Illinois Basin. Coal is mined mainly from eight of \\ the Pennsylvanian coal units.
}

Southwestern Indiana is underlain by rocks of Pennsylvanian age that dip southwest at 25 to 30 feet per mile and of Mississippian age that dip 40 feet per mile into the Illinois Basin, as shown in the geologic section (fig. 1.5.1a) on the facing page. The formations strike generally northwest along the edge of the basin.

Pennsylvanian rocks underlying about twothirds of Area 32 contain Indiana's coal resources. The stratigraphy of the Pennsylvanian formations and coal members is shown in the geologic column on the facing page (fig. 1.5.1b). Areal extent of the Pennsylvanian groups is shown on the geologic map (fig. 1.5.1c). The McLeansboro Group consists of shale, sandstone, and minor amounts of siltstone, limestone, clay, and coal (Shaver and others, 1970, p. 101). The Carbondale Group is a variable sequence of sandstone, shale, limestone, and coal. Most of the commercial coal beds in Indiana are in this group (Shaver and others, 1970, p. 32-33). Shale and sandstone dominate the lithology of the Raccoon Creek Group. Clay, coal, limestone, chert, and sedimentary iron deposits are also present in small amounts. Within Area 32, the Raccoon Creek Group lies unconformably on Mississippian rocks (Shaver and others, 1970, p. 136).

Eight of the Indiana coals are extensively mined. The Springfield Coal Member (V) provides about 49 percent of the total strip-mined coal. Much of this production is from Pike County. Most of the remaining Springfield coal is mined in Warrick County, outside Area 32 (Wangsness and others, in press). Hymera (VI) and Danville (VII) coals account for 23 percent of the total. Upper and Lower Block coals, mainly from Clay and Owen Counties, provide 11 percent. The remaining 17 percent of coal production is from Minshall, Seelyville (III), and Survant (IV) coals (Powell, 1972, p. 6).

Bedrock units of Mississippian age are shown in figures 1.5.1a, 1.5.1b, and 1.5.1c. The upper group, primarily sandstone containing some shale and limestone, crops out in stream valleys in a small southeast part of the study area. The Stephensport Group, which also crops out to the southeast, but over a larger area, consists of cliff-forming limestone, shale, and thin-bedded sandstone. The West Baden Group contains thin-bedded and crossbedded sandstone in shale and some limestone beds (Shaver and others, 1970, p. 173, 189). The Bethel Formation, the oldest formation of this group, contains some thin coal layers (Sunderman, 1968, p. 57). The Blue River Group is mostly carbonate rock containing gypsum, anhydrite, shale, and calcareous sandstone (Shaver and others, 1970, p. 18). Interbedded and interlensed limestones of various compositions make up the Sanders Group (Shaver and others, 1970, p. 160-161). The Borden Group consists primarily of siltstone and shale but contains some discontinuous lenses and facies formed from interbedded limestones (Shaver and others, 1970, p. 21).

The Rockford Limestone, containing some shale, siltstone, and dolomite, is a transitional formation from the Valmeyeran to the Kinderhookian Series (Shaver and others, 1970, p. 141). The Mississippian and Devonian New Albany Shale in the lower part of the Kinderhookian Series crops out in the north tip of the study area. This dark organic shale contains minor amounts of dolomite and dolomitic quartz sandstone (Shaver and others, 1970, p. 115-116). 

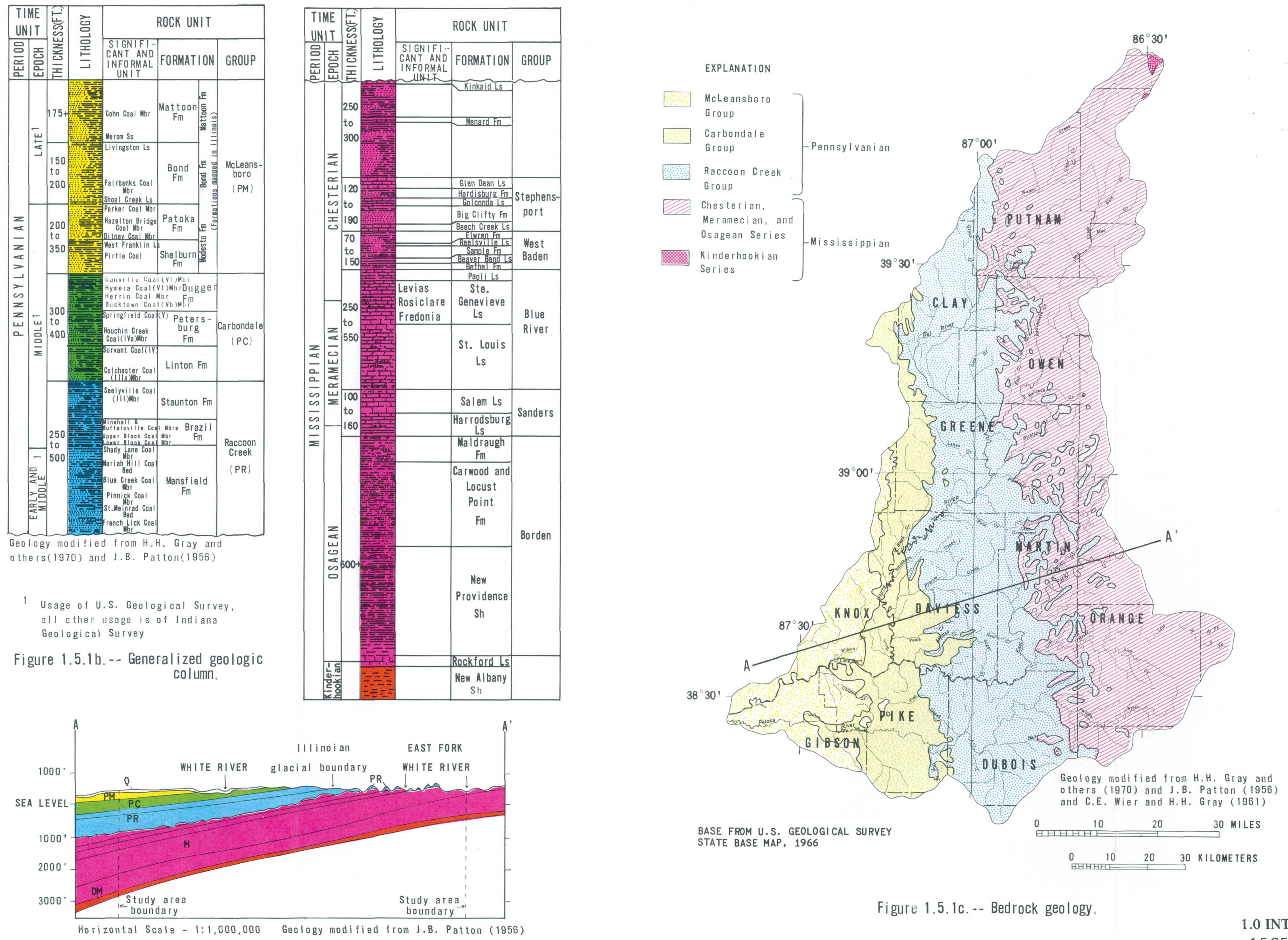

Figure 1.5.1c. -- Bedrock geology. 


\title{
1.0 INTRODUCTION \\ 1.5 Geology \\ 1.5.2 Glacial Geology
}

\section{AT LEAST THREE GLACIAL ADVANCES EXTENDED INTO INDIANA DURING THE PLEISTOCENE EPOCH AND LEFT TWO SHEETS OF TILL}

\author{
The Kansan, IIlinoian, and Wisconsin glacial advances extended into Indiana \\ during the Pleistocene Epoch. The more extensive Illinoian \\ drift covers most of the Kansan drift, and Wisconsin drift \\ covers only a small part of the study area. One-third of \\ the area is unglaciated but is covered by as much as 2 feet \\ of Wisconsin loess. The drift cover affects coal strip- \\ mining operations.
}

\begin{abstract}
At least three glacial advances extended into Indiana during the Pleistocene Epoch. Preglacial surface features were buried under drift left by the glaciers (Wayne, 1966). The Kansan, the first glacial advance into Indiana, was followed by the Illinoian and then the Wisconsin Glaciations. Each glacial advance was followed by a warm interglacial period of active plant growth, weathering, and erosion. The sequence is shown in the adjacent chart of Pleistocene glaciations and interglaciations (fig. 1.5.2a). The drift cover from each glaciation is shown on the glacial geology map (fig. 1.5.2b). About one-third of Area 32 is unglaciated.
\end{abstract}

Kansan drift is not easily recognized because of its position under more recent glacial advances. Only a few good exposures of Kansan drift have been found.

Advance of the Illinoian Glaciation deposited drift farther south than advances of other Pleistocene glaciers. Few moraines were deposited, but many post-glacial lakes and outwash plains were left. All the large valleys of southwestern Indiana were filled with Illinoian lake sediments (Wayne, 1966).

Wisconsin till covers only the north tip of the study area. However, during the Wisconsin Glaciation, winds deposited loess south of the Wisconsin glacial boundary to a maximum thickness of about 2 feet (Gray and Powell, 1965). The unglaciated part of the study area is covered with a layer of loess, and stream valleys are filled with glacial outwash and lake sediments as shown on the adjacent map (fig. 1.5.2b).

Thickness of drift varies throughout the study area. Thickness north of the Wisconsin boundary ranges from 100 to 200 feet. In the remaining area, covered by Illinoian drift, thickness ranges from 50 to 100 feet, sometimes thinning toward the Illinoian boundary to a range from 25 to 50 feet (Henry $\mathrm{H}$. Gray, written commun., April, 1980). The unglaciated part is not covered with drift.

Strip mining is easier in glacial drift than in bedrock because the unconsolidated drift is easier to excavate than bedrock. Even with the additional overburden added by the drift, the leveled glacial surface provides a more uniform depth to coal. Drift cover can cause problems, however. Many sand and gravel lenses within the till contain large amounts of water. Drift slumps and does not provide a stable highwall. Estimates of coal reserves can be miscalculated where bedrock valleys that have cut through the coal are obscured by drift (Powell, 1972, p. 4). 


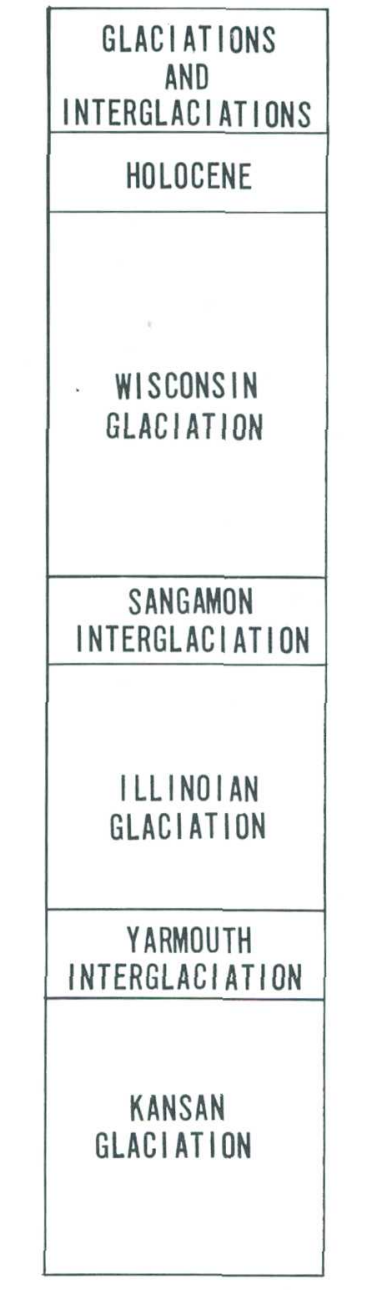

Geology modified from W. J. Wayne (1966, p.28)

Figure 1.5.2a. -- Pleistocene stages in Indiana.

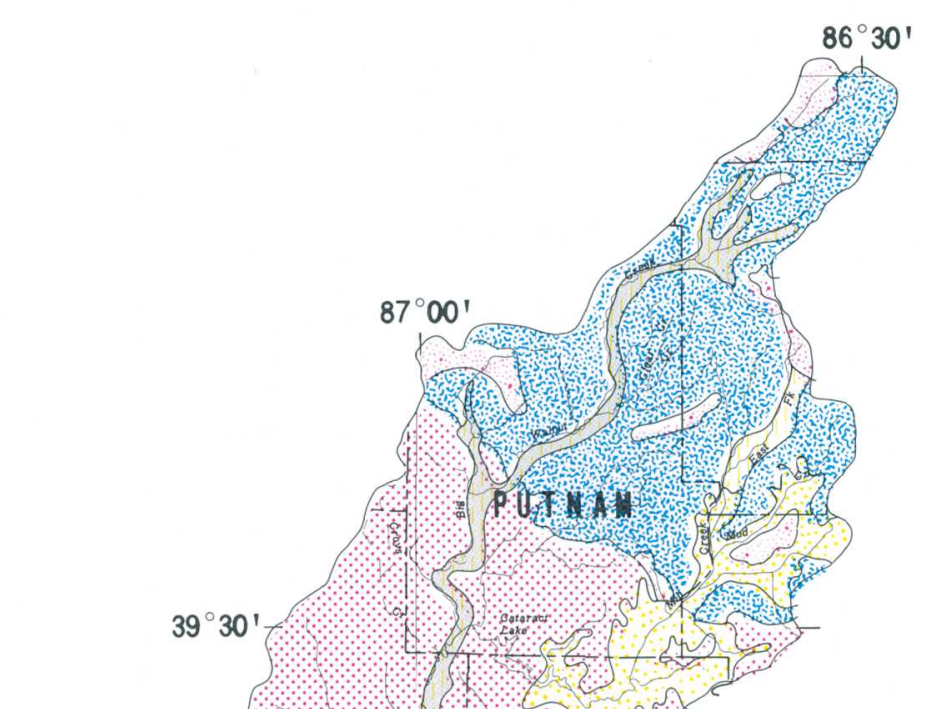

EXPLANATION

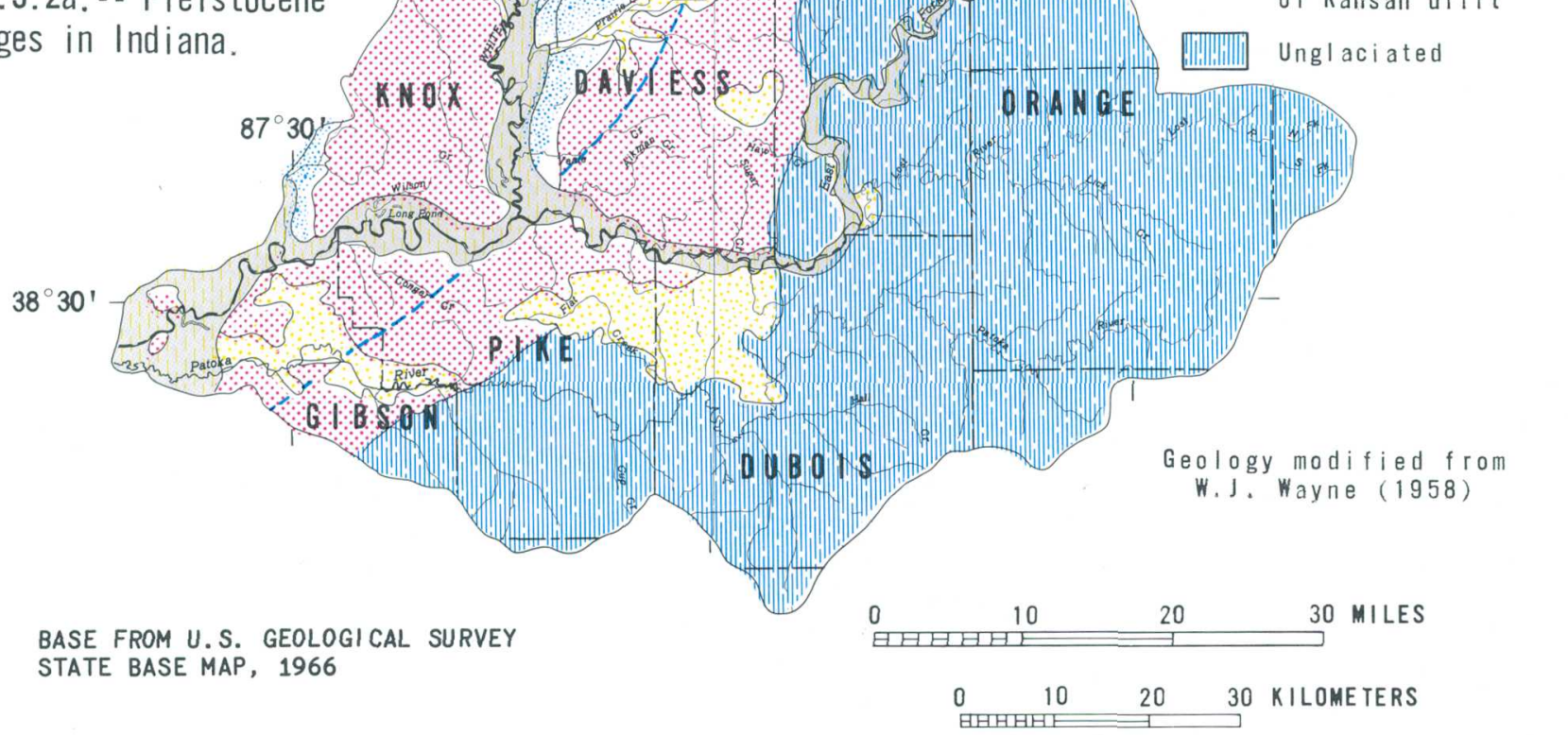

Figure 1.5.2b.-- Glacial geology. 


\title{
1.0 INTRODUCTION \\ 1.6 Soil Associations
}

\section{SOIL TYPE AND LAND SLOPE VARY WIDELY}

\author{
Area 32 contains 64 soil types. The surface horizons of many of the soils \\ are light-colored silty loams or silty clay loams underlain by clay \\ loams and silty clays. Poor to well-drained soils are found on slopes \\ generally ranging from nearly level terraces and plains to slopes \\ greater than 35 percent.
}

The soil associations within Area 32 are shown on the adjoining map (fig. 1.6), and descriptions of the associations are listed in Appendix 1. Information is from an Indiana soils association map published by the U.S. Soil Conservation Service (1977b).
More detailed information is available in county soil surveys that are also published by the Soil Conservation Service. Some of these reports are referenced in section 6.2. 
A3 Sloan-Ross-Vincennes-Zipp

D2 Patton-Lyles-Henshaw

D3 Zipp-Markland-McGary

I4 Reesville-Ragsdale

I5 Iva-Vigo

L4 Miami-Crosby-Brookston

L5 Miami-Hennepin-Crosb

L7 Russel-Hennepin-Fincastle

01 Hasmer

Q2 Crider-Hagerstown-Bedford

C1 Rensselar-Darroch-Whitake

C3 Lyles-Ayrshire-Princeton

G Princeton-Bloomfield-Ayrshire

I3 Fincastle-Ragsdale

02 Zanesville-Wellston-Tilsi

03 Cincinnati-Vigo-Ava

P Wellston-Zanesville-Berks

Q3 Crider-Baxter-Corydon

M1 Markham-Elliott-Pewamo

A1 Genesee-Eel-Shoaks

A2 Fox-Genesee-Eel

A4 Stendal-Haymond-Wakeland-Nolin

E5 Parke-Negle

$H$ Alford

J3 Crosby-Brookston

L6 Miami-Russel-Fincste-Ragade

N1 Bartle-Peoga-Dubois

Q1 Crider-Bedford-Lawren

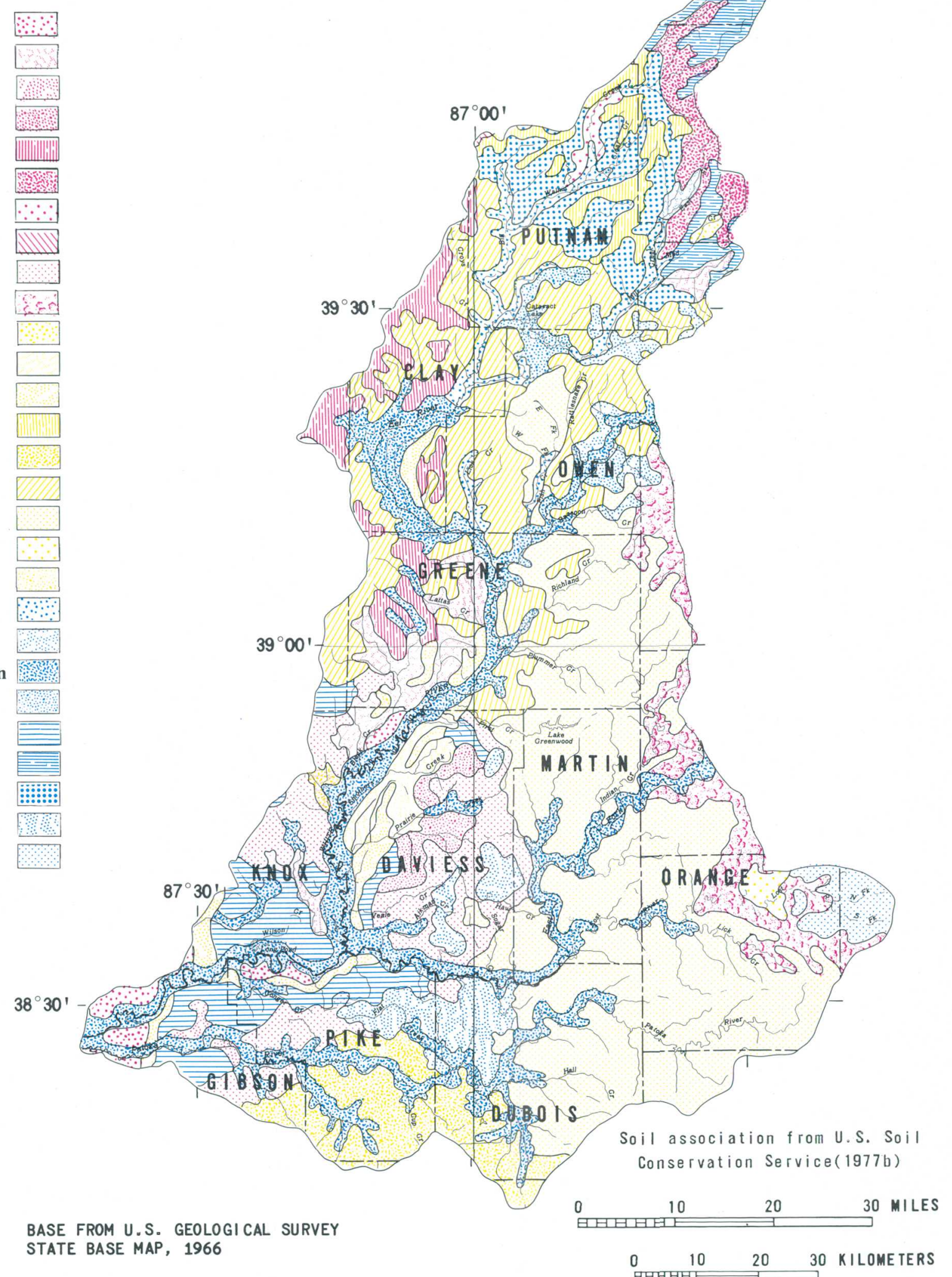

Figure 1.6.-- Soil associations. 


\title{
1.0 INTRODUCTION \\ 1.7 Coal Mining
}

\section{COAL PRODUCTION AND ESTIMATED RESERVES}

\author{
Indiana coal production totaled nearly 24 million tons in $1978 .^{1}$ \\ Seventy-four percent of this coal was mined in the counties represented \\ in Area 32. As of 1978, more than 1 billion tons of coal \\ had been mined from these same counties. Reserves are \\ estimated to total more than 12 billion tons.
}

\begin{abstract}
According to Carter and others (1974, p. III-6), commercial coal mines were opened in Indiana in 1812. Small strip-mine operations using horse-drawn scrapers worked outcrop areas overlain by only a few feet of loose, unconsolidated overburden. In 1840, Indiana strip mines produced 9,682 tons of coal. As production demands increased, the mining industry turned to underground mines. By 1860 , the industry was producing 100,000 tons of coal per year. By the late 1930's, the development of excavating equipment that could dig coal at a faster rate than the older equipment and the increased efficiency of explosives had caused a resurgence of surface mining. More than 50 percent of the coal produced came from surface mines. In 1978, about 98 percent of the coal produced came from surface mines. There were only four underground mines in 1978 (Indiana Bureau of Mines and Mining, 1979) compared with about 500 in 1920 (Carter and others, 1974, p. III-7).
\end{abstract}

In Indiana, there are nine major coal seams in Pennyslvanian rock (Carter and others, 1974, p. III-
10). The average thickness of the seams is 4.4 feet. Nearly half of the coal produced in Indiana is from Coal V (Springfield Coal Member). The coals in Indiana are generally high in sulfur and are highly volatile bituminous types B or C coals.

Estimates of coal reserves are subject to revision, owing to advances in mining technology. Carter and others (1974, p. III-11) and Wier (1973, p. 21) summarized the coal production figures through 1970. Data for 1971-78 are from annual reports of the Indiana Bureau of Mines and Mining (1972-79). Maps showing locations of active surface and underground coal mines in some of the counties in southwestern Indiana are available from the Indiana Department of Natural Resources (1980). Maps showing locations of areas strip mined for coal (Powell, 1972; Powell, 1976) and of active mines (Powell, 1977) are also available. Coal-production figures and estimates of coal reserves by county for Area 32 from 1812 through 1978 are listed in table 1.7.

${ }^{1}$ Indiana Bureau of Mines and Mining, 1978. 
Table 1.7.--Coal production and estimates of reserves

[Sources of data: Estimates of reserves, from Donald L. Eggart, Indiana Geological Survey, written commun., March 1980; Coal production, from Carter and others, 1974, III-II; Wier, 1973, p. 21; and Indiana Bureau of Mines and Mining, 1972-79]

\begin{tabular}{|c|c|c|c|c|}
\hline \multirow{3}{*}{ Counties $^{2}$} & \multirow{3}{*}{$\begin{array}{c}\text { Coal production } \\
\text { in Indiana } \\
1812-1978 \\
\text { (tons) }\end{array}$} & \multicolumn{3}{|c|}{ Estimates of recoverable reserves ${ }^{1}$} \\
\hline & & $\begin{array}{c}\text { Strippable } \\
\text { reserves }\end{array}$ & $\begin{array}{c}\text { Underground } \\
\text { reserves }\end{array}$ & \multirow[t]{2}{*}{ Total } \\
\hline & & \multicolumn{2}{|c|}{ (thousand tons) } & \\
\hline $\begin{array}{l}\text { Clay } \\
\text { Daviess } \\
\text { Dubois } \\
\text { Gibson } \\
\text { Greene } \\
\text { Knox } \\
\text { Martin } \\
\text { Owen } \\
\text { Pike } \\
\text { Sullivan } \\
\text { Vigo }\end{array}$ & $\begin{array}{r}100,960,095 \\
13,495,235 \\
992,304 \\
45,393,580 \\
135,822,017 \\
117,599,560 \\
142,115 \\
4,181,088 \\
152,387,718 \\
193,846,662 \\
247,820,597\end{array}$ & $\begin{array}{r}307,872 \\
136,260 \\
3,963 \\
0 \\
191,038 \\
141,330 \\
82,698 \\
50,673 \\
188,469 \\
273,484 \\
253,780\end{array}$ & $\begin{array}{r}252,366 \\
119,502 \\
3,978 \\
2,231,226 \\
228,369 \\
2,241,269 \\
11 \\
0 \\
369,699 \\
3,482,223 \\
1,448,432\end{array}$ & $\begin{array}{r}560,238 \\
255,762 \\
7,941 \\
2,231,226 \\
419,407 \\
2,382,599 \\
82,709 \\
50,673 \\
558,168 \\
3,755,707 \\
1,702,212\end{array}$ \\
\hline
\end{tabular}

${ }^{1}$ These figures are subject to revision as mining techniques change. The current figures are based on removing 90 feet of overburden. Present technology allows for removal of 120 feet of overburden; with some equipment, as much as 150 feet of overburden can be removed. As technology and equipment are improved, thickness of overburden removed and, therefore, the amount of strippable reserves will increase. Also, the techniques for calculating coal reserves are improving, and the number and the depth of test wells are increasing.

${ }^{2}$ Figures listed in the table represent coal production by county, and, therefore, should not be totaled to represent production within the study area. Several counties are represented within more than one study area, and their production figures appear in other study area reports. 


\title{
1.0 INTRODUCTION \\ 1.8 Land Use and Prime Farmland
}

\section{MOST OF LAND IS FARMED OR FORESTED}

\author{
The greatest use of land within Area 32 is for agriculture (62 percent), \\ followed by forested lands (29 percent). Land affected by mining \\ activities amounts to less than 1 percent of the total land area. \\ Sullivan County has the largest area affected by mining, 10,676 \\ acres, about one-third of the area mined.
}

General land-use categories by area and percent of total area for the 18 counties discussed in this report are listed in table 1.8. Land-use categories are described in the list that follows.

Agriculture--row crop, pasture, small grains, and barren rural lands.

Urban--residential, commercial, industrial, institutions, and recreational.

Forested--commercial forest and wooded farm lots.

Water--lakes, ponds, and rivers.

Wetland--marsh or bog areas.

Mined--surface area affected by strip or under ground mines.

Other--miscellaneous land uses not generally categorized.
Land-use maps are available for most of the counties in Indiana through the Indiana State Board of Health, Stream Pollution Control Board (1980), at a scale of $1: 250,000$.

Limits on the mining of prime farmland (land best suited for producing food, fiber, forage, and oil seed crops) are given in paragraph 779.27 of the Surface Mining Control and Reclamation Act of 1977. Areas of prime farmland are shown on the adjoining map (fig. 1.8). 


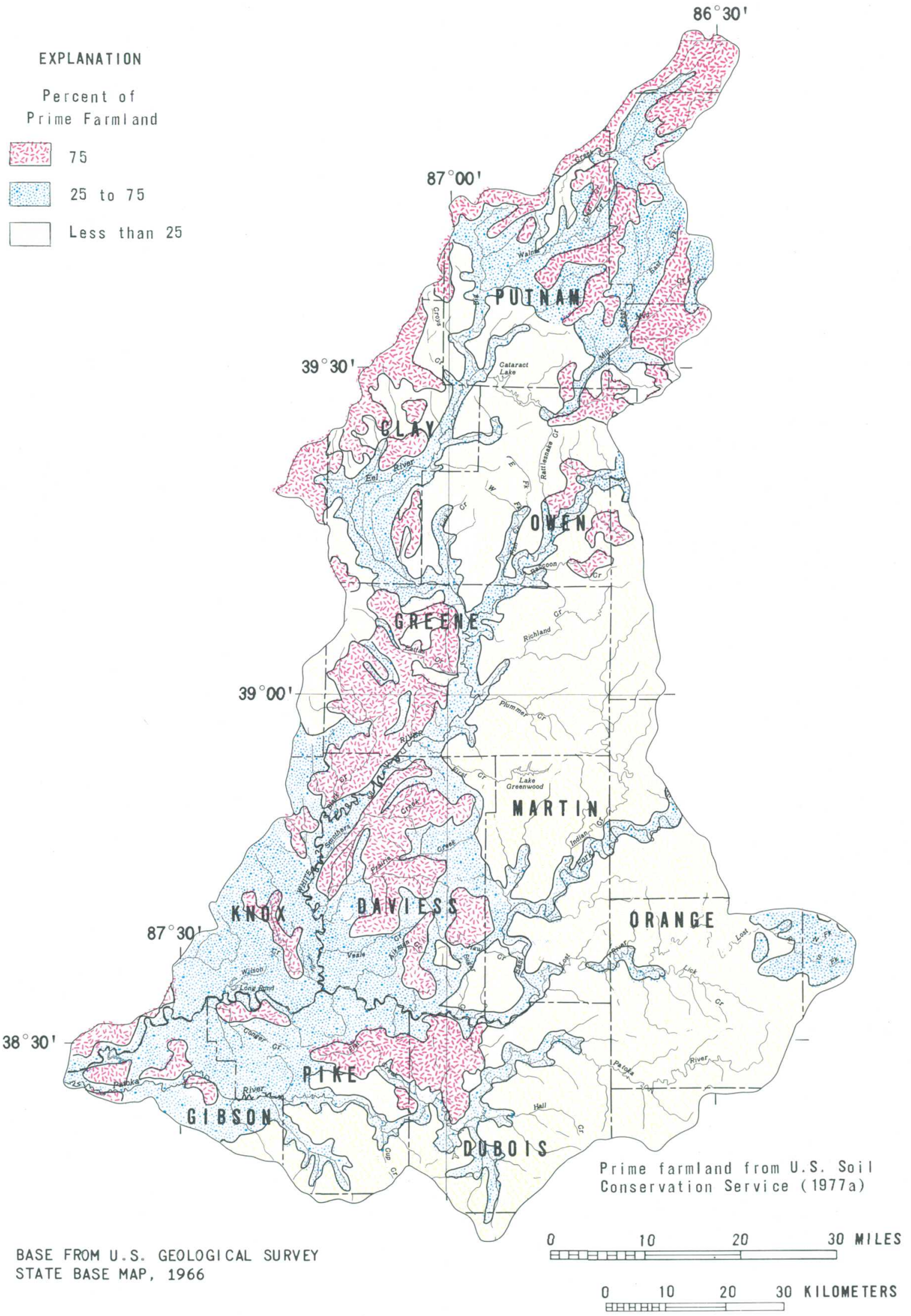

Figure 1.8. .- Prime farmland.

\begin{tabular}{|c|c|c|c|c|c|c|c|c|}
\hline County & $\begin{array}{l}\text { Agri- } \\
\text { culture } \\
\end{array}$ & Urban & Forested & Water & $\begin{array}{l}\text { Wet- } \\
\text { land }\end{array}$ & Mined & Other & $\begin{array}{l}\text { Total } \\
\text { (acres) }\end{array}$ \\
\hline Clay ${ }^{1}$ & $\frac{146,346}{62.8}$ & $\frac{9,621}{4.1}$ & $\frac{72,218}{31.1}$ & $\frac{769}{0.3}$ & $\begin{array}{l}0 \\
0\end{array}$ & $\frac{4,007}{1.7}$ & & 232,961 \\
\hline Crawford $^{2}$ & $\frac{76,744}{38.4}$ & $\frac{10,783}{5.4}$ & $\frac{108,813}{.54 .5}$ & $\frac{2,357}{1.2}$ & 9 & $\frac{1,047}{0.5}$ & $\begin{array}{l}90 \\
--\end{array}$ & 199,743 \\
\hline Daviess² & $\frac{214,100}{77.8}$ & $\frac{20,466}{7.4}$ & $\frac{29,851}{10.8}$ & $\frac{2,694}{1.1}$ & $\begin{array}{l}55 \\
--\end{array}$ & $-\frac{201}{0.1}$ & $\frac{7,833}{2.8}$ & 275,200 \\
\hline Dubois² & $\frac{175,283}{63.2}$ & $\frac{10,405}{3.8}$ & $\frac{84,251}{30.4}$ & $\frac{3,969}{1.4}$ & $\frac{203}{0.1}$ & $\frac{347}{0.1}$ & $\frac{2,663}{1}$ & 277,121 \\
\hline Gibson $2,3^{2}$ & $\frac{\frac{222,722}{69.8}}{6.8}$ & $\frac{9,570}{3.0}$ & $\frac{78,443}{24.6}$ & $\frac{3,103}{1}$ & $\frac{2,140}{0.7}$ & $\frac{177}{---}$ & $\frac{2,757}{0.9}$ & 318,912 \\
\hline$G_{\text {Greene }}^{2}$ & $\frac{217,150}{61.8}$ & $\frac{14,586}{4.2}$ & $\frac{106,900}{30.4}$ & $\frac{1,791}{0.5}$ & 0 & $-\frac{248}{0.1}$ & $\frac{10,685}{3.0}$ & 351,360 \\
\hline Hendricks & $\frac{227,949}{85.4}$ & $\frac{4,652}{1.7}$ & $\frac{19,091}{7 \cdot 2}$ & $\begin{array}{r}\text { no } \\
\text { inform }\end{array}$ & ation & 0 & $\frac{15,188}{5.7}$ & 266,880 \\
\hline Knox ${ }^{2}$ & $\frac{266,500}{80.7}$ & $\frac{15,814}{4.8}$ & $\frac{38,000}{11.5}$ & $\frac{2,091}{0.6}$ & $\begin{array}{l}30 \\
--\end{array}$ & $\frac{311}{0.1}$ & $\frac{7,494}{2.3}$ & 330,240 \\
\hline Lawrence ${ }^{2}$ & $\frac{144,500}{45.5}$ & $\frac{43,789}{13.8}$ & $\frac{120,600}{38}$ & $\frac{2,088}{0.6}$ & $\begin{array}{l}70 \\
--\end{array}$ & $-\frac{730}{0.2}$ & $\frac{5,983}{1.9}$ & 317,760 \\
\hline $\operatorname{Martin}^{2}$ & $\frac{74,460}{33.8}$ & $\frac{10,015}{4.5}$ & $\frac{67,800}{30.7}$ & $\frac{2,375}{1.1}$ & $\frac{10}{--}$ & $-\frac{700}{0.3}$ & $\frac{65,440}{29.6}$ & 220,800 \\
\hline Monroe $^{2}$ & $\frac{113,901}{44.1}$ & $\frac{\frac{23,654}{9.2}}{9.2}$ & $\frac{99,536}{38.6}$ & $\frac{14,200}{5.5}$ & $\frac{1,725}{0.7}$ & $-\frac{552}{0.2}$ & $\frac{4,350}{1.7}$ & 257,918 \\
\hline Morgan $^{4}$ & $\frac{165,817}{63.9}$ & $\frac{2,694}{1.0}$ & $\frac{80,301}{30.9}$ & $\begin{array}{r}\text { no } \\
\text { inform }\end{array}$ & & 0 & $\frac{11,028}{4.2}$ & 259,840 \\
\hline Owen² & $\frac{117,312}{48.1}$ & $\frac{5,010}{2.1}$ & $\frac{116,580}{47.8}$ & $\frac{1,970}{0.8}$ & $\frac{985}{0.4}$ & $\frac{2,073}{0.8}$ & $\frac{140}{---}$ & 244,070 \\
\hline Orange $^{2}$ & $\frac{125,730}{48.5}$ & $\frac{12,368}{4.8}$ & $\frac{114,668}{44.2}$ & $\frac{5,500}{2.1}$ & $\begin{array}{l}48 \\
--\end{array}$ & $\frac{148}{0.1}$ & $\frac{673}{0.3}$ & 259,135 \\
\hline $\mathrm{Pike}^{2,3}$ & $\frac{76,934}{35.9}$ & $\frac{15,356}{7.2}$ & $\frac{116,285}{54.2}$ & $\frac{395}{0.2}$ & $\frac{706}{0.3}$ & $\frac{3,792}{1.8}$ & $\frac{935}{0.4}$ & 214,403 \\
\hline Putnam 1 & $\frac{213,438}{68.3}$ & $\frac{1,155}{0.4}$ & $\frac{95,476}{30.6}$ & $\frac{1,655}{0.5}$ & 0 & $-\frac{593}{0.2}$ & $\frac{0}{0}$ & 312,317 \\
\hline Sullivan & $\frac{245,144}{83.8}$ & $\frac{4,389}{1.5}$ & $\frac{29,367}{10}$ & $\frac{2,924}{0.1}$ & 0 & $\frac{10,676}{3.6}$ & $\frac{0}{0}$ & 292,500 \\
\hline Vigo ${ }^{2}$ & $\frac{191,816}{72.2}$ & $\frac{22,601}{8.5}$ & $\frac{42,151}{15.9}$ & $\frac{3,055}{1.2}$ & $\begin{array}{l}0 \\
0\end{array}$ & $\frac{5,976}{2.2}$ & 0 & 265,599 \\
\hline Total & $\frac{\beta, 015,846}{61.7}$ & $\frac{236,928}{4.8}$ & $\frac{1,420,331}{29.1}$ & $\frac{50,936}{1}$ & $\frac{5,981}{---}$ & $\frac{31,578}{0.6}$ & $\frac{35,259}{2.8}$ & $4,896,759$ \\
\hline
\end{tabular}

IMark Blade, West Central Indiana Economic Development District, Inc., written

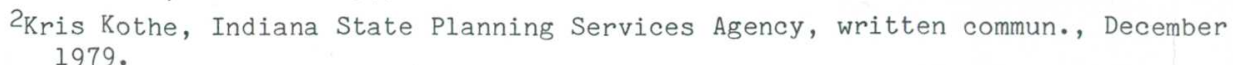

3Marcia A. Werling, Southwest Indiana and Kentucky Regional Council of Governments,

4Doug Winings, Indiana Heartland Coordinating Commission, written commun.

1.0 INTRODUCTION

1.8 LAND USE AND PRIME FARMLAND 


\title{
2.0 SURFACE WATER \\ 2.1 Gaging Stations
}

\section{DESCRIPTION OF U.S. GEOLOGICAL SURVEY GAGING STATIONS}

\author{
Discharge data have been collected at 24 continuous-record stations, \\ 16 low-flow stations, and 14 crest-stage partial-record stations.
}

Discharge data analyzed for this report have been collected at 24 continuous-record stations, 16 low-flow stations, 14 crest-stage partial-record stations, and at several miscéllaneous measurement sites. Data from miscellaneous measurements are also available from the Geological Survey office in Indianapolis.

Length and type of records available at gaging stations vary. The gaging stations on the Patoka River near Princeton, Jasper, and Ellsworth have been controlled by the Patoka Reservoir since February 1978. The analyses for these stations were computed for the period of record ending with the 1977 water year, representing unregulated conditions. Lengths of record for the gaging stations on the White River upstream from Petersburg and Big Walnut Creek at Greencastle are insufficient for analysis.

The gaging stations on the Eel River at Bowling Green and Mill Creek near Manhattan recorded two periods of hydrologic record. Before July 1953, the flow was unregulated. From July 1953 to the present (1980), the flow was regulated by the Cagles Mill Lake Reservoir. Discharge data from the times that the stations were established through the 1952 water year and from the 1954 through 1979 water years were analyzed for this report.

Gaging stations within the study area are listed in table 2.1, and their locations are shown on the adjoining map (fig. 2.1).

Table 2.1.--Gaging stations

\begin{tabular}{|c|c|c|c|c|}
\hline Station name & $\begin{array}{l}\text { Station } \\
\text { number }\end{array}$ & $\begin{array}{l}\text { Drainage } \\
\text { area }\left(\mathrm{mi}^{2}\right)\end{array}$ & $\begin{array}{l}\text { Period of } \\
\text { record }\end{array}$ & $\begin{array}{l}\text { Station } \\
\text { type }\end{array}$ \\
\hline $\begin{array}{l}\text { South Fork Patoka } \\
\text { River nr Spurgeon }\end{array}$ & 03376350 & 42.8 & 1922 to present & Continuous \\
\hline $\begin{array}{l}\text { Hall Creek nr } \\
\text { St. Anthony }\end{array}$ & 03375800 & 21.8 & 1970 to present & Do. \\
\hline $\begin{array}{l}\text { Patoka River nr } \\
\text { Princeton }\end{array}$ & 03376500 & 822 & 1934 to present & Do. \\
\hline $\begin{array}{l}\text { Flat Creek nr } \\
\text { Otwell }\end{array}$ & 03376260 & 21.3 & 1964 to present & Do. \\
\hline $\begin{array}{l}\text { Patoka River at } \\
\text { Jasper }\end{array}$ & 03375500 & 262 & 1947 to present & Do. \\
\hline $\begin{array}{l}\text { Patoka River nr } \\
\text { Ellsworth }\end{array}$ & 03374500 & 171 & 1961 to present & Do. \\
\hline $\begin{array}{l}\text { Patoka Lake nr } \\
\text { Cuzco }\end{array}$ & 03374498 & 168 & 1978 to present & Do. \\
\hline $\begin{array}{l}\text { Patoka River } \mathrm{nr} \\
\text { Hardinsburg }\end{array}$ & 03374455 & 12.8 & 1968 to present & Do. \\
\hline $\begin{array}{l}\text { White River at } \\
\text { Petersburg }\end{array}$ & 03374000 & 11,125 & 1927 to present & Do. \\
\hline $\begin{array}{l}\text { White River above } \\
\text { Petersburg }\end{array}$ & 03373980 & 11,123 & 1976 to present & Do. \\
\hline $\begin{array}{l}\text { Lost River nr } \\
\text { West Baden Springs }\end{array}$ & 03373700 & 287 & 1964 to present & Do. \\
\hline $\begin{array}{l}\text { East Fork White River } \\
\text { at Shoals }\end{array}$ & 03373500 & 4,927 & $\begin{array}{l}1903 \text { to } 1906 \\
1908 \text { to } 1916 \\
1923 \text { to present }\end{array}$ & Do. \\
\hline $\begin{array}{l}\text { White River at } \\
\text { Newberry }\end{array}$ & 03360500 & 4,688 & 1928 to present & Do. \\
\hline $\begin{array}{l}\text { Eel River at } \\
\text { Bowling Green }\end{array}$ & 03360000 & 830 & 1931 to present & Do. \\
\hline $\begin{array}{l}\text { Mill Greek nr } \\
\text { Manhatian }\end{array}$ & 03359000 & 294 & 1938 to present & Do. \\
\hline $\begin{array}{l}\text { Cagles Mill Lake } \\
\text { nr Manhattan }\end{array}$ & 03358900 & 293 & 1953 to present & Do. \\
\hline $\begin{array}{l}\text { Mill Creek nr } \\
\text { Cataract }\end{array}$ & 03358000 & 245 & 1949 to present & Do. \\
\hline $\begin{array}{l}\text { Big Walnut Creek } \\
\text { nr Reelsville }\end{array}$ & 03357500 & 326 & 1949 to present & Do. \\
\hline $\begin{array}{l}\text { Big Walnut Creek at } \\
\text { Greencastle }\end{array}$ & 03357420 & 216 & 1974 to present & Do. \\
\hline $\begin{array}{l}\text { Plum Creek nr } \\
\text { Bainbridge }\end{array}$ & 03357350 & 3.0 & 1969 to present & Do. \\
\hline
\end{tabular}




\begin{tabular}{|c|c|c|c|c|}
\hline Station name & $\begin{array}{l}\text { Station } \\
\text { number }\end{array}$ & $\begin{array}{l}\text { Drainage } \\
\text { area }\left(\mathrm{mi}^{2}\right)\end{array}$ & $\begin{array}{l}\text { Period of } \\
\text { record }\end{array}$ & $\begin{array}{l}\text { Station } \\
\text { type }\end{array}$ \\
\hline White River at & 03360500 & 4,688 & 1928 to present & Continuous \\
\hline $\begin{array}{l}\text { River at } \\
\text { River }\end{array}$ & 03360000 & 830 & 1931 to present & Do. \\
\hline 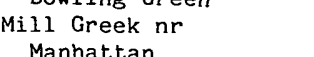 & 03359000 & 294 & 1938 to present & Do. \\
\hline 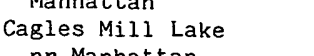 & 03358900 & 293 & 1953 to present & Do. \\
\hline $\begin{array}{l}\text { Mill creek } \mathrm{nr} \\
\text { Mil }\end{array}$ & 03358000 & 245 & 1949 to present & Do. \\
\hline $\begin{array}{l}\text { Big Walnut Creek } \\
\text { Big hal }\end{array}$ & 03357500 & 326 & 1949 to present & Do. \\
\hline Big wannut Creek at & 03357420 & 216 & 1974 to present & Do. \\
\hline $\begin{array}{l}\text { Plum Creek nr } \\
\text { Pluter }\end{array}$ & 03357350 & 3.0 & 1969 to present & Do. \\
\hline $\begin{array}{l}\text { Whinnorivge } \\
\text { White River at }\end{array}$ & 03357000 & 2,988 & 1925 to 1971 & Do. \\
\hline 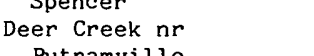 & 03359500 & 59 & 1954 to 1965 & Do. \\
\hline $\begin{array}{l}\text { Puttanamviliee } \\
\text { Patoka River } \mathrm{nr}\end{array}$ & 03376000 & 342 & 1945 to 1947 & Low flow \\
\hline $\begin{array}{l}\text { Jasper } \\
\text { Birch Creek nr }\end{array}$ & 03360050 & 40 & 1974 to 1978 & Do. \\
\hline $\begin{array}{l}\text { Assboro } \\
\text { Richland Creek nr } \\
\text {, }\end{array}$ & 03360300 & 95 & 1960,1965 & Do. \\
\hline 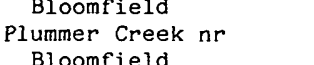 & 03360225 & 67 & $\begin{array}{l}\text { to } 1967 \\
1968 \text { to } 1973\end{array}$ & Do. \\
\hline 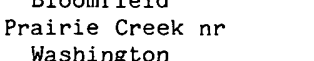 & 03360800 & 120 & $\begin{array}{l}1960,1962 \\
\text { to } 1965 .\end{array}$ & Do. \\
\hline $\begin{array}{l}\text { nashington } \\
\text { Indiana creak } \\
\text { Trinity }\end{array}$ & 03373320 & 172 & $\begin{array}{l}\text { to } 1961 \text { to } 1967967 \\
1967\end{array}$ & Do. \\
\hline 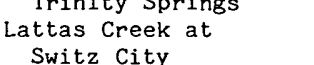 & 03360200 & 33 & $\begin{array}{l}1954,1960 \text { to } \\
1965\end{array}$ & Do. \\
\hline $\begin{array}{l}\text { Big Wanut Creek } \mathrm{nr} \\
\text { Barnard }\end{array}$ & 03357300 & 119 & $\begin{array}{l}1961 \text { to } 1965, \\
1967\end{array}$ & Do. \\
\hline $\begin{array}{l}\text { Radtriesnake Creek } \\
\text { nnt Spencer }\end{array}$ & 0337100 & 25 & $\begin{array}{l}1960 \text { to } 1965, \\
1967\end{array}$ & Do. \\
\hline $\begin{array}{l}\text { Black Creek } \\
\text { Sandborn }\end{array}$ & 03360700 & 109 & $\begin{array}{l}1960 \text { to } 1963, \\
1965,1967\end{array}$ & Do. \\
\hline 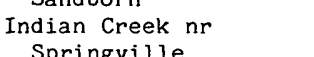 & 03373200 & 61 & 1961 to 1973 & Do. \\
\hline $\begin{array}{l}\text { Lick Creek nr } \\
\text { Lick }\end{array}$ & 03373600 & 19 & 1962 to 1967 & Do. \\
\hline Mud Creek $n$ & 03357700 & 35 & 1976 to 1978 & Do. \\
\hline $\begin{array}{l}\text { veles Creek } \mathrm{nr} \\
\text { veles }\end{array}$ & 03360860 & 29 & 1974 to 1978 & Do. \\
\hline $\begin{array}{l}\text { Wast ingeron } \\
\text { Lost River } n r\end{array}$ & 03373530 & 35 & 1976 to 1978 & Do. \\
\hline $\begin{array}{l}\text { Upper River Deshee } \\
\text { Uuver }\end{array}$ & 03374050 & 15 & 1976 to 1978 & Do. \\
\hline 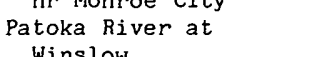 & 03376300 & 603 & 1963 to 1974 & Continuous \\
\hline $\begin{array}{l}\text { Winslow } \\
\text { chear ronch at Cory } \\
\text { veales Creek trib- }\end{array}$ & $\begin{array}{l}03360100 \\
03360850\end{array}$ & $\begin{array}{l}.27 \\
.27\end{array}$ & $\begin{array}{l}1973 \text { to present } \\
1973 \text { to present }\end{array}$ & $\begin{array}{l}\text { Crest stage } \\
\text { Do. }\end{array}$ \\
\hline $\begin{array}{l}\text { Shiloh drain } \mathrm{nr} \\
\text { Shiton }\end{array}$ & 03376230 & .57 & 1973 to present & Do. \\
\hline $\begin{array}{l}\text { Jasper } \\
\text { Patoka River trib- }\end{array}$ & 03376600 & .40 & 1973 to present & Do. \\
\hline $\begin{array}{l}\text { utary nh patoka } \\
\text { Doans creek trib- }\end{array}$ & 03360400 & .20 & 1973 to present & Do. \\
\hline $\begin{array}{l}\text { utary nr Doans } \\
\text { River Deshee trib- }\end{array}$ & 03346650 & .82 & 1973 to present & Do. \\
\hline $\begin{array}{l}\text { utary nr Frichton } \\
\text { Miller diton trib- }\end{array}$ & 03360750 & .50 & 1973 to present & Do. \\
\hline $\begin{array}{l}\text { utary nr Bicknel } \\
\text { Spring reek trib- } \\
\text { utary nor Spring }\end{array}$ & 03373240 & .54 & 1972 to present & Do. \\
\hline $\begin{array}{l}\text { vilite Creek trib- } \\
\text { Slate }\end{array}$ & 03373850 & .14 & 1973 to present & Do. \\
\hline $\begin{array}{l}\text { utary nr Hassvinie } \\
\text { French Lick Creek } \\
\text { tributary nr } \\
\text { French Lick }\end{array}$ & 03373680 & .29 & 1973 to present & Do. \\
\hline $\begin{array}{l}\text { Limestone creek } \\
\text { tributary nr } \\
\text { tribtan }\end{array}$ & 03356780 & .72 & 1972 to present & Do. \\
\hline $\begin{array}{l}\text { Gosport } \\
\text { Patoka River trib- }\end{array}$ & 03376340 & .84 & 1973 to present & Do. \\
\hline $\begin{array}{l}\text { utary nr Glezen } \\
\text { owl creek trib- }\end{array}$ & 03357430 & .58 & 1973 to present & Do. \\
\hline 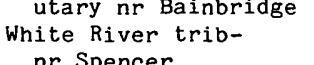 & 03357010 & .32 & 1973 to 1978 & Do. \\
\hline
\end{tabular}

EXPLANATION

Gaging Stations

$\Delta$ Continuouserecord

- Crest-stage

$\checkmark$ Low-flow

03357300 Station number
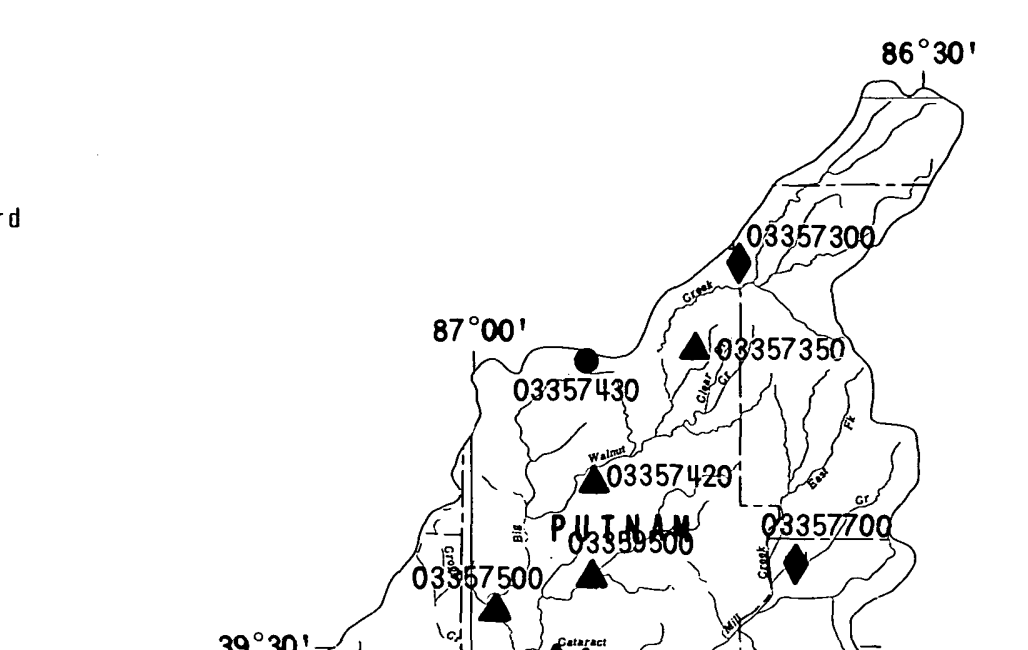

$39^{\circ} 30^{\prime}$

03360050 o

6. a a Y 03560000 है।

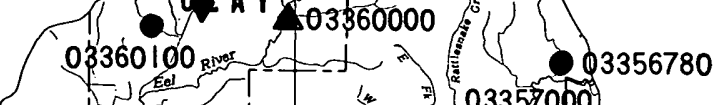

203357000

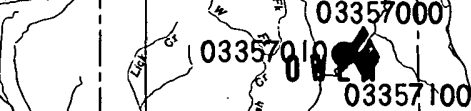

(1)

$G$ REENE

(

$39^{\circ} 00^{\prime}$
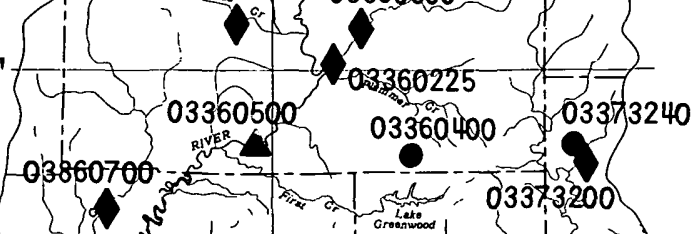

(1)

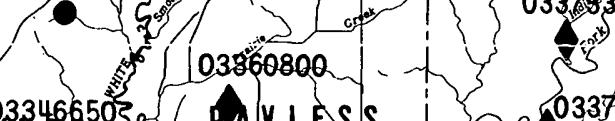

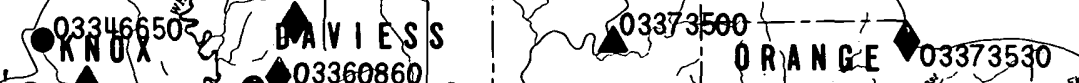

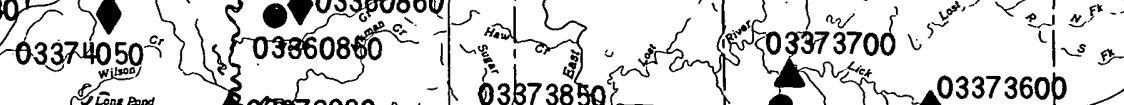

$38^{\circ} 30^{\prime}$. 03374100
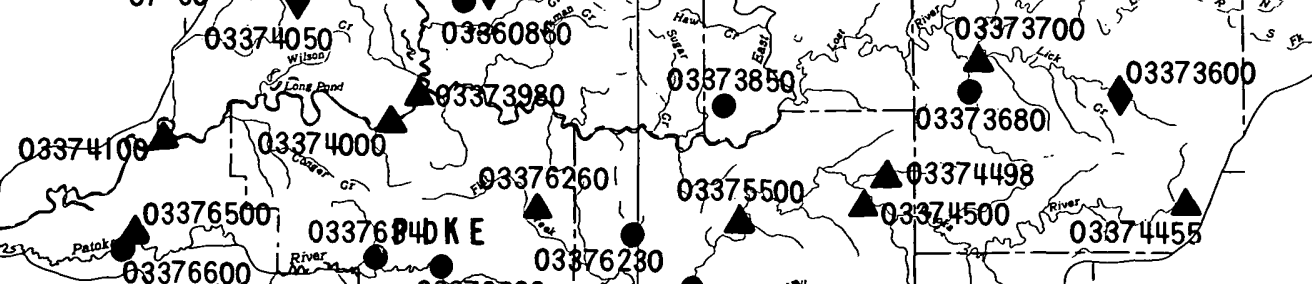

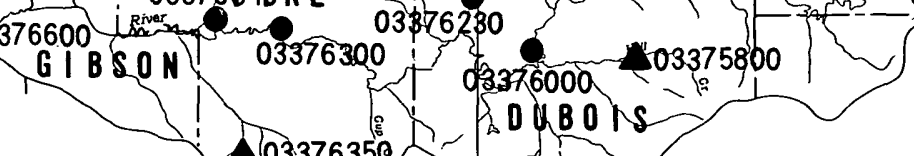

BASE FROM U.S. GEOLOGI CAL SURVEY

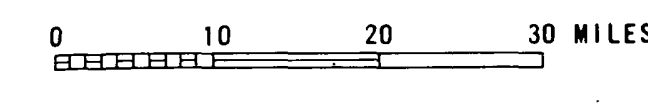

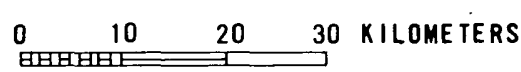

Figure 2.1. -- Gaging stations 


\title{
2.0 SURFACE WATER \\ 2.2 Low-Flow Frequency
}

\section{ESTIMATES OF 7-DAY, 10-YEAR LOW FLOW PRESENTED FOR 38 STATIONS}

\author{
The 7-day, 10-year low flow is the lowest average rate of flow for 7 \\ consecutive days to which streamflow can be expected to \\ decline in 1 year out of 10.
}

Two types of analyses were used to obtain estimates of the 7-day, 10-year low flow at 38 stations. Where a sufficient continuous record was available, a Geological Survey computer program (Hutchison, 1975) was used for a statistical analysis. The program fits the low-flow values to a log-Pearson TypeIII frequency distribution. For partial-record stations, the frequency was estimated by correlating the measured flows with concurrent flows at a long-term, continuous-record index site where the low-flow frequency curve has been defined. Streamflow at partial-record sites was measured during periods of base flow, when flow is primarily from ground-water storage.

The Crawford Upland comprises the largest physiographic unit in the study area. The highly dissected unit represents a diverse area in terms of surface-water flow. The steep slope of the unit results in rapid runoff and little sustained flow.
However, where erosion has been severe enough to penetrate into the karst limestone, numerous springs can occur (Schneider, 1966).

Most of the remainder of Area 32 is in the Wabash Lowlands. This lowland, underlain by siltstone and shale beds, is capped by a layer of glacial till in its north part (Schneider, 1966). The 7-day, 10-year low flow values for the lowland are minimal, owing to the absence of surficial aquifers. An exception is the outwash areas along major streams, which store water during high flow and rainstorms and release it to the streams during low-flow periods.

Locations of the stations where streamflow data have been used to calculate 7-day, 10-year low flow are shown on the adjoining map (fig. 2.2). Calculated values are listed in table 2.2 . 


\section{EPLANATIO}

Gaging Stations

Continuous-record

- Crest-stage

$\checkmark \quad$ Low-flow

03357300 Station numbe

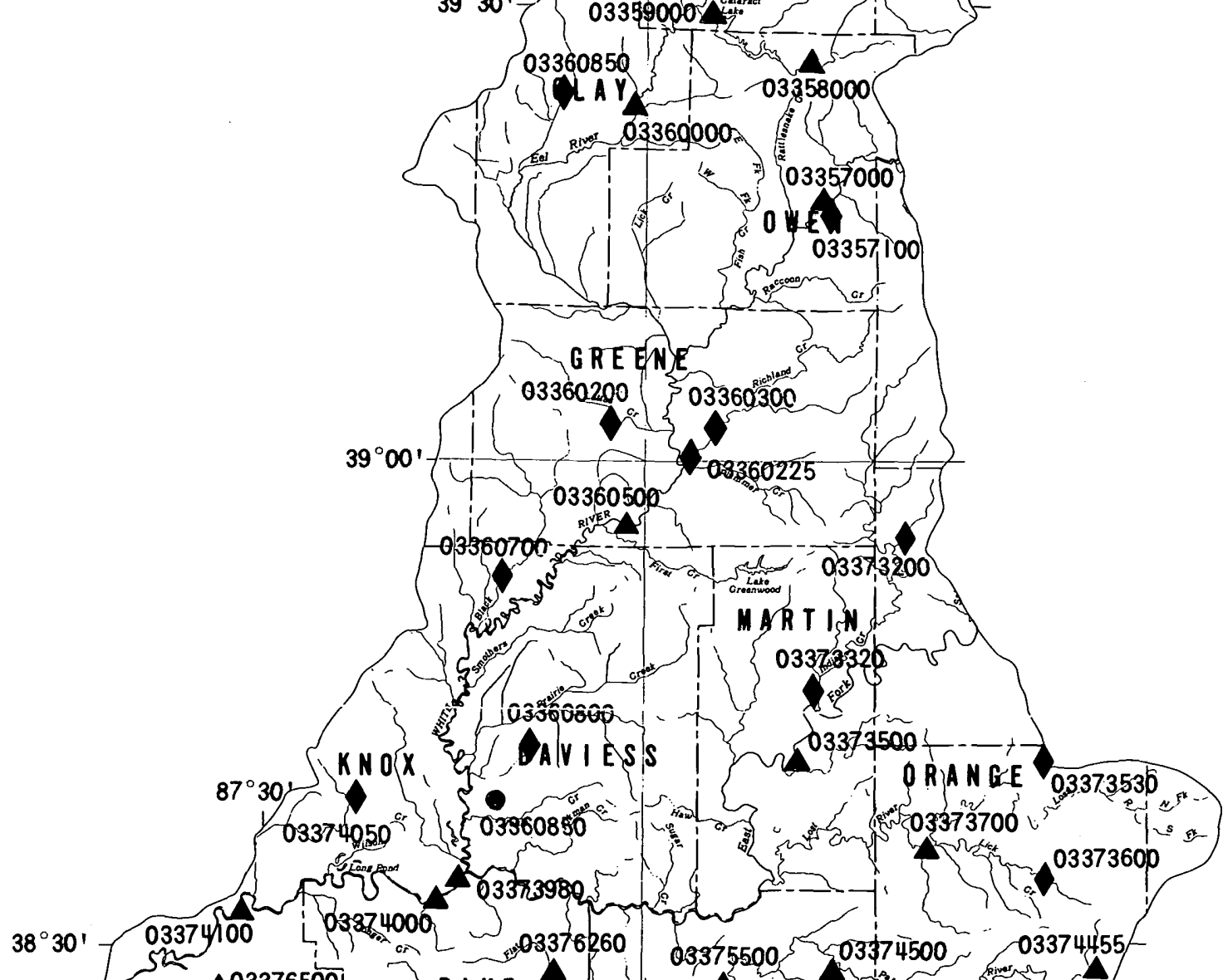

$39^{\circ} 00$

$39^{\circ} 30^{\prime}$

03360850

Y) 120358000

PUTMam

$38^{\circ} 30^{\prime} 03374100$ L

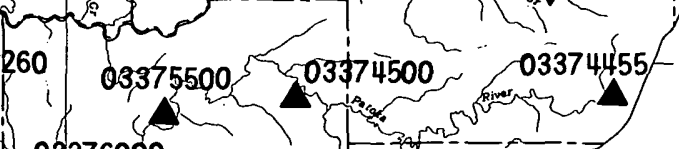

GI BSON

مि3376350

C. 03375800 .

Soybons

BASE FROM U.S. GEOLGICAL SUREY

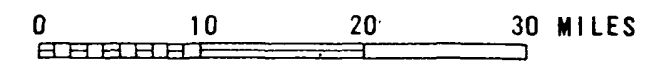

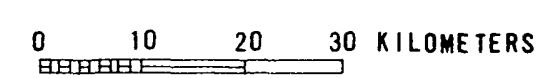

Table 2.2.--Estimates of 7-day, 10-year low flow

\begin{tabular}{|c|c|c|c|}
\hline Station name & $\begin{array}{l}\text { Station } \\
\text { number }\end{array}$ & $\begin{array}{c}\text { Drainage } \\
\text { area } \\
\left(\mathrm{mi}^{2}\right)\end{array}$ & $\begin{array}{l}Q 7,10 \\
\left(\mathrm{ft}^{3} / \mathrm{s}\right)\end{array}$ \\
\hline South Fork Patoka River $\mathrm{nr}$ Spurgeon & 03376350 & 42.8 & 2.2 \\
\hline Hall Creek nr St. Anthony & 03375800 & 21.8 & 0 \\
\hline Patoka River nr Princeton & 03376500 & 822 & 1.4 \\
\hline Flat Creek nr Otwell & 03376260 & 21.3 & 0 \\
\hline Patoka River at Jasper & 03375500 & 262 & 0 \\
\hline Patoka River nr Ellsworth & 03374500 & 171 & .2 \\
\hline Patoka River nr Hardinsburg & 03374455 & 12.8 & 0 \\
\hline White River at Hazleton & 03374100 & $11,30 r$ & (1) \\
\hline White River at Petersburg & 03374000 & 11,125 & 790 \\
\hline White River above Petersburg & 03373980 & 11,123 & (1) \\
\hline Lost River $\mathrm{nr}$ West Baden Springs & 03373700 & 287 & 10.4 \\
\hline East Fork White River at Shoals & 03373500 & 4,927 & 275 \\
\hline White River at Newberry & 03360500 & 4,688 & 319 \\
\hline Eel River at Bowling Green & 03360000 & 830 & $217.6 / 19.5$ \\
\hline Mill Creek nr Manhattan & 03359000 & 294 & ${ }^{2} 1.0 / 2.4$ \\
\hline Mill Creek nr Cataract & 03358000 & 245 & 1.4 \\
\hline Big Walnut Creek nr Reelsville & 03357500 & 326 & 5.7 \\
\hline Big Walnut Creek at Greencastle & 03357420 & 216 & (I) \\
\hline Plum Creek nr Bainbridge & 03357350 & 3.0 & 0 \\
\hline White River at Spencer & 03357000 & 2,988 & 226 \\
\hline Deer Creek nr Putnamville & 03359500 & 59 & .1 \\
\hline Patoka River nr Jasper & 03376000 & 342 & (1) \\
\hline Patoka River at Winslow & 03376300 & 603 & 1.1 \\
\hline Birch Creek nr Ashboro & 03360050 & 40 & 1.1 \\
\hline Richland Creek nr Bloomfield & 03360300 & 95 & .5 \\
\hline Plummer Creek nr Bloomfield & 03360225 & 67 & 0 \\
\hline Prairie Creek $\mathrm{nr}$ Washington & 03360800 & 120 & .1 \\
\hline Indiana Creek $\mathrm{nr}$ Trinity Springs & 03373320 & 172 & .1 \\
\hline Lattas Creek at Switz City & 03360200 & 33 & \\
\hline Big Walnut Creek nr Barnard & 03357300 & 119 & 1.6 \\
\hline Rattlesnake Creek nr Spencer & 03357100 & 25 & .2 \\
\hline Black Creek nr Sandborn & 03360700 & 109 & 2.5 \\
\hline Indian Creek nr Springville & 03373200 & 61 & 0 \\
\hline Lick Creek nr Paoli & 03373600 & 19 & .1 \\
\hline Mud Creek nr Little Point & 03357700 & 35 & (1) \\
\hline Veales Creek $\mathrm{nr}$ Washington & 03360850 & 29 & (1) \\
\hline Lost River nr Orleans & 03373530 & 35 & (1) \\
\hline Upper River Deshee nr Monroe City & 03374050 & 15 & (1) \\
\hline
\end{tabular}

Insufficient data.

${ }^{2}$ Unregulated flow/regulated flow.

Figure 2.2.- Data sites for 7-day, 10-year low-flow calculations. 


\title{
2.0 SURFACE WATER \\ 2.3 Flood Frequency
}

\section{FLOOD FREQUENCIES ESTIMATED FOR SELECTED GAGING STATIONS}

\author{
The 10-, 25-, 50-, and 100-year floods are floods of magnitudes that \\ are expected to be equaled or exceeded once during any 10-, 25-, \\ 50-, or 100-year recurrence interval. These floods have a \\ 10, 4, 2 or 1 percent chance, respectively, of being \\ equaled or exceeded during any year.
}

Estimates of discharge for the 10-, 25-, 50-, and 100-year flood frequencies are presented for selected gaging stations. The recurrence interval represents the long-term average period between floods of a specific magnitude; however, floods of a higher magnitude can occur at a shorter interval or even within a given year. Estimates of flood peaks are listed in table 2.3. The relation between discharge and drainage area for three major rivers within Area 32 is shown in the adjoining curves (fig. 2.3a), and locations of the gaging stations used to compute flood peaks are shown in figure $2.3 \mathrm{~b}$.

Discharge records of less than 5 years are insufficient to compute flood peaks. Where discharge records for 5 to 10 years were available, the 10-year flood was computed. Where records for more than 10 years were available, flood frequencies of 10-, 25-, $50-$, and 100-years were computed.
Davis (1974) and Gold (1980) prepared manuals that provide methods for estimating the magnitude and the frequency of floods on unregulated and unurbanized Indiana streams. Additional methods are provided by the U.S. Soil Conservation Service (1975) for areas less than 2,000 acres. Davis (1974) and Gold (1980) found that precipitation index (precipitation minus snowfall and evapotranspiration) is the controlling factor on flood magnitude for most streams in the study area. Davis (1974) concluded that, for the Wabash and White Rivers, drainage area, channel slope, and stream length are the dominant factors and that precipitation index is insignificant. Precipitation index ranges from 10 in the north end of the study to 16 in the south (Davis, 1974 ) and from 5 to 18 in the rest of Indiana. Thus, flood magnitude for streams in the study area is moderately high compared to that for the rest of the streams in the State. 

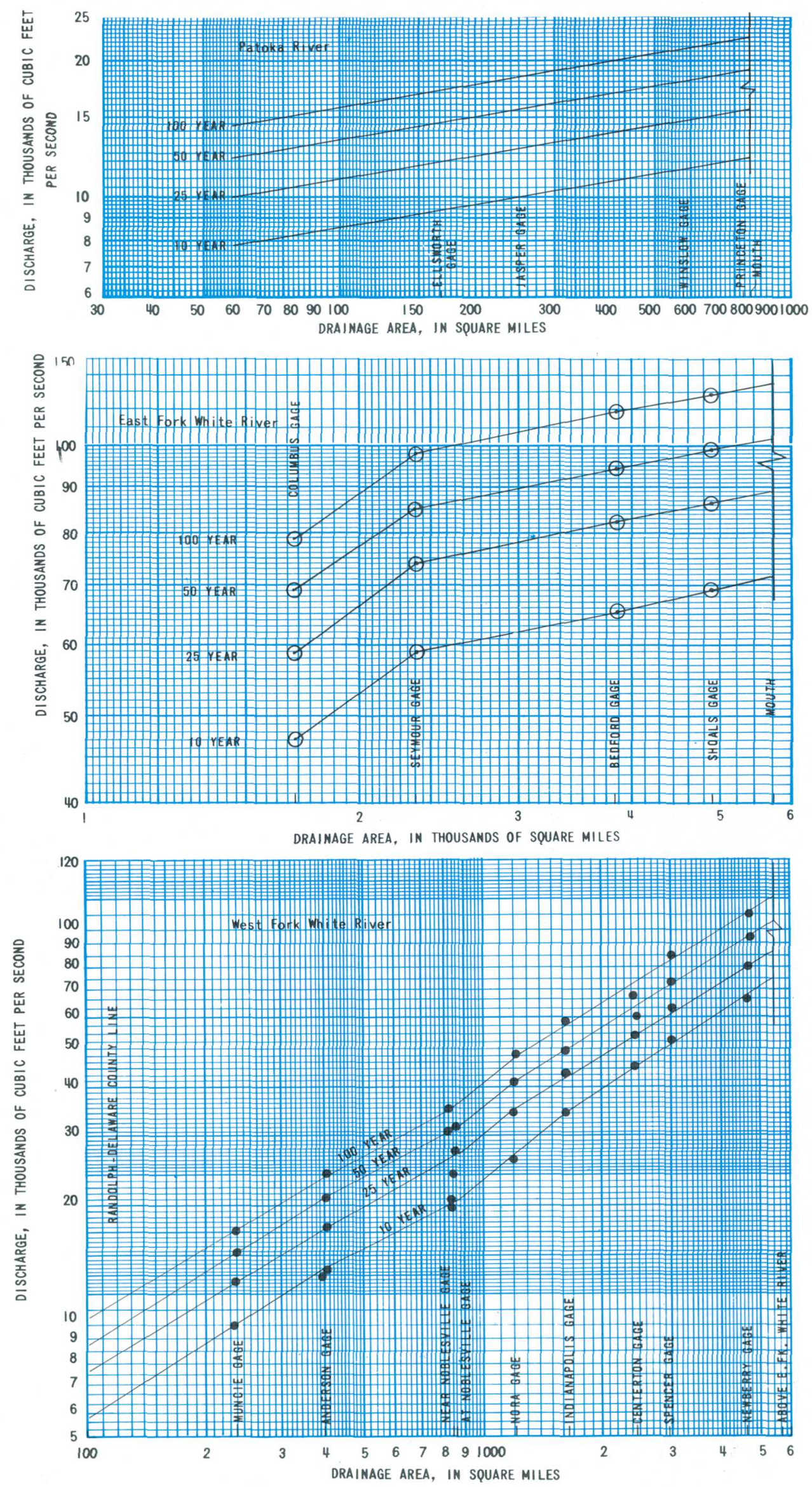

Figure 2.3a... Relation of drainage area to discharge

\begin{tabular}{|c|c|c|c|c|c|c|c|}
\hline $\begin{array}{l}\text { Station } \\
\text { name }\end{array}$ & 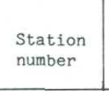 & 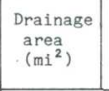 & $\begin{array}{l}\text { 年ars } \\
\text { record } \\
\text { record }\end{array}$ & \begin{tabular}{|l|l|}
100 \\
years
\end{tabular} & \begin{tabular}{|l}
25 \\
years
\end{tabular} & $\begin{array}{l}50 \\
\text { years }\end{array}$ & \begin{tabular}{|l|l}
100 \\
years
\end{tabular} \\
\hline 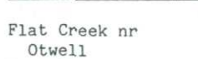 & 03376250 & 21.3 & 15 & 1,390 & 1,480 & 1,540 & 1,59 \\
\hline 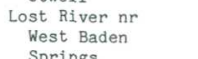 & 03373700 & & 15 & 6,980 & 8,160 & 8,980 & 9,760 \\
\hline 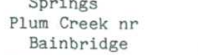 & 03357350 & 3.0 & 10 & ${ }^{634}$ & ${ }^{757}$ & 844 & 92 \\
\hline & 03359500 & 59 & ${ }_{11}^{11}$ & 9,560 & 11,300 & 12,500 & 13,600 \\
\hline 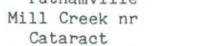 & 03358000 & 245 & 30 & 9,680 & 11,700 & 13,100 & 14,500 \\
\hline 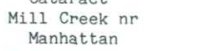 & 03359000 & 294 & 15 & 6,550 & 7,480 & 8,040 & 8,550 \\
\hline 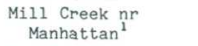 & 03359000 & 294 & 26 & 3,320 & 3,600 & 3,780 & 3,040 \\
\hline 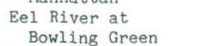 & 03360000 & 830 & 22 & 24,900 & 31,900 & 37,800 & 44,400 \\
\hline 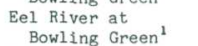 & 03360000 & 830 & 26 & 23,600 & 29,800 & 34,400 & 38,800 \\
\hline 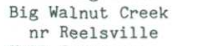 & 03355500 & 326 & 30 & 18,200 & 22,600 & 25,700 & 28,600 \\
\hline 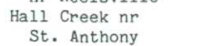 & 03375800 & 21.8 & 9 & 3,890 & (2) & (2) & (2) \\
\hline 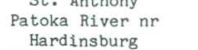 & 03374455 & 12.8 & 11 & 2,110 & 2,800 & 3,500 & 4,44tc \\
\hline 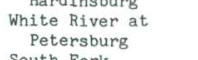 & 03374000 & 11,125 & 52 & 125,000 & 148,000 & 163,000 & 176,000 \\
\hline 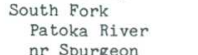 & 03376350 & 42.8 & 15 & 3,480 & 3,940 & 4,260 & 4,55 \\
\hline 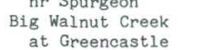 & 03357420 & 216 & 5 & 9,520 & (2) & (2) & (2) \\
\hline 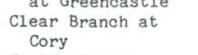 & 03360100 & .27 & 6 & 102 & (2) & (2) & (2) \\
\hline 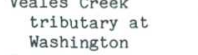 & 03360050 & .27 & 6 & 215 & (2) & (2) & (2) \\
\hline 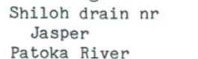 & 03372320 & .57 & 6 & 288 & (2) & (2) & (2) \\
\hline 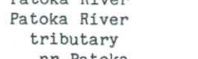 & 03376600 & .40 & 6 & 186 & (2) & (2) & (2) \\
\hline 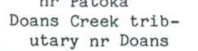 & 03360400 & .20 & 6 & 120 & (2) & (2) & (2) \\
\hline 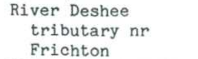 & 03346550 & .82 & 6 & 182 & (2) & (2) & (2) \\
\hline $\begin{array}{l}\text { Miller dittoh trib- } \\
\text { utary nh } \\
\text { Bicknol }\end{array}$ & 03360750 & .50 & 6 & 125 & (2) & (2) & (2) \\
\hline 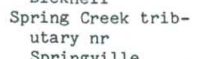 & 03373240 & .54 & 7 & 260 & (2) & (2) & (2) \\
\hline $\begin{array}{l}\text { "late Creek trib- } \\
\text { utary no trib- }\end{array}$ & 03373850 & .14 & 6 & 129 & (2) & (2) & (2) \\
\hline 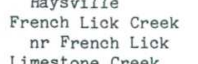 & 03736880 & .29 & 6 & 205 & (2) & (2) & (2) \\
\hline 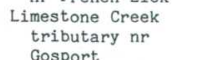 & 03356780 & .72 & 7 & 221 & (2) & (2) & (2) \\
\hline $\begin{array}{l}\text { Patokek aiver } \\
\text { tributatary } \\
\text { tror }\end{array}$ & 03376340 & .84 & 6 & 259 & (2) & (2) & (2) \\
\hline 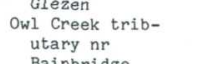 & 03357430 & .58 & 6 & 366 & (2) & (2) & (2) \\
\hline 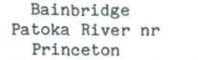 & 03375500 & 822 & 45 & See a & curve on & ajsaent & ure \\
\hline 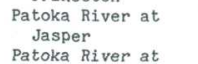 & 03375500 & 262 & 32 & $D$ & & & \\
\hline 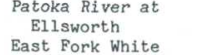 & 03374500 & 171 & 18 & & & & \\
\hline 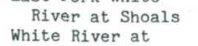 & 03373500 & 4,927 & 67 & & & & \\
\hline 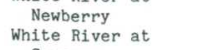 & 03360500 & 4,688 & 51 & $D$ & Do. & & \\
\hline 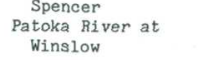 & $\begin{array}{l}03357000 \\
03376300\end{array}$ & $\begin{array}{r}2,988 \\
603\end{array}$ & $\begin{array}{l}46 \\
11\end{array}$ & & po. & & \\
\hline
\end{tabular}

$87^{\circ} 00^{\prime}$

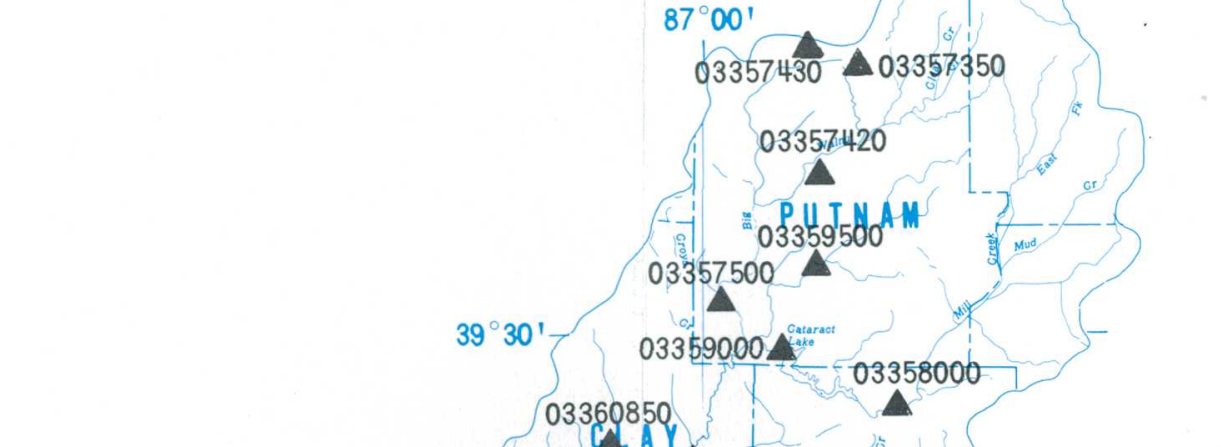

03360850 -

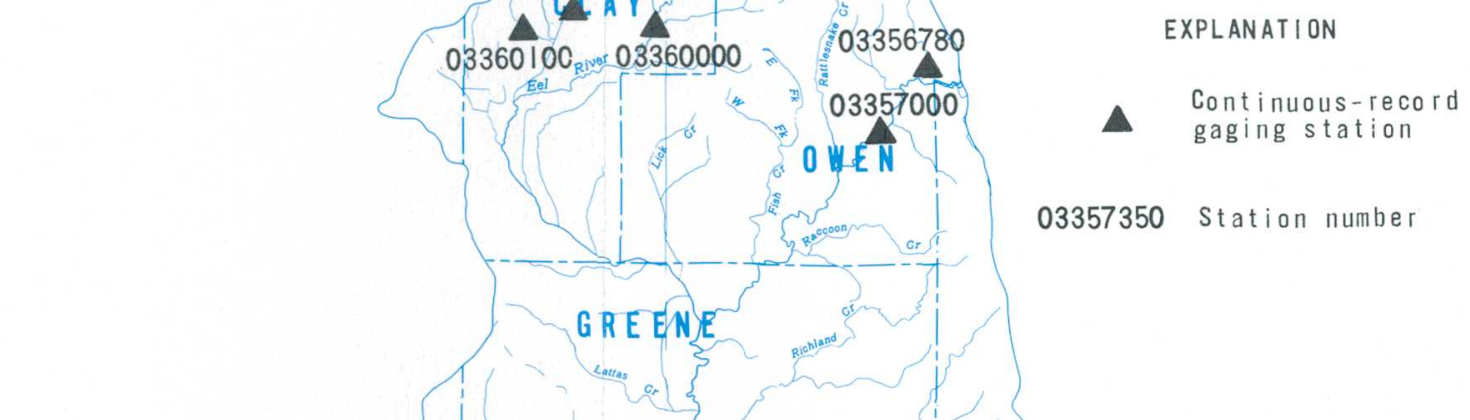

BASE FROM U.S. GEOLOGI CAL SURVEY

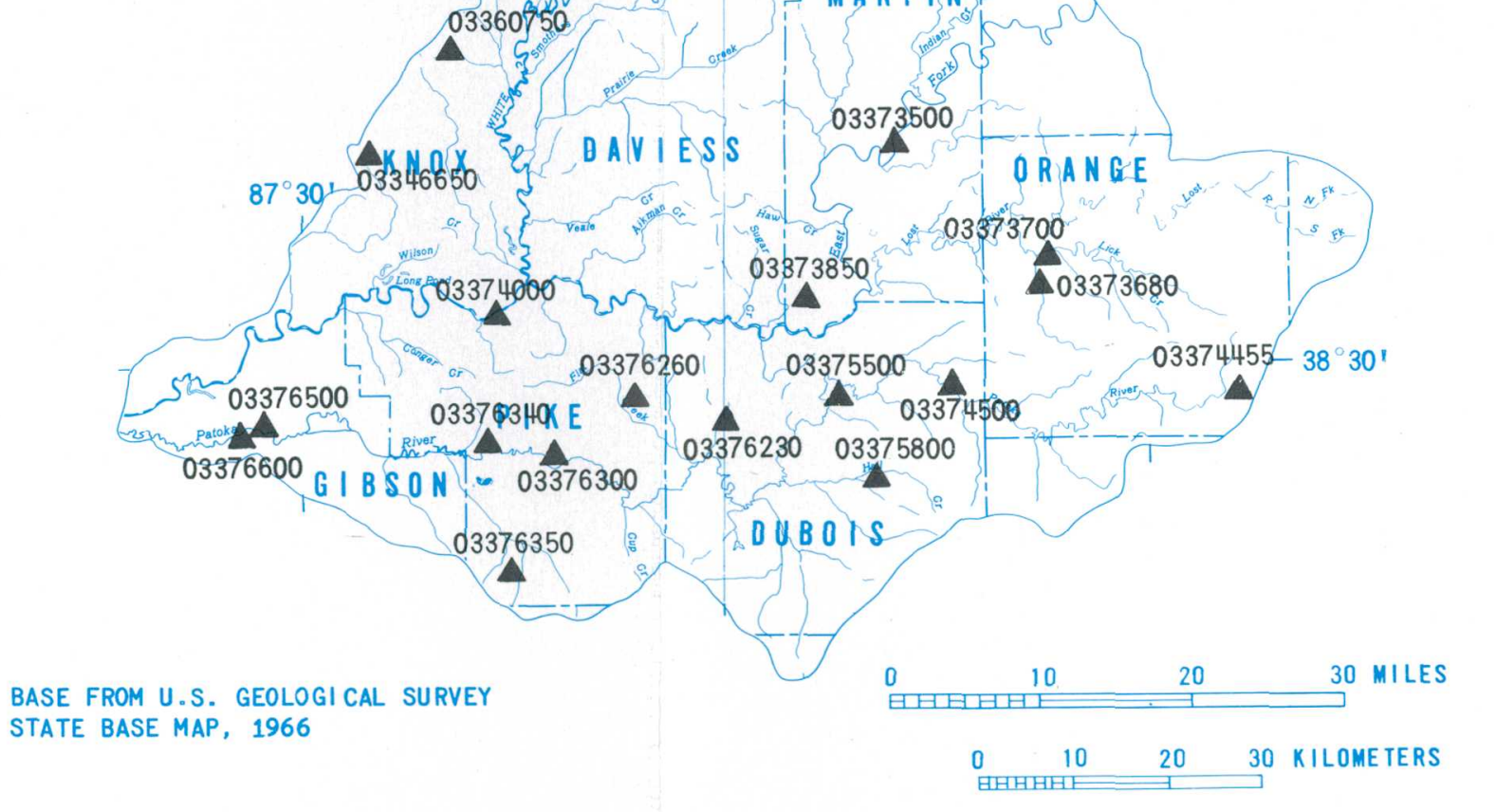

Figure 2.3b. - Data sites for flood-frequency calculations. 


\title{
2.0 SURFACE WATER
}

2.4 Duration Curves

\section{DURATION CURVES FOR SELECTED GAGING STATIONS}

\author{
Flow-duration curves show the percent of time that specified discharges \\ were equaled or exceeded during a given period of record. \\ Curves developed for the White River at Newberry, Flat Creek \\ near Cataract, and Eel River at Bowling Green indicate a \\ wide variation of sustained flow in the area.
}

Duration curves for four gaging stations are presented in figure 2.4a. The 95-, 90-, 75-, 70-, 50-, 25-, and 10-percent flow durations for 15 additional stations are listed in table 2.4. Locations of the stations are shown on the adjoining map (fig. 2.4b). Two sets of data were developed for the Eel River at Bowling Green and Mill Creek near Manhattan, one for the period of record through 1952, before the constructon of Cagles Mill Lake, and the second, for 1955 through 1979, after the reservoir was put into operation.

A Geological Survey computer program (Hutchison, 1975) was used to compute flow duration by a magnitude-frequency analysis of daily discharge values. The computed values, listed in the following table, were used to construct the duration curves in the adjoining figure $2.4 \mathrm{a}$.

A wide variation in streamflow is indicated by the duration curves for streams in the study area. Broad rivers with low slopes have a sustained flow, but streams with steep slopes, and low recharge due to the lack of surficial aquifers, sustain little flow. (See the steep slope at the lower end of the duration curve in figure 2.4a.) 
ble 2.4--Flow duration at selected gaging stations

\begin{tabular}{|c|c|c|c|c|c|c|c|c|c|}
\hline Station name & $\begin{array}{l}\text { Station } \\
\text { number }\end{array}$ & $\begin{array}{l}\text { Period of } \\
\text { record } \\
\text { used }\end{array}$ & $\frac{\text { Percent }}{95}$ & $\begin{array}{l}\text { tof time } \\
90\end{array}$ & $\frac{\text { issharge }}{75}$ & $\int_{0}^{\text {in cub }}$ & $\frac{\text { feet per }}{50}$ & $\begin{array}{l}\text { second ex } \\
25\end{array}$ & $\frac{\text { exceeded }}{10}$ \\
\hline $\begin{array}{l}\text { South Fork Patoka } \\
\text { River near } \\
\text { Spurgeon }\end{array}$ & 03376350 & 1966 to 1979 & 4.8 & 6.1 & 10 & 12 & 23 & 52 & 120 \\
\hline $\begin{array}{l}\text { Hall Creek near } \\
\text { St. Anthony }\end{array}$ & 03375800 & 1972 to 1979 & .1 & .3 & 1.7 & 2.5 & 8.0 & 25 & 72 \\
\hline $\begin{array}{l}\text { Patoka River near } \\
\text { Princeton }\end{array}$ & 03376500 & 1936 to 1977 & 10 & 17 & 54 & 72 & 270 & $1,500^{\circ}$ & 2,800 \\
\hline $\begin{array}{l}\text { Flat Creek near } \\
\text { Otwell }\end{array}$ & 03376260 & 1966 to 1979 & & & See curve & $e$ in figur & are $2.4 a$. & & \\
\hline $\begin{array}{l}\text { Patoka River at } \\
\text { Jasper }\end{array}$ & 03375500 & 1949 to 1977 & 1.0 & 3.1 & 14 & 21 & 74 & 360 & 1,200 \\
\hline $\begin{array}{l}\text { Patoka River near } \\
\text { El1sworth }\end{array}$ & 03374500 & 1963 to 1977 & .9 & 2.0 & 9.7 & 14 & 51 & 200 & 660 \\
\hline $\begin{array}{l}\text { Patoka River near } \\
\text { Hardinsburg }\end{array}$ & 03374455 & 1970 to 1978 & $\cdot 3$ & .5 & 1.4 & 1.9 & 6.2 & 22 & 56 \\
\hline $\begin{array}{l}\text { White River at } \\
\text { Petersburg }\end{array}$ & 03374000 & 1929 to 1979 & 1,100 & 1,400 & 2,500 & 2,900 & 5,700 & 14,000 & 30,000 \\
\hline $\begin{array}{l}\text { Lost River near } \\
\text { West Baden } \\
\text { Springs }\end{array}$ & 03373700 & 1966 to 1979 & 19 & 24 & 49 & 62 & 160 & 430 & 960 \\
\hline $\begin{array}{l}\text { East Fork White } \\
\text { River at Shoals }\end{array}$ & 03373500 & 1905 to $1979^{1}$ & 380 & 490 & 890 & 1,100 & 2,400 & 6,500 & 14,000 \\
\hline $\begin{array}{l}\text { White River at } \\
\text { Newberry }\end{array}$ & 03360500 & 1930 to 1979 & & & See curve & $e$ in figur & are $2.4 a$. & & \\
\hline $\begin{array}{l}\text { Eel River at } \\
\text { Bowling Green }\end{array}$ & 03360000 & $\begin{array}{l}1932 \text { to } 1952^{1} \\
1955 \text { to } 1979^{2}\end{array}$ & & & $\begin{array}{l}\text { Do. } \\
\text { Do. }\end{array}$ & & & & \\
\hline $\begin{array}{l}\text { Mill Creek near } \\
\text { iranniaitianit }\end{array}$ & 03359000 & $\begin{array}{l}1941 \text { to } 1952 \\
1355 \text { to } 1978^{2}\end{array}$ & $\begin{array}{l}5.6 \\
2.7\end{array}$ & $\begin{array}{l}8.8 \\
4.2\end{array}$ & $\begin{array}{l}23 \\
20\end{array}$ & $\begin{array}{l}30 \\
30\end{array}$ & $\begin{array}{l}79 \\
89\end{array}$ & $\begin{array}{l}250 \\
210\end{array}$ & $\begin{array}{l}760 \\
980\end{array}$ \\
\hline $\begin{array}{l}\text { Mill Creek near } \\
\text { Cataract }\end{array}$ & 03358000 & 1951 to 1979 & & & See curve & $e$ in figur & ure $2.4 \mathrm{a}$. & & \\
\hline $\begin{array}{l}\text { Big Walnut Creek } \\
\text { near Reelsville }\end{array}$ & 03357500 & 1951 to 1979 & 14 & 21 & 50 & 62 & 140 & 340 & 760 \\
\hline $\begin{array}{l}\text { Plum Creek near } \\
\text { Bainbridge }\end{array}$ & 03357350 & 1971 to 1979 & .01 & .02 & .1 & .2 & 1 & 3.4 & 8.1 \\
\hline $\begin{array}{l}\text { Big Walnut Creek } \\
\text { near Reelsville }\end{array}$ & 03357500 & 1951 to 1979 & 14 & 21 & 50 & 62 & 140 & 340 & 760 \\
\hline $\begin{array}{l}\text { Plum Creek near } \\
\text { Bainbridge }\end{array}$ & 03357350 & 1971 to 1979 & .01 & .02 & .1 & .2 & 1 & 3.4 & 8.1 \\
\hline $\begin{array}{l}\text { White River at } \\
\text { Spencer }\end{array}$ & 03357000 & 1927 to 1971 & 330 & 400 & 630 & 730 & 1,400 & 3,200 & 6,900 \\
\hline $\begin{array}{l}\text { Deer Creek near } \\
\text { Putnamville }\end{array}$ & 03359500 & 1956 to 1972 & .6 & 1.2 & 4.4 & 6.1 & 18 & 48 & 110 \\
\hline $\begin{array}{l}\text { Patoka River at } \\
\text { Winslow }\end{array}$ & 03376300 & 1965 to 1974 & 4.1 & 8.3 & 33 & 47 & 200 & 1,000 & 1,900 \\
\hline
\end{tabular}

${ }^{1}$ No records for periods from 1906 to 1908 and 1916 to 1923.
${ }^{2}$ Record reflects regulated condition.

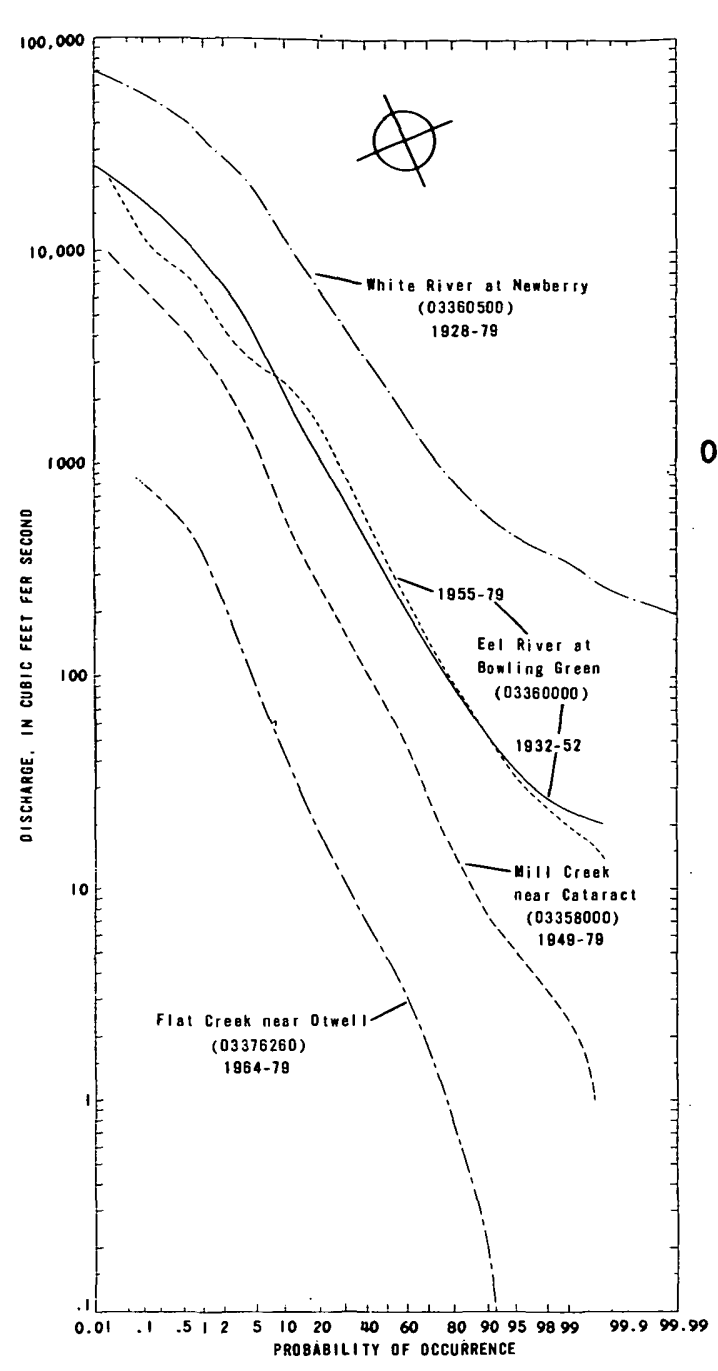
Figure 2.4a. - Duration curves
for selected sites.
Explanation

87 001
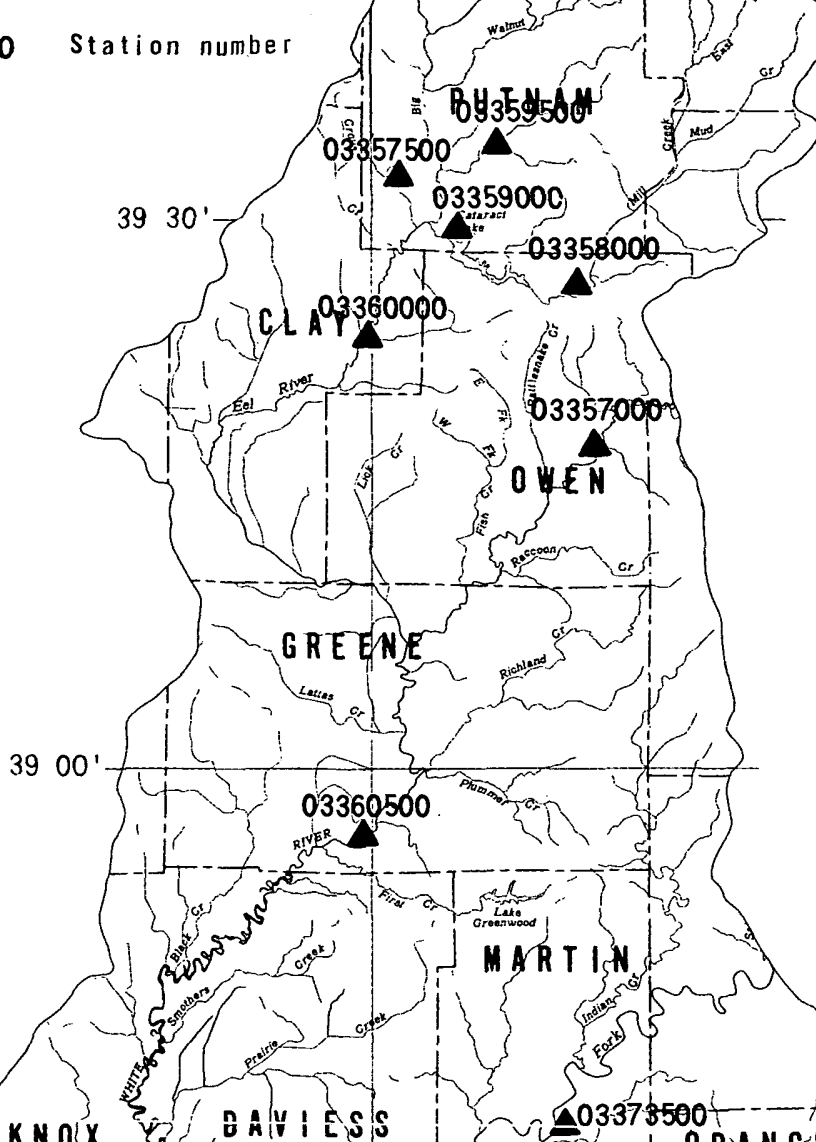

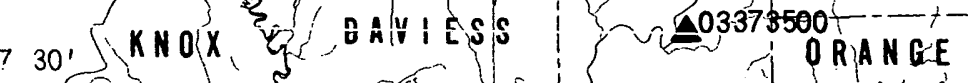
근

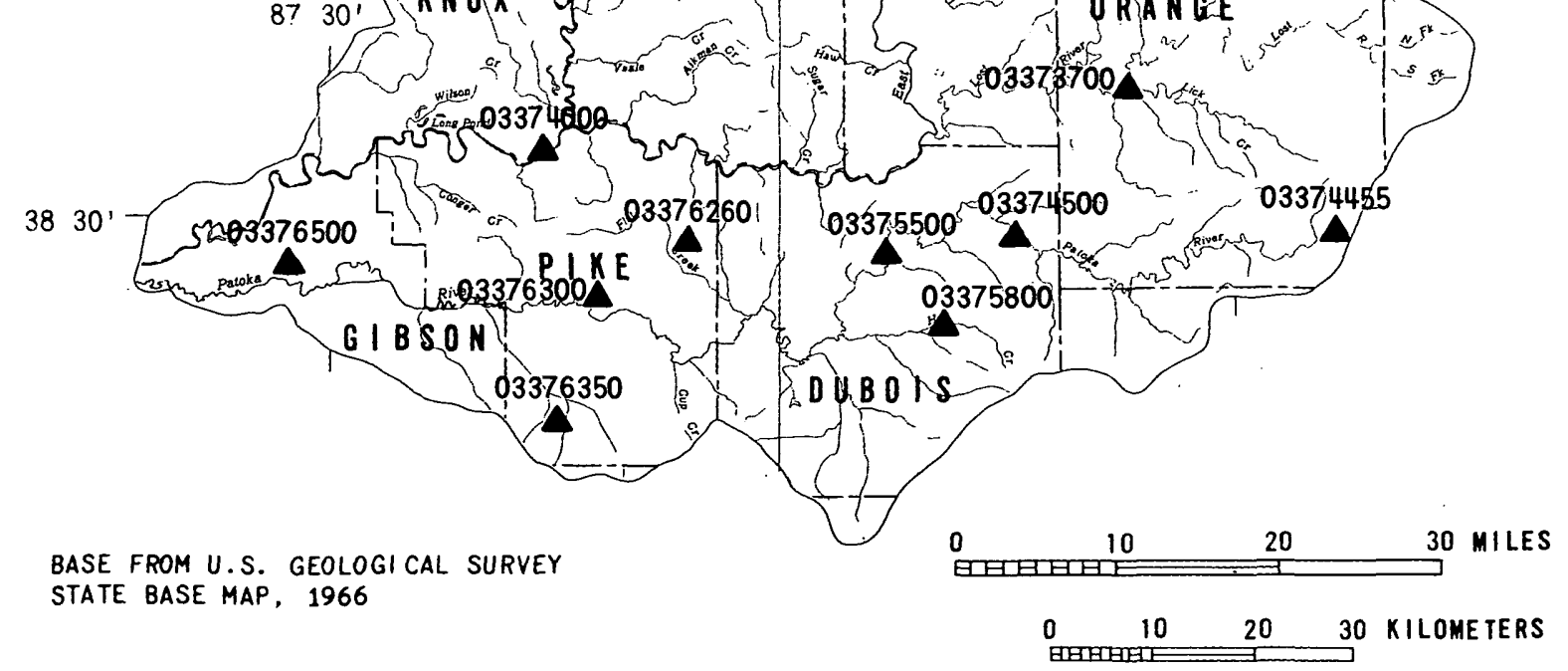

Figure 2.4b. -- Data sites for computation of duration curves 


\title{
2.0 SURFACE WATER \\ 2.5 Average Flow
}

\section{AVERAGE FLOW COMPUTED FOR SELECTED GAGING STATIONS}

\author{
Records of discharge for streams in Area 32 indicate that \\ average annual flow is proportional to drainage area.
}

Monthly mean discharges at 19 gaging stations are presented in the accompanying table 2.5. A Geological Survey computer program (Hutchison, 1975) was used to calculate monthly and annual average flows from daily discharges. Locations of the stations are shown in figure 2.5a. Two periods of record were used for the Eel River at Bowling Green and Mill Creek near Manhattan--one for the period of record through 1952, before the construction of
Cagles Mill Lake, and the second, for 1955 through 1979 , after the reservoir was put into operation.

The curve relating drainage area to mean annual discharge in figure $2.5 \mathrm{~b}$ indicates that average annual flow is predictable. The small variation around the curve indicates that the dominant factor affecting average annual flow is size of drainage area. 
Table 2.5.--Monthly mean discharge at selected gaging stations

\begin{tabular}{|c|c|c|c|c|c|c|c|c|c|c|c|c|c|}
\hline Station name & $\begin{array}{l}\text { Station } \\
\text { number }\end{array}$ & ctober & November & December & January & $\begin{array}{l}\text { nenhy mean } \\
\text { |February }\end{array}$ & $\begin{array}{l}\text { itischarge } \\
\text { | March }\end{array}$ & $\begin{array}{l}\text { Deriod } \\
\text { Apri1 }\end{array}$ & $\begin{array}{l}\text { record } \\
\text { May }\end{array}$ & $\frac{\left.s^{3 / s}\right)}{[1 \text { June }}$ & July & \begin{tabular}{|l|l} 
August \\
\end{tabular} & September \\
\hline $\begin{array}{l}\text { thth Fork patoka } \\
\text { River near } \\
\text { sourgeon }\end{array}$ & 76350 & 14.6 & 28.9 & 55.6 & 58.8 & 80.3 & 97.3 & 92.6 & 62.2 & 45.7 & 38.7 & 25.6 & 160 \\
\hline $\begin{array}{l}\text { Sourgeon } \\
\text { toka } \\
\text { naver }\end{array}$ & 03376500 & 193 & 355 & 765 & 1,524 & 1,762 & 2,346 & 1,984 & 1,386 & 694 & 393 & 243 & 170 \\
\hline 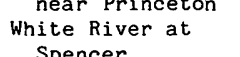 & 03357000 & 931 & 1,589 & 2,490 & 4,497 & 4,484 & 5,242 & 5,584 & 4,064 & 2,808 & 1,865 & 1,048 & 1,039 \\
\hline 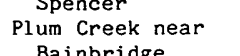 & 03357350 & 1.41 & 3.56 & 5.35 & 4.29 & 6.31 & 8.43 & 5.23 & 3.18 & 2.96 & 3.52 & 1.61 & 56 \\
\hline 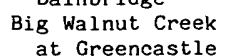 & 03357420 & 88.4 & 79.5 & 287 & 235 & 383 & 656 & 294 & 208 & 119 & 261 & 179 & 48.6 \\
\hline 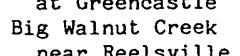 & 03357500 & 82.6 & 204 & 382 & 507 & 525 & 675 & 597 & ${ }_{418}$ & 338 & 227 & 126 & 91.6 \\
\hline er cree & 03359500 & 11.1 & 31.4 & 59.6 & 75.4 & 93.3 & 120 & 123 & 79.5 & 60.8 & 29.6 & 12.5 & 29.8 \\
\hline 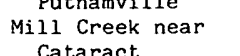 & 03358000 & 47.1 & 188 & 304 & 383 & 422 & 534 & 398 & 281 & 249 & 196 & 87.6 & 61.6 \\
\hline $\begin{array}{l}\text { } \\
\text { } 1111 \text { Creek near near } \\
\text { Manhatan }\end{array}$ & 03359000 & 47.8 & 200 & 254 & 585 & 486 & 518 & 547 & 401 & 333 & 105 & 66.7 & 86.8 \\
\hline 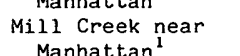 & 03359000 & 82.3 & 177 & 235 & 321 & 493 & 482 & 581 & 389 & 343 & 238 & 86.5 & 77.3 \\
\hline $\begin{array}{l}\text { Melanhat } \\
\text { Eee Riveg }\end{array}$ & 03360000 & 228 & 503 & 758 & 1,697 & 1,305 & 1,559 & 1,587 & 1,255 & 824 & 382 & 214 & 264 \\
\hline Eel $\mathrm{Ri}$ & 03360000 & 231 & 517 & 905 & 1,011 & 1,310 & 1,598 & 1,571 & 1,148 & 889 & 639 & 362 & 284 \\
\hline $\begin{array}{l}\text { White } \\
\text { White }\end{array}$ & 03360500 & 1,274 & 2,446 & 4,228 & 7,028 & 6,917 & 8,726 & 8,770 & 6,467 & 4,335 & 3,095 & 1,846 & 1,332 \\
\hline $\begin{array}{l}\text { East Fo } \\
\text { pa }\end{array}$ & 03373500 & 1,546 & 2,530 & 5,118 & 9,096 & 8,563 & 11,590 & 9,897 & 6,829 & 4,102 & 2,884 & 1,869 & 1,350 \\
\hline $\begin{array}{l}\text { Lost Rive } \\
\text { West be } \\
\text { Springs }\end{array}$ & 03373700 & 70.2 & 221 & 478 & 456 & 555 & 751 & 738 & 428 & 243 & 207 & 190 & 96.7 \\
\hline $\begin{array}{l}\text { White Riv } \\
\text { peterst } \\
\text { Pets }\end{array}$ & 03374000 & 2,891 & 5,534 & 10,140 & 17,980 & 18,040 & 23,330 & 21,560 & 15,930 & 10,300 & 7,187 & 4,579 & 3,089 \\
\hline near & 03374455 & 2.72 & 16.6 & 35.8 & 37.3 & 39.3 & 57.7 & 56.8 & 28.7 & 17.6 & 15.6 & 7.26 & 5 \\
\hline near & 03374500 & 22.9 & 104 & 237 & 323 & 384 & 618 & 455 & 247 & 125 & 54.6 & 45.3 & 29.6 \\
\hline & 03375500 & 44.2 & 188 & 389 & 635 & 688 & 897 & 653 & 434 & 196 & 99.5 & 62.1 & 39.2 \\
\hline & & 8.62 & 31.4 & 46.1 & 40 & 63. & 73. & & 20.4 & & 33.4 & 20.8 & .9 \\
\hline $\begin{array}{l}\text { Flat Creek near } \\
\text { otwell }\end{array}$ & 03376260 & 4.16 & 13.1 & 31.4 & 33.2 & 38.5 & 50.2 & 40.5 & 24.7 & 12.3 & 15.7 & 8.52 & \\
\hline
\end{tabular}

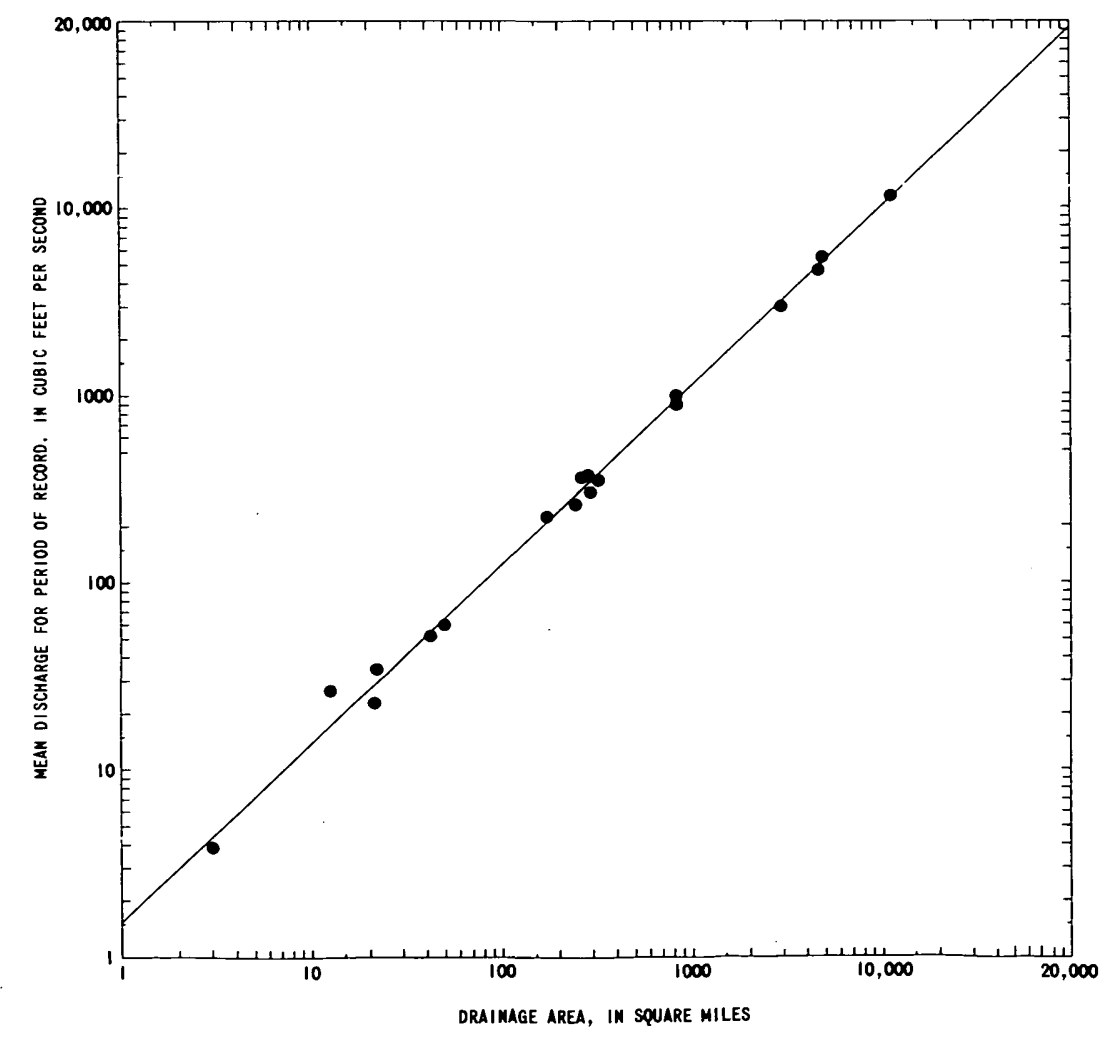

Figure 2.5b. .e Relation of drainage area to mean discharge

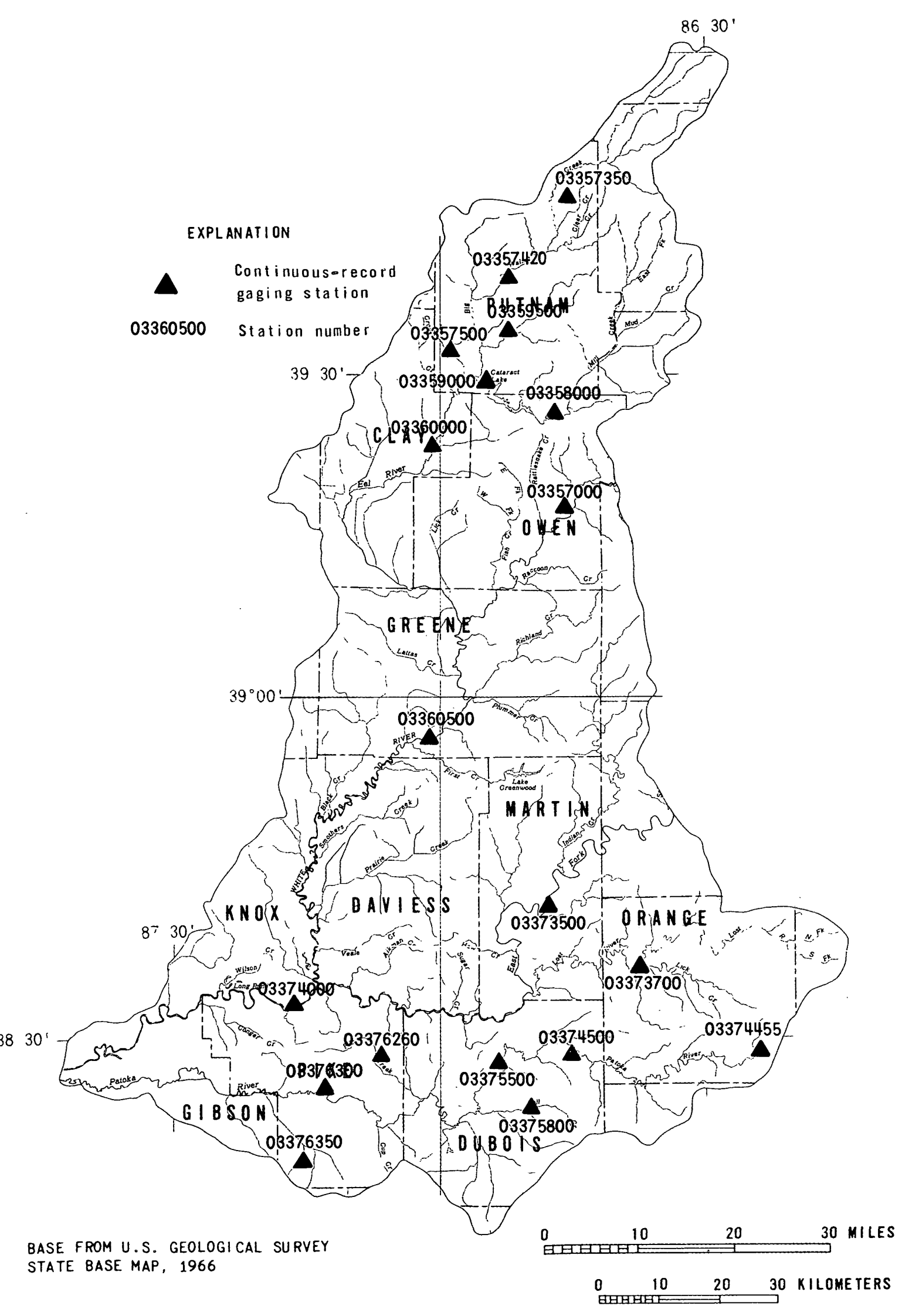

Figure 2.5a. -- Data sites for average-flow calculations. 


\title{
3.0 GROUND-WATER SYSTEM \\ 3.1 Aquifers
}

\section{GLACIAL DEPOSITS AND BEDROCK ARE SOURCES OF GROUND WATER}

\author{
Glacial sand and gravel deposits along streams and in buried valleys \\ and lenses of sand and gravel in till or lake deposits may yield \\ large supplies of water. Sandstone and coal of Pennsylvanian \\ age and limestone and sandstone of Mississippian age are sources \\ of small supplies of ground water.
}

Ground water is available from glacial sand and gravel deposits and from bedrock of Pennsylvanian and Mississippian ages. Glacial deposits yield the most water, but bedrock aquifers must be used in some areas.

Glacial sand and gravel deposits are classified in two groups: (1) valley train or outwash and (2) lenses in till or lake sediments. Valley train and outwash, which were deposited by glacial melt water, are found along modern streams or over buried bedrock valleys. Older outwash deposits can also be found in these buried valleys under till or lake deposits. These types of aquifers range in thickness from 10 to 80 feet and can yield large quantities of water. Isolated lenses of sand and gravel in till and lake sediments are usually found by trial and error drilling. Wells in the thicker and more widely distributed lenses can yield as much as a few hundred gallons per minute. Wells in the thinner and less widely distributed sand and gravel lenses yield only a few gallons per minute. Sand and gravel lenses within the lake sediments are as thick as 25 feet (Nyman and Pettijohn 1971, p. 4). The locations of major valley train and outwash aquifers and of till and lake deposits, where isolated sand and gravel aquifers can be found, are shown on the adjacent map of glacial geology (fig. 3.1a).

In the glaciated area, bedrock aquifers are used where till is too thin to contain adequate sand and gravel lenses or where outwash aquifers are not present. Although the unglaciated area contains some outwash and lake deposits, the bedrock is generally the only ground-water source. The areal extent and the stratigraphic relationships of bedrock in Area 32 are shown in the bedrock-outcrops map (fig. 3.1b) and in the geologic column (fig. 3.1c), respectively.

Limestone and sandstone of Mississippian age are sources of small ground-water supplies. The Chesterian Series, especially the Stephensport and West Baden Groups, consist of porous sandstone and limestone interbedded with impermeable shale. These aquifers can maintain small-yield wells. The underlying Blue River and Sanders Groups are dense, fractured limestones. The dense limestone is not an aquifer, but water can be removed from crevices and solution cavities. The fine-grained rocks of the Borden Group transmit little water, and the 1 to 10 feet thick jointed Rockford Limestone lies between impermeable layers of rock. According to Harrell (1935, p. 88-89), the Borden Group and the Rockford Limestone are not aquifers; nor is a small outcrop of New Albany Shale at the northern tip of Area 32.

Small ground-water supplies can generally be developed anywhere in the Pennsylvanian outcrop area. Discontinuous confining layers downdip from the outcrop areas can limit recharge and reduce yield. The Mansfield Formation, Merom Sandstone Member of the Mattoon Formation, and Busseron Sandstone Member of the Shelburn Formation, as well as other sandstones, are generally good aquifers, except under these confining conditions. In coal-seam aquifers, clay layers beneath the coal allow water to collect in the coal joints and crevices (Harrell, 1935, p. 74-76). 


\section{EXPLANation}

$\sum$ Conemaughian Series

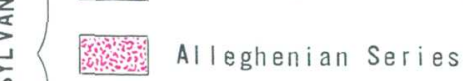

竞 $\square$ Pottsvillian Series

$\frac{z}{2}(\mathbb{N}$ Chester Series

Blue River and
Sanders Group

$\bar{s} \begin{aligned} & \text { Borden Group and } \\ & \bar{s} \\ & \text { Rockford Formatio }\end{aligned}$

$\frac{\sum^{\frac{1}{2}}}{\frac{2}{a}}$

New Albany Shale

$\stackrel{2}{=}$ $39^{\circ} 30^{\prime} \mathrm{A}$

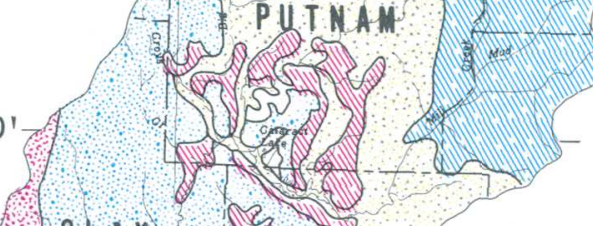

clar. 0 ?
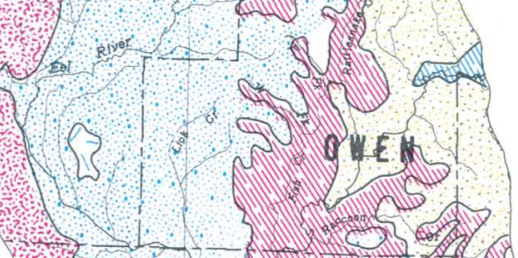

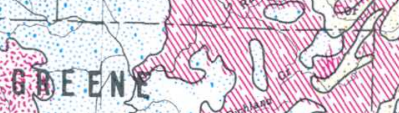

(2) 3 . 1 .

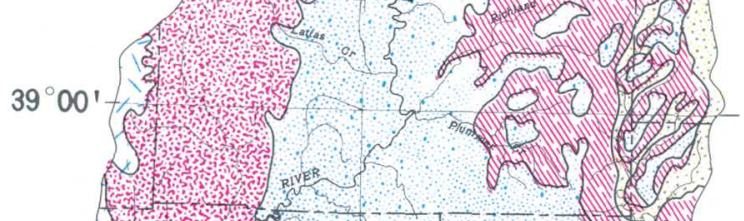

n. 7 . 25 .

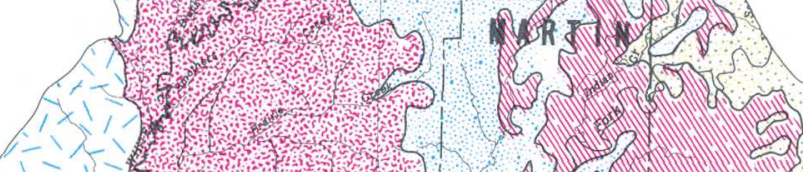

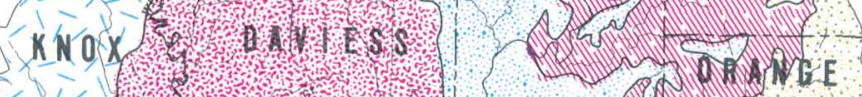

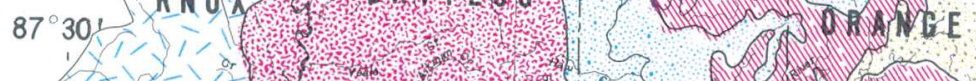

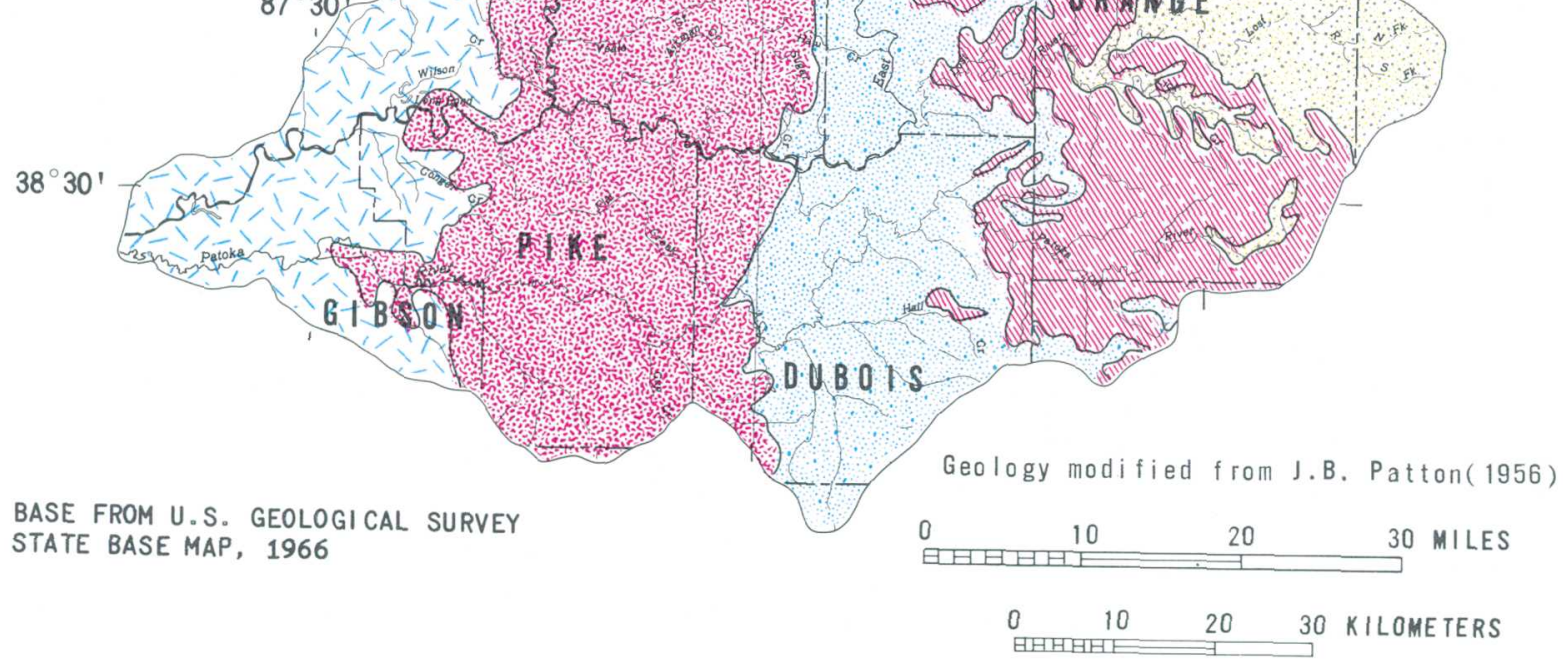

Figure 3.1b. -- Bedrock outcrops.

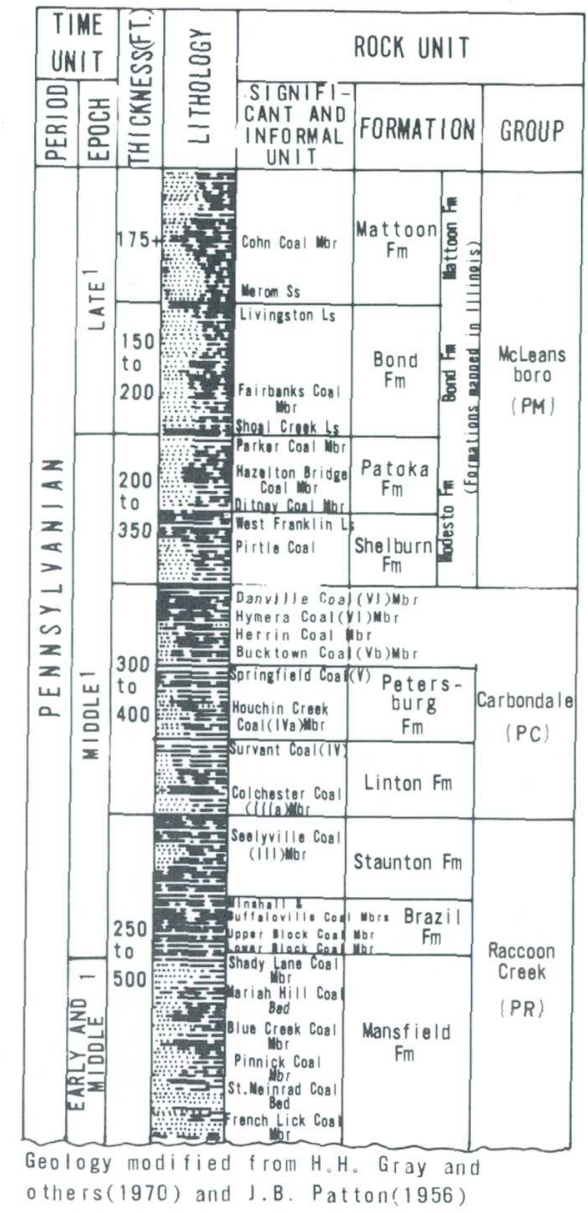

Usage of U.S. Geological Survey,

all other usage is
Geological Survey

Figure 3.1c. -- Geologic column.

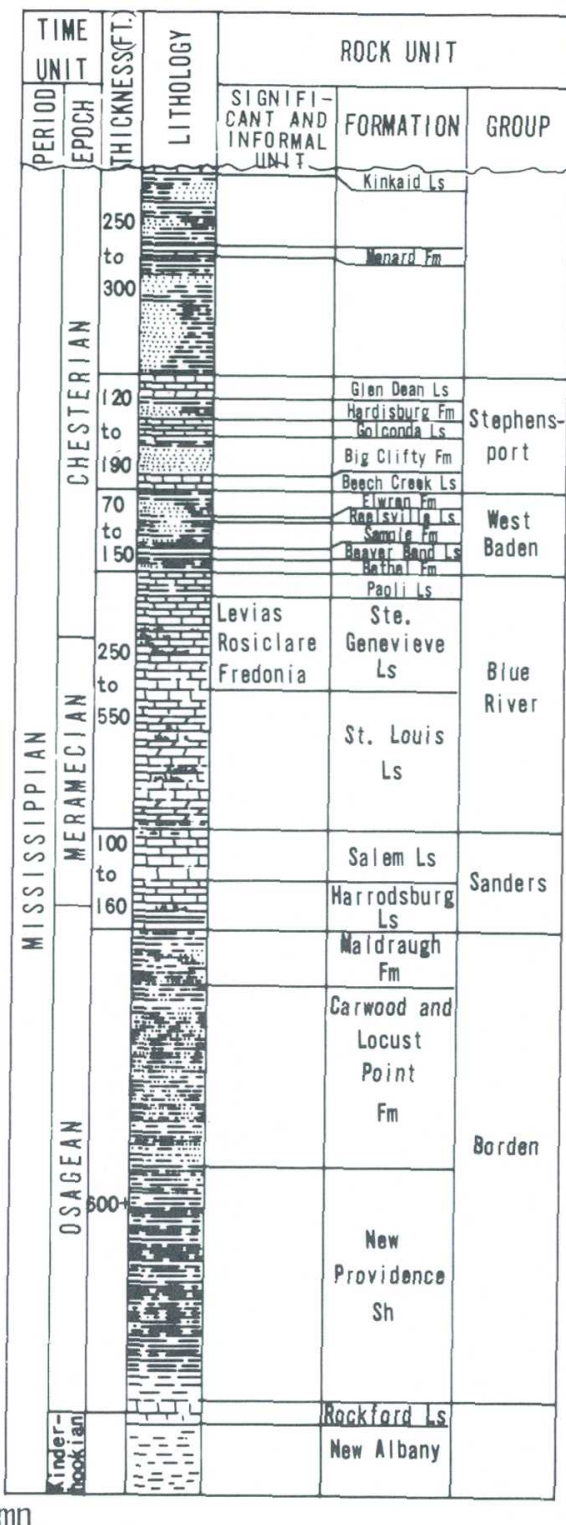

$$
39^{\circ} 00^{\prime}
$$

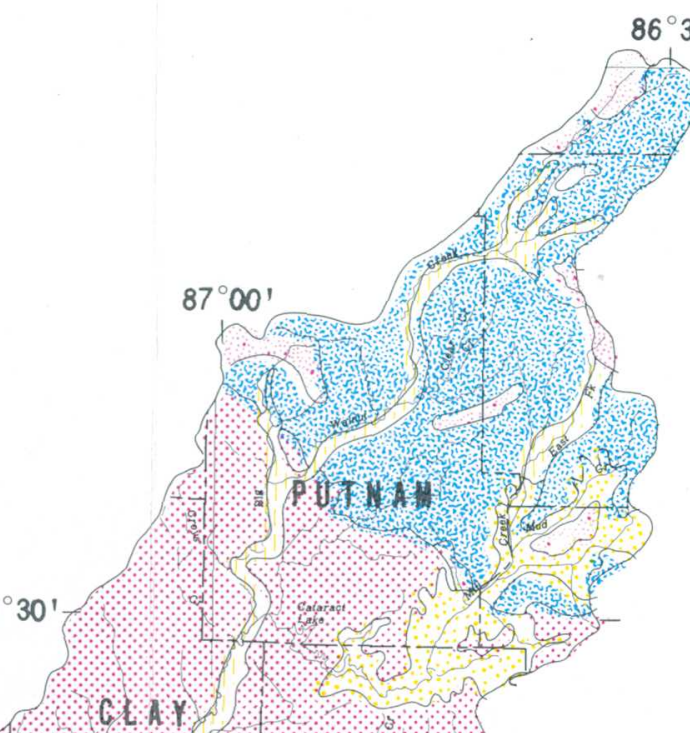

(n)

is

(1)

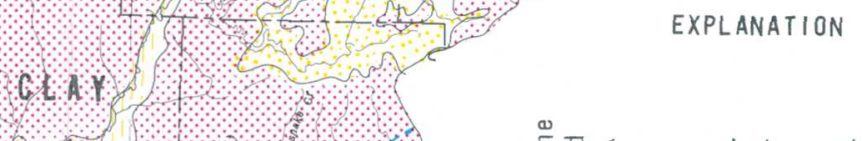

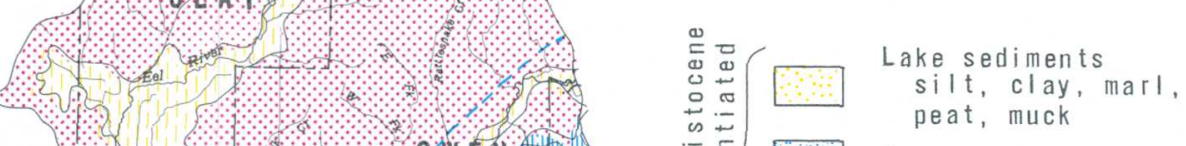

Dune sand

Dand

Valley train and sand and grave

$\square \begin{gathered}\text { End moraine } \\ \text { mostly till }\end{gathered}$

Ground moraine

m prift

Buried boundary

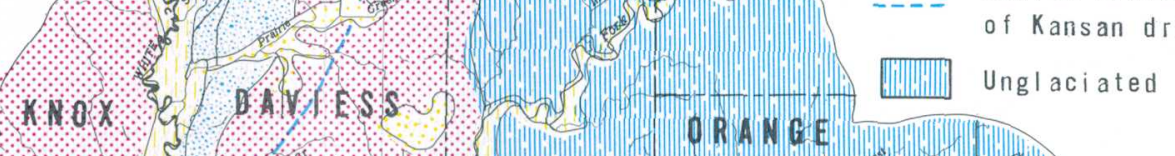

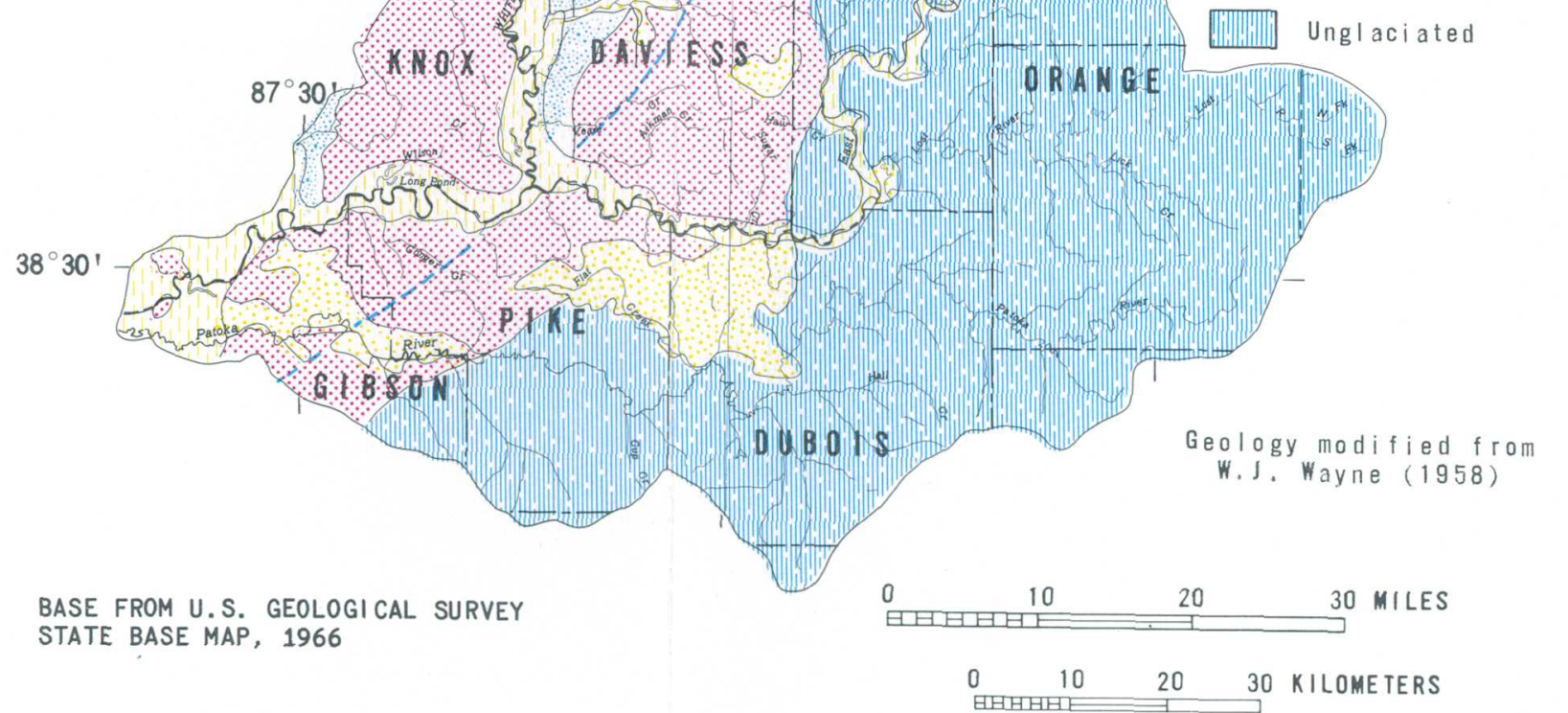

Figure 3.1a.-- Glacial geology 


\title{
GROUND-WATER DEVELOPMENT POTENTIAL OF THE GLACIAL AND THE BEDROCK AQUIFERS DEPENDS ON SEVERAL VARIABLES
}

\author{
High-yield water wells can usually be developed in glacial sand and \\ gravel deposits because of their high hydraulic conductivity \\ and recharge rates. Valley train and outwash deposits have \\ greater development potential than aquifer lenses confined \\ in till or lake sediments. Yields from bedrock aquifers \\ are usually small, but the aquifers are areally extensive.
}

Ground-water development potential of glacial and bedrock aquifers depends on thickness, areal extent, permeability, and recharge. Bedrock aquifers underlie nearly all parts of the study area but have a lower development potential than the more localized glacial sand and gravel aquifers.

Valley train and outwash deposits have the highest potential for ground-water development and can support some industrial and municipal supplies, where wells yield 1,000 gallons per minute or more. These aquifers, as thick as 100 feet, are the most areally extensive sand and gravel deposits. The hydraulic conductivity of these aquifers is typically $2,000(\mathrm{gal} / \mathrm{d}) / \mathrm{ft}^{2}$. Recharge, directly from precipitation or seepage from valley walls, is estimated to be $350,000(\mathrm{gal} / \mathrm{d}) / \mathrm{mi}^{2}$ for unconfined aquifers and 125,000 for those confined under till or lake sediments (Nyman and Pettijohn, 1971, p. 4, 5, 10).

Many sand and gravel lenses confined in till or lake deposits have high yields but low development potential. The hydraulic conductivity of these deposits is probably about the same as that of the valley train aquifers $\left[2,000(\mathrm{gal} / \mathrm{d}) / \mathrm{ft}^{2}\right]$, but their thickness (as much as 25 feet) and areal extent are much less. Recharge is probably even less than for confined valley train or outwash deposits $\left[125,000(\mathrm{gal} / \mathrm{d}) / \mathrm{mi}^{2}\right]$ because all recharge travels vertically through the confining materials. Wells in these aquifers typically yield from 50 to 500 gallons per minute (Nyman and Pettijohn, 1971, p. 4).
Some wells in sandstone and coal of Pennsylvanian age can produce 20 gallons per minute but generally produce less than 10 . The basal sandstone of the Mansfield Formation can produce as much as 100 gallons per minute in localized areas (Clark, 1980 , p. 28). Supplies of ground water for domestic use can be developed almost anywhere in the Pennsylvanian outcrop area (Harrell, 1935, p. 75). Hydraulic conductivity of Pennsylvanian aquifers is typically $25(\mathrm{gal} / \mathrm{d}) / \mathrm{ft}^{2}$. Recharge amounts to about 60,000 (gal/d)/ $\mathrm{mi}^{2}$ (Nyman and Pettijohn, 1971, p. $5,10)$. Precipitation recharges the aquifers at their outcrops, either directly or by percolation through glacial deposits (Cable and others, 1971, p. 5).

Limestone and sandstone aquifers of Mississippian age are similar to aquifers of Pennsylvanian age in hydraulic conductivity and recharge. The Upper Mississippian sandstones of the Chesterian Series generally yield less than 5 gallons per minute, and the dense, fractured limestones of the Blue River and Sanders Groups usually yield less than 10 gallons per minute but in small areas yield more than 100 (Clark, 1980, p. 28).

The maximum well yield that can be expected in a particular area is shown on the adjacent map (fig. 3.2). This generalized map is representative of all aquifers, glacial and bedrock. 


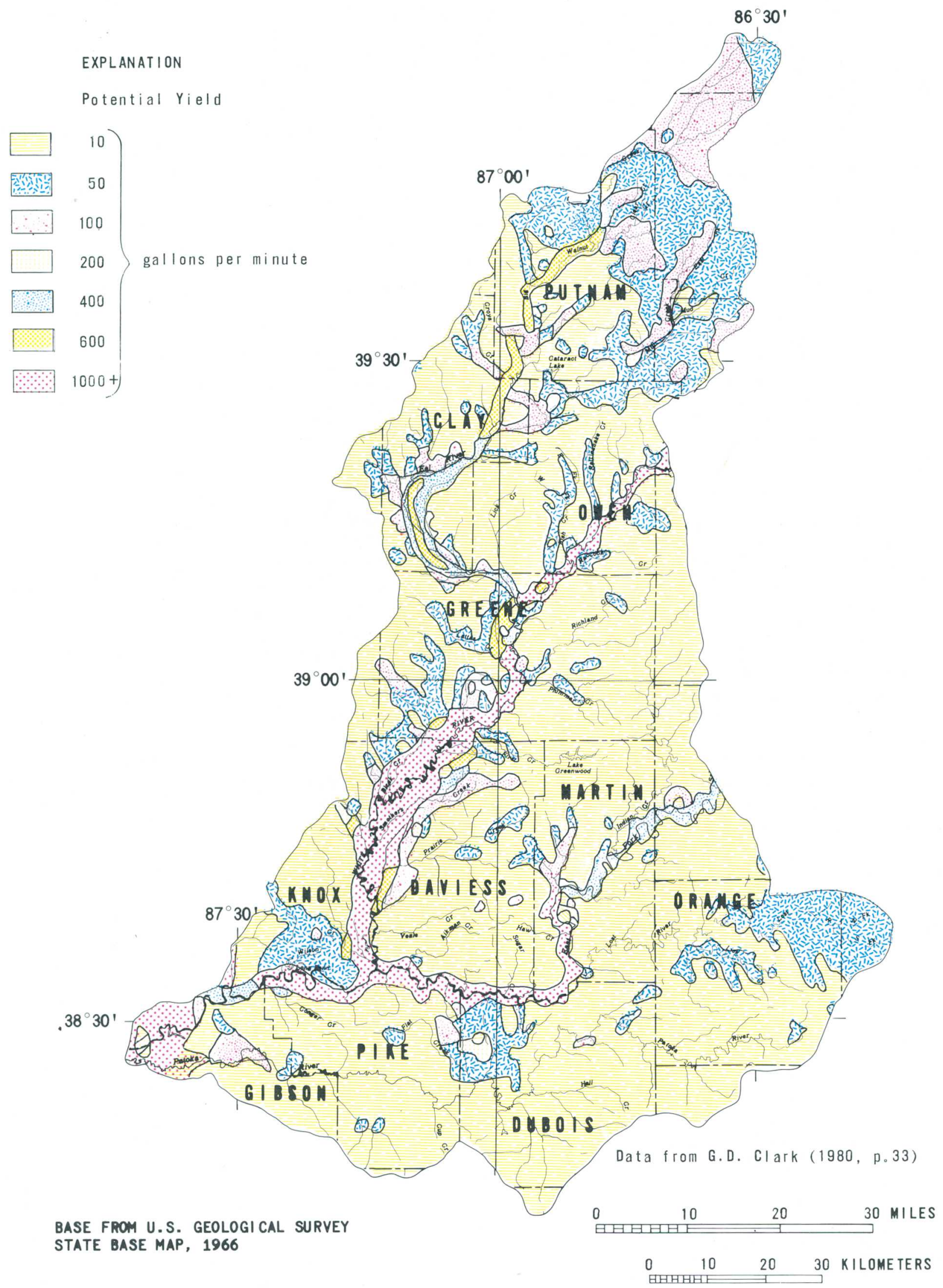

Figure 3.2. - Ground-water potential. 


\title{
3.0 GROUND-WATER SYSTEM \\ 3.3 Ground-Water Flow and Water Levels
}

\section{MAJOR STREAMS INFLUENCE GROUND-WATER FLOW, AND WATER LEVELS FLUCTUATE SEASONALLY}

\author{
Ground-water flow is part of a regional flow system in the Wabash River \\ basin. The source of ground water is precipitation percolating \\ into the aquifers. Ground water leaves aquifers as seepage into \\ streams, evapotranspiration, and pumpage. Water levels fluctuate \\ seasonally in a regular pattern but can be influenced by prolonged \\ variations from normal precipitation.
}

In general terms, the Wabash River basin (fig. 3.3a) is a single hydrologic unit. Precipitation percolates through till, sand, gravel, and bedrock and flows through the aquifers toward streams. Ground water leaves the system as seepage into the streams, evapotranspiration, or pumpage (Nyman and Pettijohn, 1971, p. 12).

Ground-water flow patterns are affected by the major streams in the Wabash River basin. Three drainage subbasins are delineated in figure 3.3b. Glacial aquifers discharge water into these streams by seepage. Bedrock aquifers, where cut by stream valleys, discharge water by seepage or springs. $\mathrm{Al}$ though flow in the bedrock is locally toward a major stream, there is also a regional component of flow downdip in the Illinois structural basin.

The natural rate of ground-water seepage can be measured in a stream at base flow. This rate of seepage is related to aquifer transmissivity and the head differential between aquifer and stream (Nyman and Pettijohn, 1971, p. 5). Glacial aquifers in Area 32 usually discharge more than the bedrock aquifers. Also, Corbett (1965, p. 2) observed that cast overburden resulting from coal strip mining in the Patoka River basin produces significant discharge compared with little or no discharge in the undisturbed areas.
Water levels in the study area are recorded continuously in four observation wells whose locations are shown on the study area map (fig. 3.3b). Historic data from these wells are available at the Geological Survey office in Indianapolis and are published annually in "Water Resources Data for Indiana" beginning with the 1975 water year (U.S. Geological Survey, 1976-79). Each well is set in a different aquifer, and all the wells except PN4 are artesian. HD4 is 85 feet deep and is cased to 70 feet in Mississippian sandstone. MT5 is 143 feet deep and is cased to 53 feet in Pennsylvanian sandstone. OW7 is 150 feet deep and is cased to 15 feet in Mississippian limestone. PN4 is 60 feet deep and is cased to 20 feet in Holocene sand and gravel deposits (U.S. Geological Survey, 1979, p. 359, 365, 369, 372).

Ground-water levels fluctuate seasonally, high levels in the spring and low levels in the fall. Increased precipitation and decreased evapotranspiration in the fall cause levels to rise again. Hydrographs of four wells (fig. 3.3c) show the general pattern of fluctuation for the 1976 and 1978 water years but an anomalous pattern for the 1977 water year. A drought in late 1976 caused the lowest water levels in 20 years, but increased precipitation in 1977 caused water levels to rise and resume the typical fluctuation pattern (Clark, 1980, p. 34-35). 

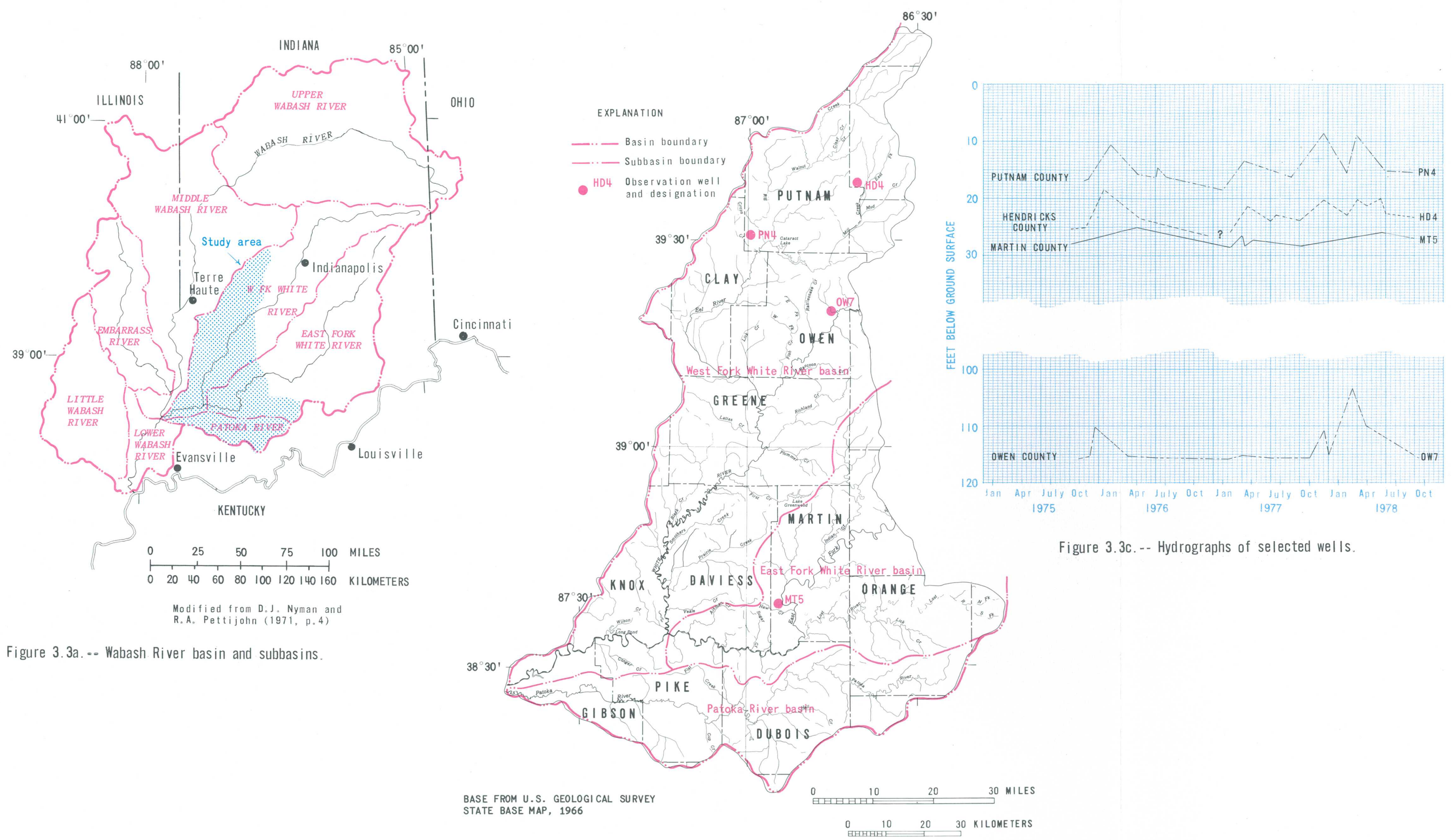

Figure 3.3b. - Subbasins of the Wabash River basin within the study area 


\title{
4.0 WATER QUALITY \\ 4.1 Surface Water \\ 4.1.1 Introduction
}

\section{WATER-QUALITY DATA ARE REQUIRED FOR COAL-MINING PERMIT APPLICATIONS}

\author{
Section 507(b)(11) of the Surface Mining Control and Reclamation Act requires that \\ extensive information about the probable hydrologic consequences of mining and \\ reclamation be included in permit applications. Water-quality data are essential \\ hydrologic information in making such applications. As a minimum, water-quality \\ constituents and properties to be monitored are dissolved solids, suspended \\ solids, acidity, $\mathrm{pH}$, total iron, dissolved iron and total manganese.
}

Surface mining and reclamation have seriously affected surface-water quality in much of the United States, and their impact, especially in coal-mining areas, is well documented (Dyer and Curtis, 1977; Hoehn and Sizemore, 1977; King and others, 1974; and Letterman and Mitsch, 1978). Because of the oxidation and the weathering of pyrite and marcasite exposed by mining operations, drainage in many old mining areas has an acidic $\mathrm{pH}(<7)$. In Indiana, these areas were mined before passage of the Indiana Reclamation Law of 1968 (Indiana Code 13-46), which mandates that spoil piles be graded and a cover crop be established. Although acid mine drainage has been reduced by current mining operations as a result of the preferential burial of pyrite, acidic drainage from the old mining operations continues to be a water-quality problem.

Acid mine drainage is not the only water-quality problem. Concentrations of many dissolved and suspended constituents, including iron and aluminum, are higher in both old and new mining areas than in natural water. Erosion from unreclaimed areas of old mines or unvegetated areas of new mines can substantially increase sediment loads in streams (Dyer and Curtis, 1977).

Few water-quality data are available for the coal-mining region of southwestern Indiana. The need for these data has become critical since enactment of the Surface Mining Control and Reclamation Act of 1977. Section 507(b)(11) of the Act requires that extensive information about the probable hydrologic consequences of mining and reclamation be included in permit applications so that the regulatory authority can determine the probable cumulative impact of mining on the hydrology of the area. Hydrologic information on the general area is to be made available to applicants for mining permits from an appropriate Federal or State agency before mining permits are issued. The Act provides little information on water-quality constituents and properties that should be monitored. Paragraph 779.16 of the Federal regulations concerning reclamation (Office of Surface Mining, 1979) states that, in general, local water-quality standards are applicable, but, as a minimum, impact determinations should consider the following: (1) dissolved solids, (2) suspended solids, (3) acidity, (4) $\mathrm{pH}$, (5) total and dissolved iron, and (6) total manganese. Other water-quality properties or constituents that might be affected by surface mining include specific conductance, alkalinity, sulfate, and aluminum.

Dissolved and suspended solids affect water adversely in several ways: (1) Water with a high dissolved-solids concentration generally does not taste good and may cause unfavorable physiological reactions in some people; (2) highly mineralized water requires costly chemical treatment before domestic and some industrial uses; (3) water with high suspended-sediment concentrations is unsatisfactory for bathing and recreation; (4) suspendedsediment particles adsorb and transport metal ions, pesticides, and nutrients in streams; (5) high sediment loads in streams can adversely affect the biological communities in streams; and (6) sediment loads deplete the storage capacity of reservoirs, reduce river-channel capacities, and may increase the frequency of flooding and the flood stages.

Specific conductance is a measure of the ability of water to conduct an electrical current. The magnitude of specific conductance depends on the total concentration of ionized substances in the water and the water temperature at which the measurement is 
made. Specific conductance is often used as an indicator of the dissolved-solids concentration of water.

The $\mathrm{pH}$ of a solution refers to its hydrogen ion activity and is expressed as the logarithm of the reciprocal of the hydrogen ion activity in moles per liter at a given temperature. The $\mathrm{pH}$ of most surface waters in the United States is within the range from 6.5 to 8.5 (Hem, 1970, p. 93). Most streams in the study area are slightly basic ( $\mathrm{pH}>7.0)$ because of their carbonate and bicarbonate concentrations. A departure from the normal $\mathrm{pH}$ can be caused by acidic or alkaline industrial wastes, coal-mine wastes, or, for poorly buffered waters, fluctuations in algal photosynthesis.

Acidity is the capacity of a solution to neutralize a strong base (American Public Health Association and others, 1976, p. 273). It is a measure of a gross property and can be interpreted in terms of specific substances only when the chemistry of the sample is known. Strong mineral acids such as sulfuric, weak acids such as carbonic and acetic, and hydrolyzing salts such as ferrous or aluminum sulfates may contribute to the measured acidity, depending on the method of determination. The acidity of water is important because acids corrode metals and influence certain chemical and biological processes.

Alkalinity of water is its quantitative capacity to neutralize an acid. Because the alkalinity of surface water is primarily due to the carbonate and bicarbonate ions (Hem, 1970, p. 152), alkalinity is an indication of the concentrations of these constituents. Alkalinity may also include borate, hydroxide, phosphate, or silicate.
Iron and manganese are common components of rocks and soils and, in water, may originate from leaching of rocks and minerals. Other sources of these elements in water include industrial wastes, municipal wastes, corroded metal, and mine drainage.

Uncomplexed iron in equilibrium with atmospheric oxygen is extremely insoluble. Therefore, in most water, soluble iron is a complexed ion. Manganese in water may be in solution in the divalent state, or as a stable, soluble complex in the trivalent state, or in suspension in the quadrivalent state (Hem, 1970, p. 129).

Iron and manganese concentrations of less than 1 $\mathrm{mg} / \mathrm{L}$ are nontoxic to freshwater aquatic life (U.S. Environmental Protection Agency, 1976, p. 152, and McKee and Wolf, 1963, p..215, respectively) and are essential to certain physiological functions. The iron and manganese concentration limits recommended for drinking water by the U.S. Environmental Protection Agency (1976) are based on the tendency of these elements to stain clothing and plumbing. In addition, iron can impart a bittersweet astringent taste to water, detectable by some persons at concentrations greater than 1 or $2 \mathrm{mg} / \mathrm{L}$ (American Public Health Association and others, 1976, p. 207).

Sulfate is widely distributed in nature and may be present in natural water in concentrations ranging from a few to several thousand milligrams per liter. Mine-drainage wastes may contribute high sulfate concentrations to streams as a result of the oxidation of pyritic material. 


\author{
4.0 WATER QUALITY \\ 4.1 Surface Water \\ 4.1.2 Regional Water-Quality Trends
}

\title{
STATISTICAL ANALYSIS SYSTEM (SAS) USED IN ANALYSIS OF REGIONAL WATER-QUALITY TRENDS
}

\author{
Water-quality data collected by the Geological Survey, U.S. Army Corps \\ of Engineers, and the Indiana State Board of Health were compiled \\ from WATSTORE and STORET files and were analyzed by the univariate \\ program in the Statistical Analysis System. ${ }^{1}$
}

\begin{abstract}
Water-quality data on file in the WATSTORE and STORET computer data bases for stations in or near the study area were retrieved for analysis by a retrieval system that uses latitude and longitude as the corners of a polygon. Some stations are just outside the study area but their data were used in the statistical analyses. Water-quality constituents and properties for which data were retrieved include total and dissolved iron, total and dissolved manganese, sulfate, alkalinity, specific conductance, and $\mathrm{pH}$. The average value for each constituent and property at a sampling station (except $\mathrm{pH}$ ) was determined. For stations where only one measurement was available, this measurement was assumed to represent the average value for that station, except for $\mathrm{pH}$ where the measurement was assumed to represent the median $\mathrm{pH}$. These averages and medians were used for regional comparisons. The median of the station averages were used as a basin descriptor and is reported as median average. Average values were divided into six categories on the basis of a percentile distribution: values less than the 10th percentile; values from the 10th through the 25 th percentiles, from the 26th through the 50th percentiles, from the
\end{abstract}

51 st through the 75 th percentiles, from the 76th through the 90th percentiles; and values greater than the 90th percentile. Percentile distribution was also used for $\mathrm{pH}$, except that median values rather than averages were determined for all data collected at an individual station.

Stations used in the analyses are located on the adjoining map (fig. 4.1.2). Latitude and longitude of all stations having data stored in WATSTORE and STORET, the county where each station is located, the agency responsible for sample collection, and the number of observations for each water-quality constituent measured are listed in Appendix 2. The station identification number listed in the table and shown on the map is a numerical listing of all stations retrieved from WATSTORE and STORET files. This number may be different from the identification number used by other authors when describing the same point. The reader should be aware that the data in the table apply only to the corresponding number on the map in this section and should not be transferred to other sections of this report.

\footnotetext{
${ }^{1}$ Barr and others, 1979. (The use of the computer program name in this report is for identification purposes only and does not imply endorsement by the U.S. Geological Survey.)
} 


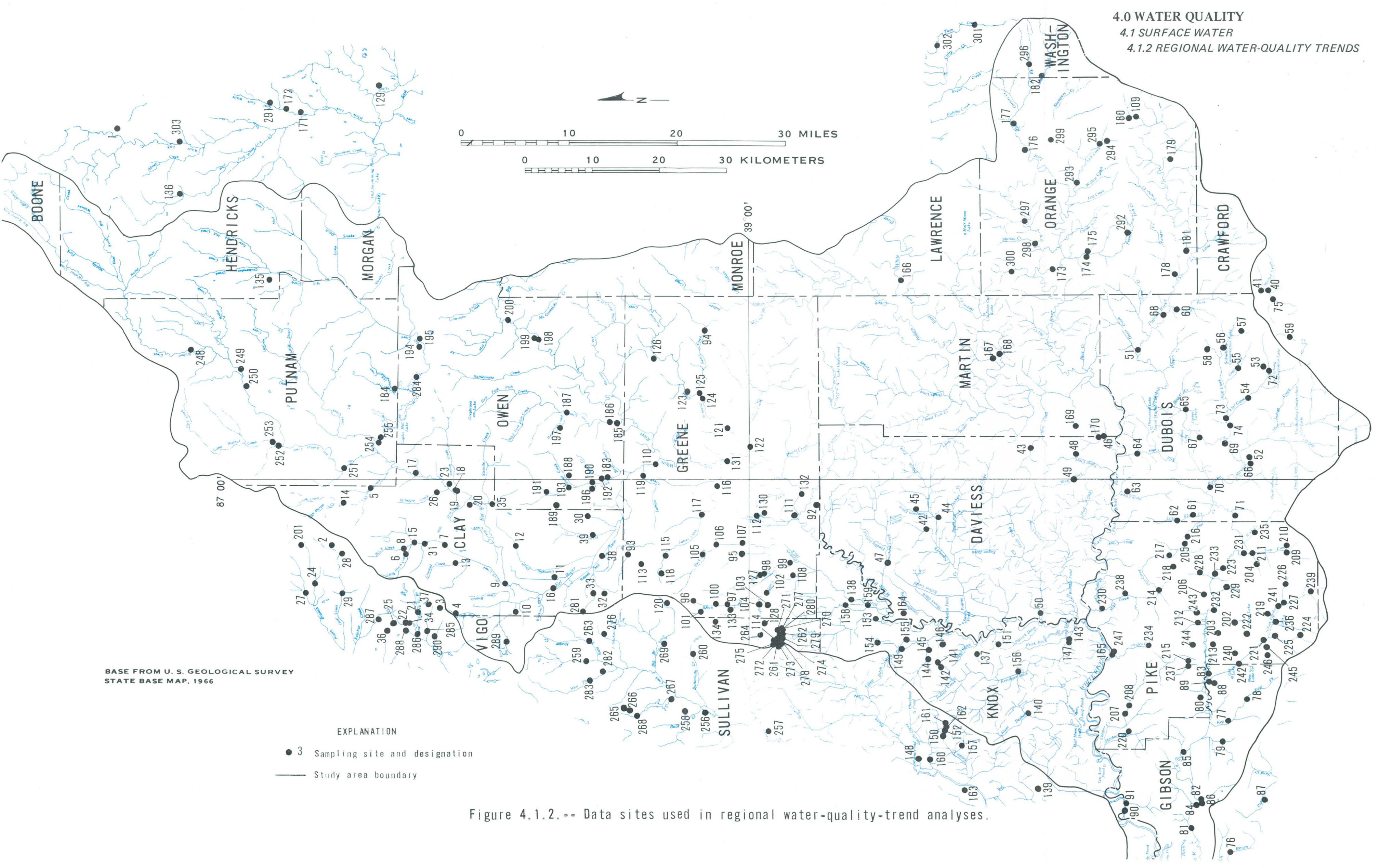




\author{
4.0 WATER QUALITY \\ 4.1 Surface Water \\ 4.1.2 Regional Water-Quality Trends \\ 4.1.2.1 $\mathrm{pH}$
}

\title{
REGIONAL WATER-QUALITY TRENDS IN pH
}

\author{
The median pH of the medians at 293 stations in or near Area 32 was \\ 7.4 , and the range in median $\mathrm{pH}$ was from 2.4 to 8.9 .
}

\begin{abstract}
Values of $\mathrm{pH}$ were generally less than 7.4 in the southwest part of the study area, principally in Greene, Knox, and Pike Counties, where mining has been concentrated. No other trends in $\mathrm{pH}$ were apparent. Surface waters in the west part of the study area are primarily representative of the glaciated Wabash Lowland physiographic unit. Surface water in the east part of the study area is primarily representative of the unglaciated Crawford Upland physio-
\end{abstract}

graphic unit. Surface-mining activity in the southwest area, before present-day reclamation techniques were instituted, may be the cause of the $\mathrm{pH}$ less than 6. Hydrogen ions formed by exposure and oxidation of pyrite and marcasite may lower the $\mathrm{pH}$ of surface water (Hem, 1970, p. 162). The median $\mathrm{pH}$ at the 293 sites sampled was grouped into six ranges by percentile and are presented in figure 4.1.2.1. 
EXPLANATION

PERCENTILE

$\begin{array}{lll}\leq 10 & <6.0 \\ \Delta \quad 11-25 & 6.0-7.0 \\ \quad 26-50 & 7.0-7.4 \\ \circ \quad 51-75 & 7.4-7.8 \\ \Delta \quad 76-90 & 7.8-8.0 \\ \diamond \geq 91 & >8.0\end{array}$
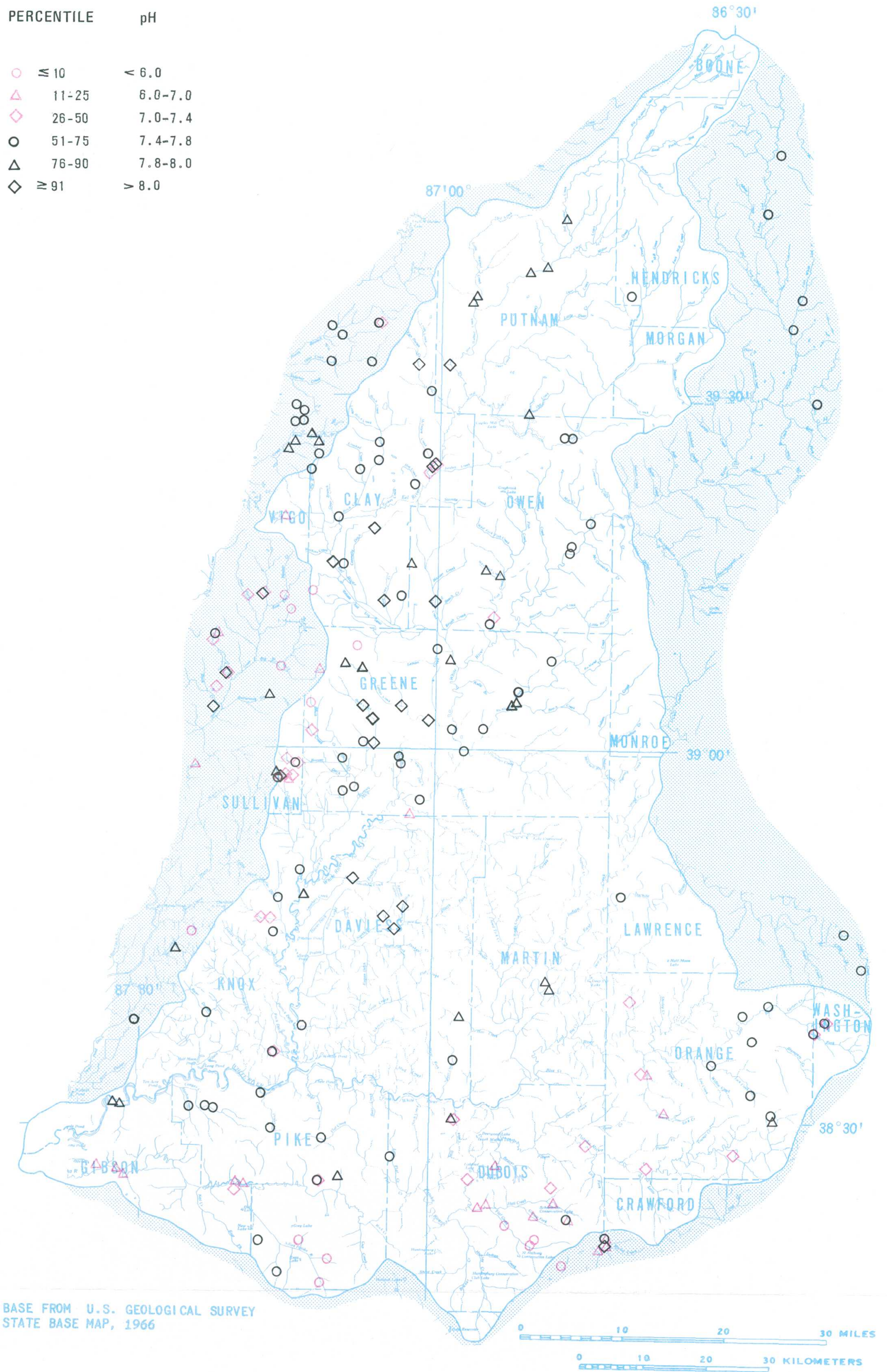

Figure 4.1.2.1. -- Ranges of median $\mathrm{pH}$ values. 


\subsection{WATER QUALITY \\ 4.1 Surface Water \\ 4.1.2 Regional Water-Quality Trends \\ 4.1.2.2 Alkalinity}

\section{REGIONAL WATER-QUALITY TRENDS IN ALKALINITY CONCENTRATION}

\section{The median of average alkalinity for samples from 153 stations in or near the study Area 32 was $143 \mathrm{mg} / \mathrm{L}$ as calcium carbonate. The average alkalinity ranged from 0 to $468 \mathrm{mg} / \mathrm{L}$.}

\begin{abstract}
Alkalinity of surface water was generally lower in the west part of the study area than in the east. Like $\mathrm{pH}$, the alkalinity is probably affected by the amount and the extent of surface mining as well as the surficial and bedrock geology of the region. The
\end{abstract}

average alkalinity of water samples was grouped into six ranges by percentile, which are presented in figure 4.1.2.2. 
EXPLANATION

\begin{tabular}{|c|c|c|}
\hline \multicolumn{2}{|c|}{ PERCENTILE } & $\begin{array}{l}\text { MILLIGRAMS } \\
\text { PER LI TER } \\
\text { AS } \mathrm{CaCO}_{3}\end{array}$ \\
\hline 0 & $\leq 10$ & $<23$ \\
\hline$\Delta$ & $11-25$ & $23-71$ \\
\hline$\diamond$ & $26-50$ & $71-143$ \\
\hline & $51-75$ & $143-187$ \\
\hline & $76-90$ & $187-248$ \\
\hline & $\geq 91$ & $>248$ \\
\hline
\end{tabular}




\title{
4.0 WATER QUALITY \\ 4.1 Surface Water Quality \\ 4.1.2 Regional Water-Quality Trends \\ 4.1.2.3 Specific Conductance
}

\section{REGIONAL WATER-QUALITY TRENDS IN SPECIFIC CONDUCTANCE}

\author{
The median of average specific conductance for samples from 286 stations \\ in or near Area 32 was $615 \mu \mathrm{mhos} / \mathrm{cm}$ at $25^{\circ} \mathrm{C}$. Average specific \\ conductance ranged from 39.5 to $8,960 \mu \mathrm{mhos} / \mathrm{cm}$ at $25^{\circ} \mathrm{C}$.
}

More coal has been mined in the west half of Area 32 than in the east half. Surface water in the west half of the study area is representative of the Wabash Lowland physiographic unit. Average specific conductance was generally higher in the west half of the study area than in the east half. Both the amount and the extent of surface mining, as well as the surficial and the bedrock geology of the region, seemed to affect specific conductance. Also, the dissolved-solids concentration is higher in the west half than in the east half, probably because the water in the west half contacts glacial overburden, which has a higher content of carbonate mineral species than the sandstone and the shale of the Crawford
Upland in the east half. Concentrations of most major dissolved constituents are higher in both old and new mining areas than in areas unaffected by mining. The higher concentrations account for at least some of the difference in specific conductance between the two halves. Without additional study, the relative contribution of dissolved ions from surficial deposits, bedrock, and surface mining activity cannot be determined. The average specific conductance for stations within the study area was grouped into six ranges by percentile, which are presented in figure 4.1.2.3. 
EXPLANATION

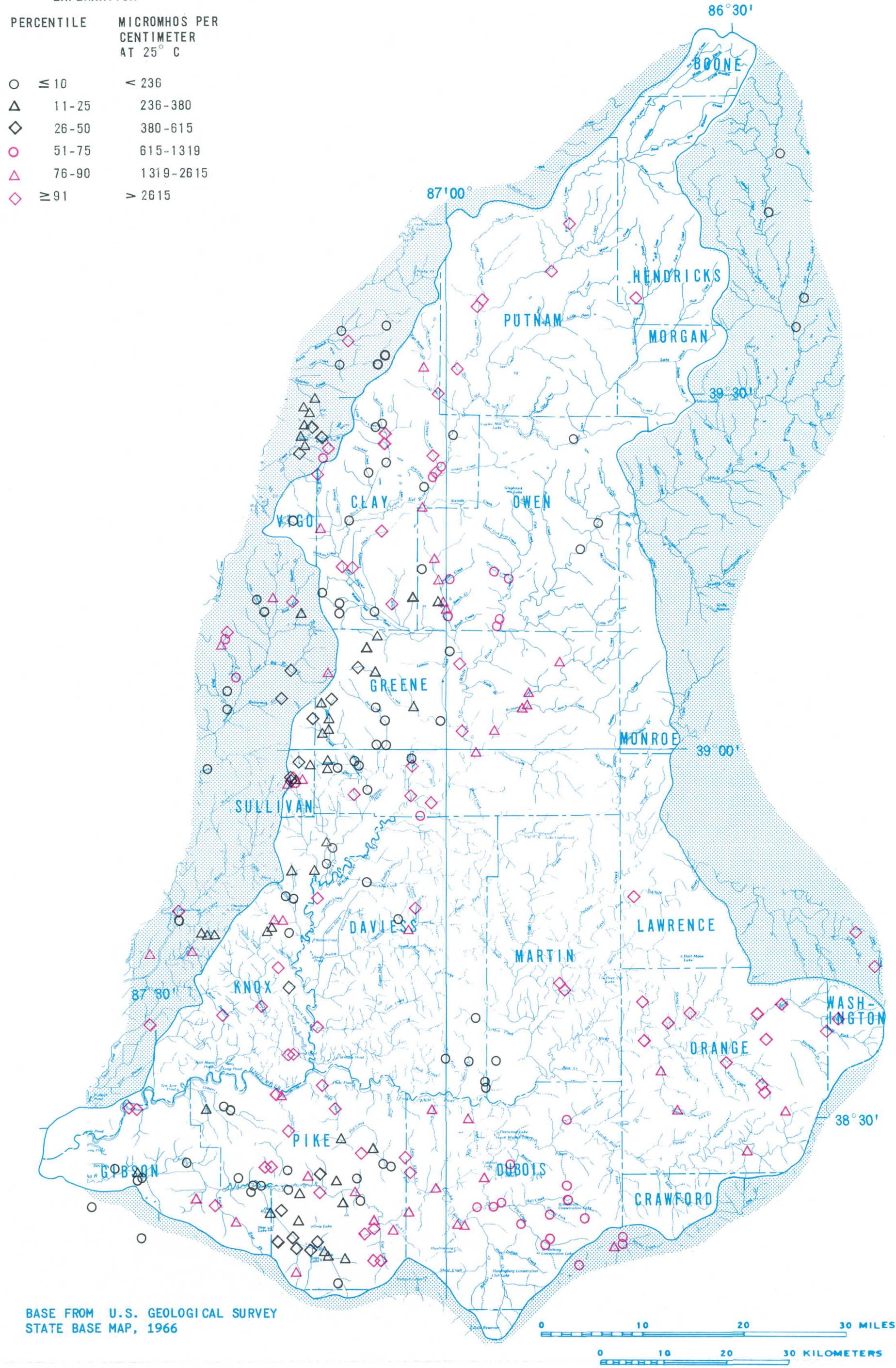




\author{
4.0 WATER QUALITY \\ 4.1 Surface Water \\ 4.1.2 Regional Water-Quality Trends \\ 4.1.2.4 Sulfate
}

\title{
REGIONAL WATER-QUALITY TRENDS IN SULFATE CONCENTRATION
}

\section{The median of average sulfate concentration for 145 stations sampled \\ in or near Area 32 was $65 \mathrm{mg} / \mathrm{L}$. The average sulfate concentration ranged from 2.4 to $6,230 \mathrm{mg} / \mathrm{L}$.}

Average sulfate concentration of surface water was higher in the west half of Area 32 than in the east half. Considerably more coal has been mined in the west half than in the east half. The higher sulfate concentrations in the west half of the study area may be the result of leaching of oxidized pyrite and mar- casite as a consequence of mining. During the oxidation, sulfate is produced $(\mathrm{Hem}, 1970$, p. 124 and 162). The average sulfate concentration for stations within the study area was grouped into six ranges by percentile, which are presented in figure. 4.1.2.4. 


\section{EXPLANATION}

\begin{tabular}{|c|c|c|}
\hline \multicolumn{2}{|c|}{ PERCENTILE } & $\begin{array}{l}\text { MILLI GRAMS } \\
\text { PER LITER }\end{array}$ \\
\hline 0 & $\leq 10$ & $<20$ \\
\hline$\Delta$ & $11-25$ & $20-30$ \\
\hline$\diamond$ & $26-50$ & $30-65$ \\
\hline 0 & $51-75$ & $65-1052$ \\
\hline$\Delta$ & $76-90$ & $1052-200$ \\
\hline$\diamond$ & $\geq 91$ & $>2000$ \\
\hline
\end{tabular}
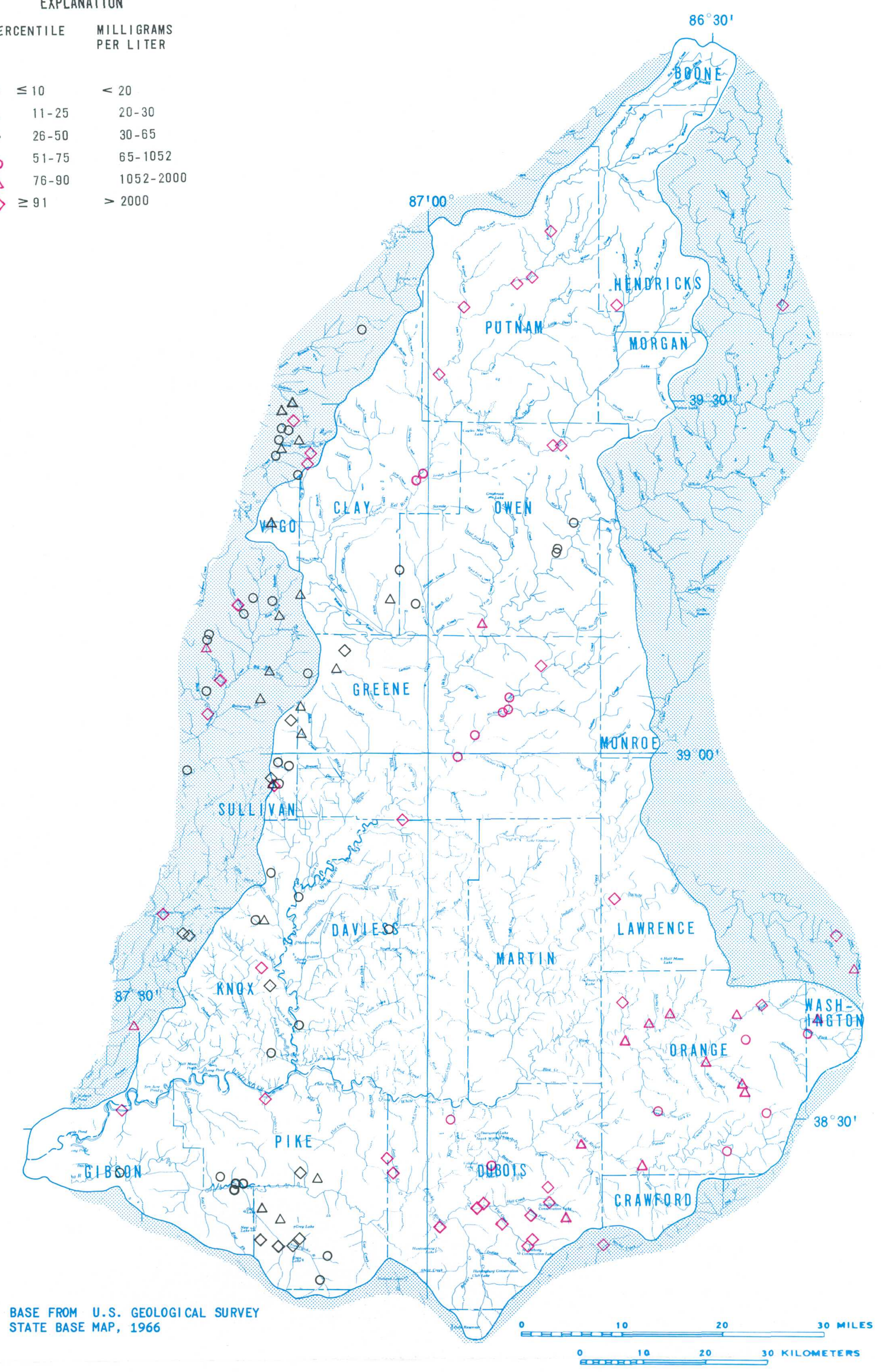

Figure 4.1.2.4. -- Ranges of average sulfate concentrations. 


\title{
4.0 WATER QUALITY \\ 4.1 Surface Water \\ 4.1.2 Regional Water-Quality Trends \\ 4.1.2.5 Total and Dissolved Iron
}

\section{REGIONAL WATER-QUALITY TRENDS IN TOTAL- AND DISSOLVED-IRON CONCENTRATIONS}

\author{
The median of average total iron concentration for samples from 100 \\ stations in or near Area 32 was $1.3 \mathrm{mg} / \mathrm{L}$. The average total-iron \\ concentration ranged from 0.03 to $2,300 \mathrm{mg} / \mathrm{L}$. The median \\ of average dissolved-iron concentration for samples from \\ 120 stations in or near the study area was $0.07 \mathrm{mg} / \mathrm{L}$. \\ The average dissolved-iron concentration ranged from \\ 0.01 to $255 \mathrm{mg} / \mathrm{L}$.
}

\begin{abstract}
Concentrations of total and dissolved iron were generally higher in the west half of Area 32 than in the east half, although data for dissolved iron were variable. This variability may be due to greater surface-mining activity in the west half. Concentration of iron in surface water has been increasing in both reclaimed and unreclaimed mining areas, prob-
\end{abstract}

ably because the water has been exposed to increasing amounts of weathered pyritic and marcasitic material. Average total- and dissolved-iron concentrations were grouped into six ranges by percentile, which are presented in figures $4 \cdot 1.2 .5 \mathrm{a}$ and $\mathrm{b}$. 


\section{EXPLANATION}

PERCENTILE MICROGRAMS

$0 \leq 10$

$\Delta \quad 11-25$

$235-56$

\begin{tabular}{l}
$\Delta 76-90 \quad 2955-26,44$ \\
\hline
\end{tabular}

$>26,444$

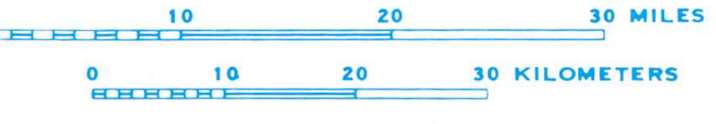

BASE FROM U.S. GEOLOGICAL SURVEY
STATE BASE MAP, 1966 .
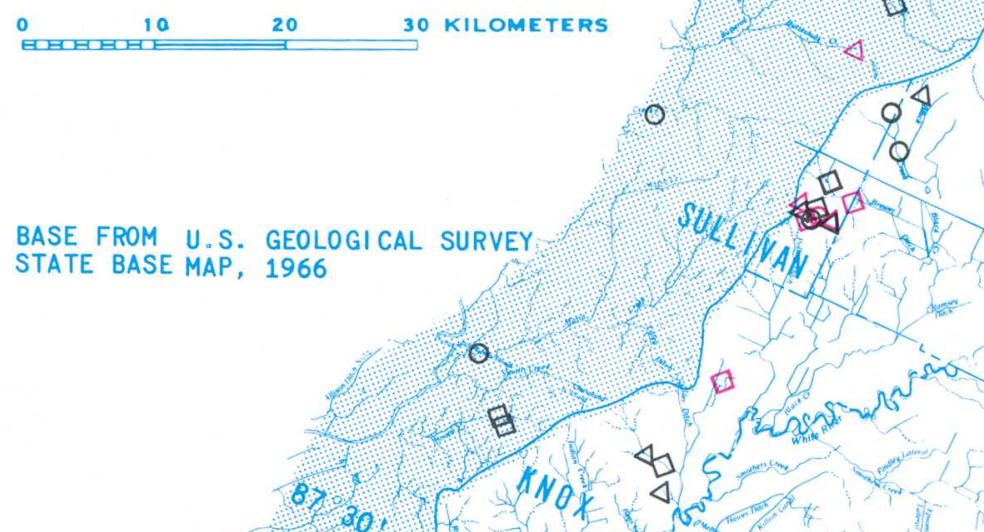

- 40

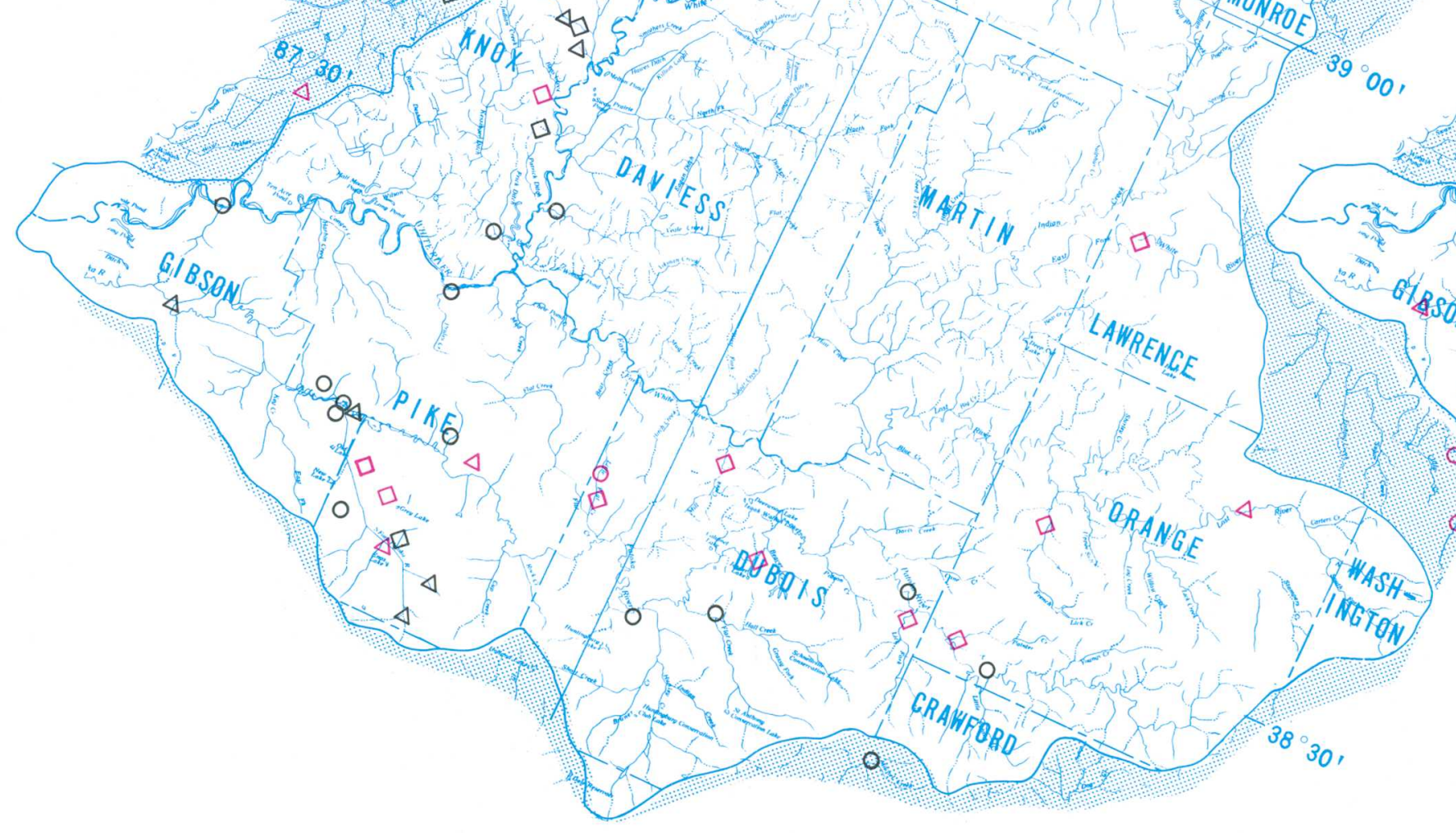

${ }^{M}$ PG $_{A}$

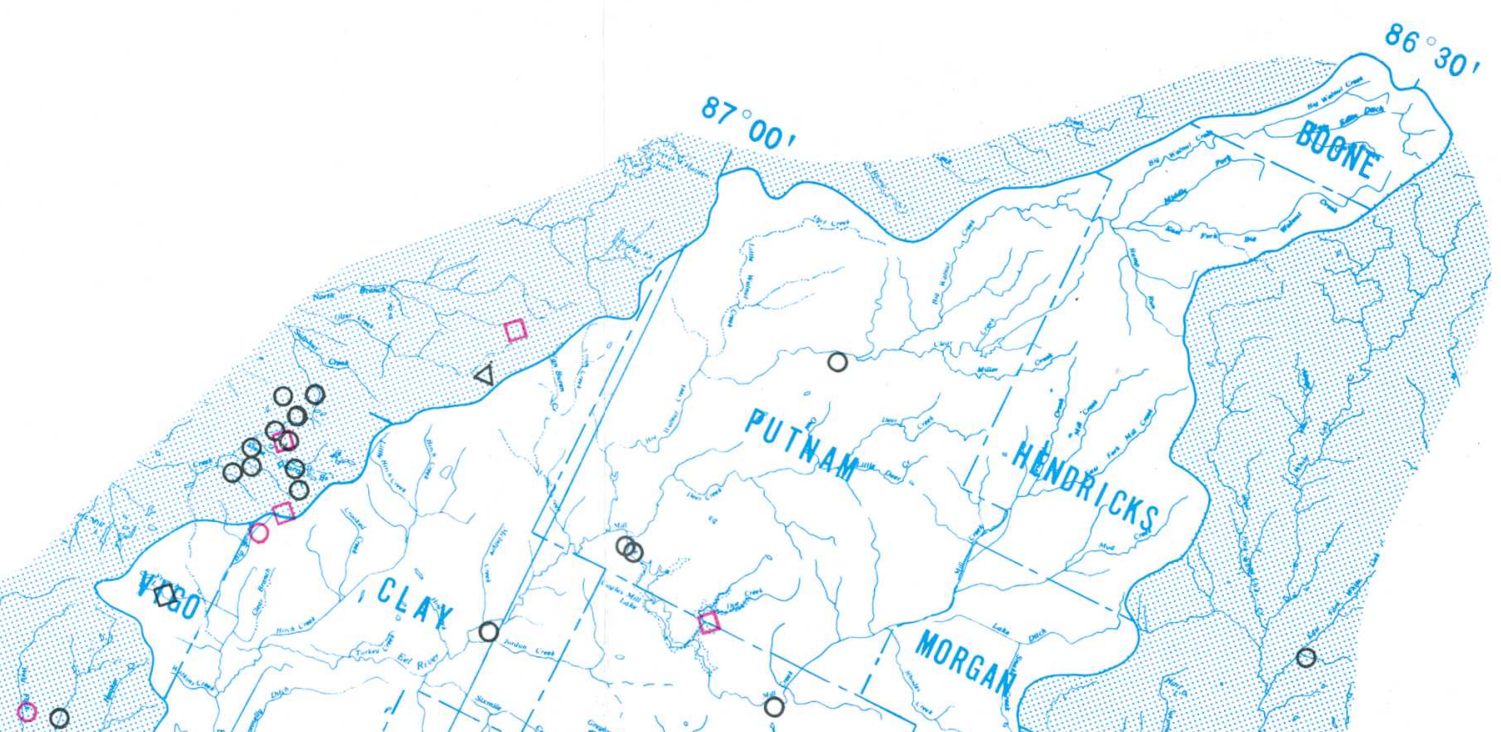




\author{
4.0 WATER QUALITY \\ 4.1 Surface Water \\ 4.1.2 Regional Water-Quality Trends \\ 4.1.2.6 Total and Dissolved Manganese
}

\title{
REGIONAL WATER-QUALITY TRENDS IN TOTAL- AND DISSOLVED-MANGANESE CONCENTRATIONS
}

\author{
The median of average total-manganese concentration for samples from \\ 98 stations in or near Area 32 was $0.62 \mathrm{mg} / \mathrm{L}$. The average \\ total-manganese concentration ranged from 0.01 to $33 \mathrm{mg} / \mathrm{L}$. \\ The median of average dissolved-manganese concentration for \\ 119 stations in or near Area 32 was $0.38 \mathrm{mg} / \mathrm{L}$. The average \\ dissolved-manganese concentration ranged from 0.01 to $34 \mathrm{mg} / \mathrm{L}$.
}

Concentrations of total and dissolved manganese were generally higher in the west half of Area 32 than in the east half. This variability may be due to greater surface-mining activity in the west half of the study area than in the east half. The average total- and dissolved-manganese concentrations were grouped into six ranges by percentile, which are presented in figures 4.1.2.6a and $b$. 
EXPLANATION

PERCENTILE $\begin{gathered}\text { MICROGRAMS } \\ \text { PER LITER }\end{gathered}$

$0 \leq 10 \quad<108$

$\triangle \quad 11-25 \quad 108-210$

$\diamond \quad 26-50 \quad 210-616$

$51-75 \quad 616-3034$
$76-90$

$\geq 91$

$3034-9910$

$>9910$
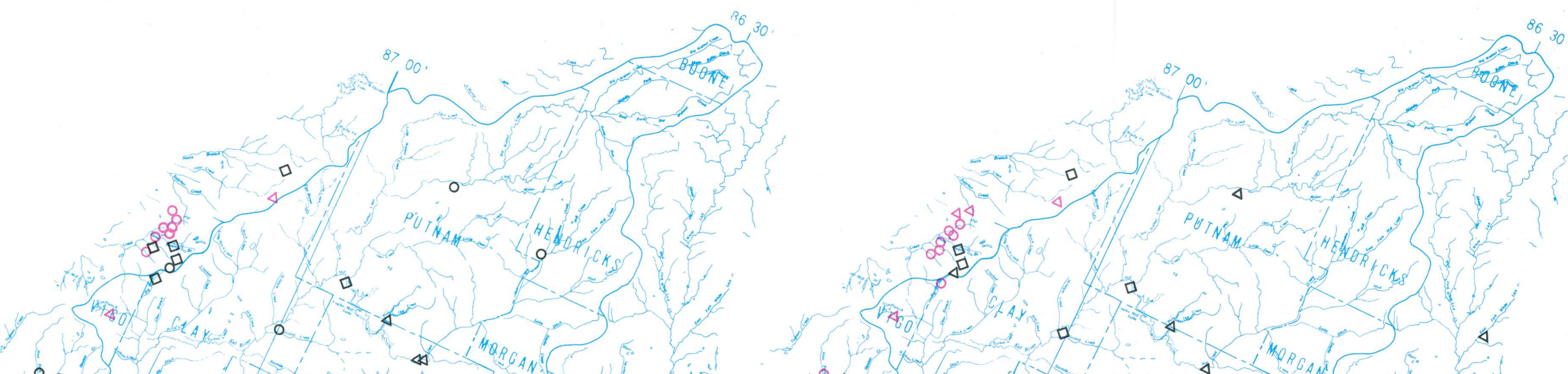

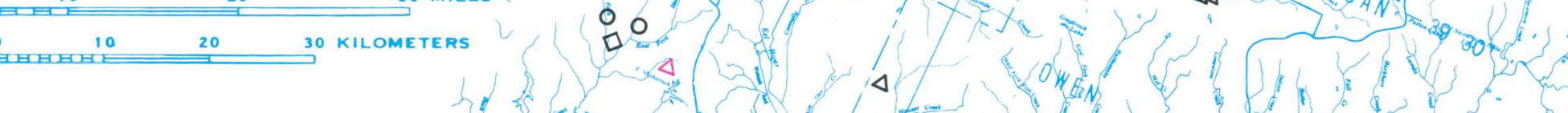

BASE FROM U.S. GEOLOGICAL SURVEY
STATE BASE MAP; 1966

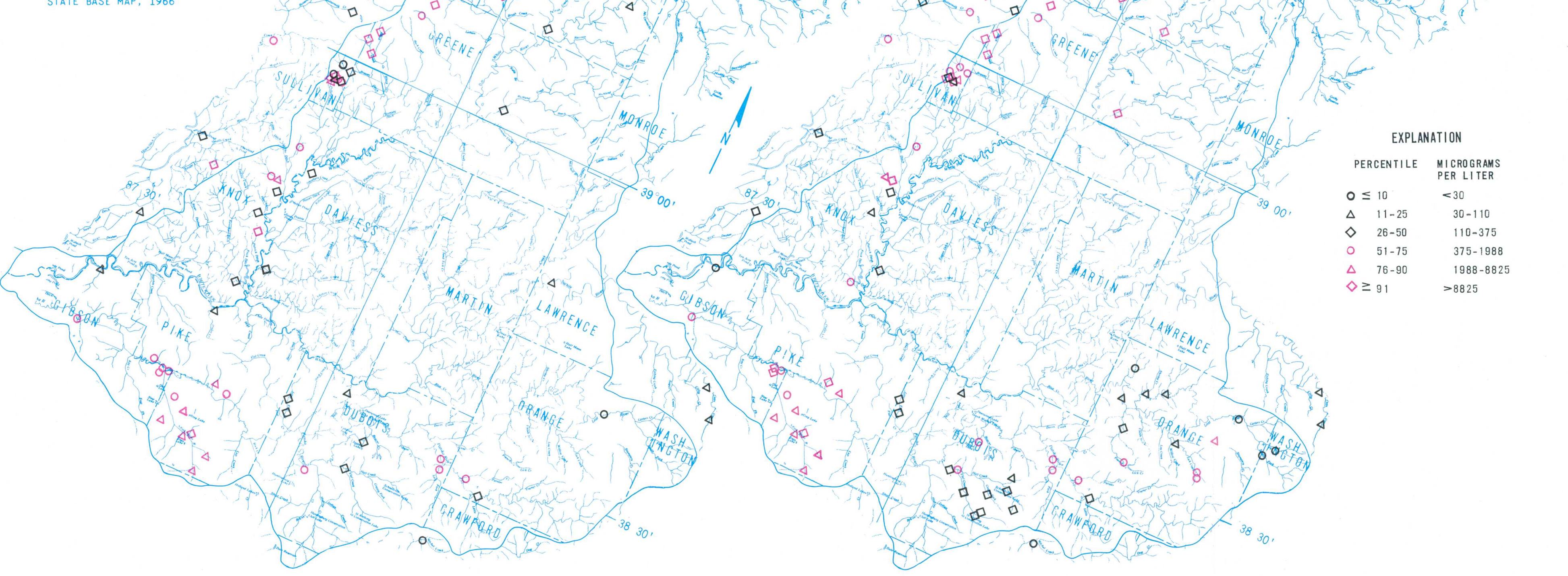




\title{
4.0 WATER QUALITY \\ 4.1 Surface Water \\ 4.1.3 Suspended Sediment
}

\section{SUSPENDED-SEDIMENT DATA FOR SELECTED GAGING STATIONS}

\begin{abstract}
Variation in suspended-sediment concentrations is probably due to geology, physiography, land use, precipitation intensities, and sampling time.
\end{abstract}

Suspended-sediment data available at five sites within Area 32 are listed in table 4.1.3, and their locations are shown on the adjoining map (fig. 4.1.3a). The relation between suspended sediment and discharge at four of the five sites is shown by the curves in the adjoining illustration (fig. 4.1.3b). Although they are not mathematical regressions, the curves show the relation of suspended-sediment concentration to discharge. Suspended-sediment data are available at the Geological Survey office in Indianapolis, Ind.

Table 4.1.3.--Suspended-sediment concentration and discharge information at selected gaging stations

\begin{tabular}{|c|c|c|c|c|c|c|c|c|c|c|c|c|}
\hline \multirow[b]{2}{*}{$\begin{array}{l}\text { Station name } \\
\text { and number }\end{array}$} & \multirow[b]{2}{*}{$\begin{array}{l}\text { Drainage } \\
\text { area } \\
\left(\mathrm{mi}^{2}\right)\end{array}$} & \multirow[b]{2}{*}{$\begin{array}{l}\text { Years } \\
\text { of } \\
\text { record }\end{array}$} & \multirow[b]{2}{*}{$\begin{array}{l}\text { No. of } \\
\text { samples }\end{array}$} & \multicolumn{3}{|c|}{$\begin{array}{c}\text { Discharge } \\
\left(\mathrm{ft}^{3} / \mathrm{s}\right)\end{array}$} & \multicolumn{3}{|c|}{$\begin{array}{l}\text { Suspended } \\
\text { sediment } \\
(\mathrm{mg} / \mathrm{L})\end{array}$} & \multicolumn{3}{|c|}{ Size class of suspended sediment } \\
\hline & & & & $\begin{array}{l}\text { Mini- } \\
\text { mum }\end{array}$ & $\begin{array}{l}\text { Maxi- } \\
\text { mum }\end{array}$ & Median & $\begin{array}{l}\text { Mini- } \\
\text { mum }\end{array}$ & $\begin{array}{l}\text { Maxi- } \\
\text { mum }\end{array}$ & Median & $\begin{array}{l}\text { Sand size } \\
\text { (percent } \\
\text { finer than } \\
2 \mathrm{~mm} \text { ) }\end{array}$ & $\begin{array}{l}\text { Silt size } \\
\text { (percent } \\
\text { finer than } \\
0.062 \mathrm{~mm} \text { ) }\end{array}$ & $\begin{array}{l}\text { Clay size } \\
\text { (percent } \\
\text { finer than } \\
0.004 \mathrm{~mm} \text { ) }\end{array}$ \\
\hline $\begin{array}{l}\text { Big Walnut Creek } \\
\text { nr Reelsville } \\
(03357500)\end{array}$ & 326 & 16 & 58 & 22 & 6,850 & 245 & 5 & 1,420 & 78 & 100 & 81 & 45 \\
\hline $\begin{array}{l}\text { Mill Creek nr } \\
\text { Cataract } \\
(03358000)\end{array}$ & 245 & 11 & 49 & 6.5 & 6,860 & 295 & 6 & 1,240 & 80 & 100. & 83 & 58 \\
\hline $\begin{array}{l}\text { Lost River nr } \\
\text { West Baden } \\
\text { Springs } \\
(03373700)\end{array}$ & 287 & 2 & 14 & 72 & 7,220 & 280 & 14 & 267 & 69 & 100 & 98 & 96 \\
\hline $\begin{array}{l}\text { White River at } \\
\text { Hazleton } \\
(03374100)\end{array}$ & 11,190 & 7 & 57 & 514 & 68,400 & 8,800 & 14 & 513 & 110 & 100 & 84 & 52 \\
\hline $\begin{array}{l}\text { Patoka River at } \\
\text { Princeton } \\
(03376500)\end{array}$ & 822 & 16 & 66 & 3.6 & 11,800 & 290 & 2 & 570 & 40 & --- & -- & -- \\
\hline
\end{tabular}




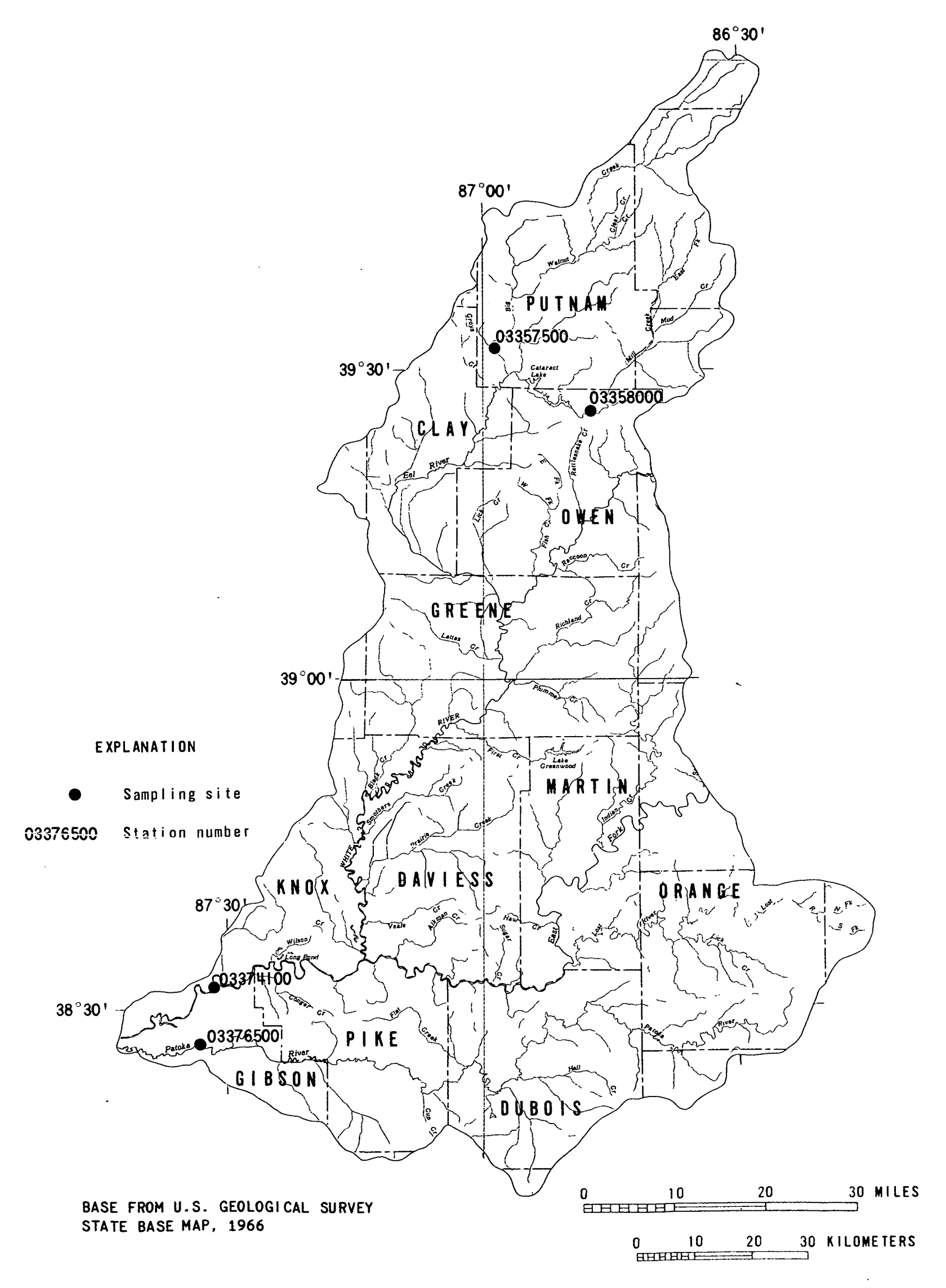

Figure 4,1 3a. -- Suspended-sediment sampling si tes.

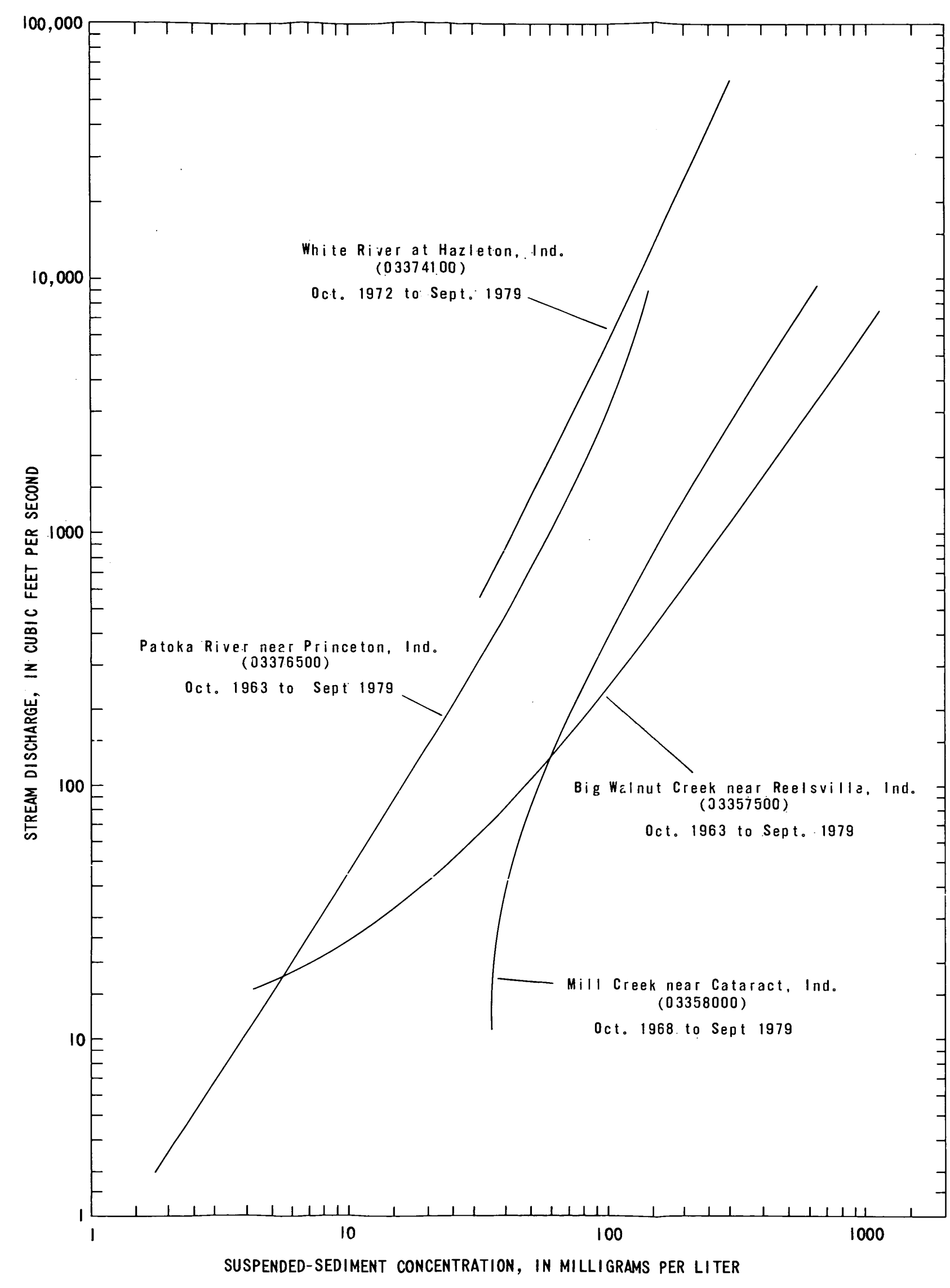

Figure 4.1.3b. -- Relation of suspended-sediment concentration to stream discharge. 


\title{
4.0 WATER QUALITY \\ 4.2 Ground Water
}

\section{GLACIAL AQUIFERS GENERALLY PRODUCE WATER OF BETTER QUALITY THAN BEDROCK AQUIFERS}

\author{
In general, ground-water quality diminishes with depth in Area 32. Sulfate \\ and manganese concentrations are higher in the bedrock aquifers than \\ in the glacial sand and gravel aquifers, but sulfate concentration \\ can be very high locally. Also, dissolved-solids concentration \\ generally decreases with depth. Iron concentration is generally \\ high throughout Area 32.
}

Chemical constituents in ground water are from several sources: (1) the surface materials through which water percolates, (2) minerals in the aquifer, and (3) seepage from surrounding formations ( $\mathrm{Ny}-$ man and Pettijohn, 1971, p. 7). Glacial aquifers and bedrock aquifers near their outcrop areas usually produce water of good quality. Deep bedrock aquifers that are confined by impervious layers usually produce poor-quality and sometimes non-potable water (Harrell, 1935, p. 75-76). According to Nyman and Pettijohn (1971, p. 7), "Wells deeper than $300 \mathrm{ft}$ (in the Wabash River basin) generally yield mineralized or saline water."

The ground-water-quality parameters considered in this section are $\mathrm{pH}$ and concentrations of dissolved solids, total iron, total manganese, and sulfate. For convenience, the concentrations presented are compared to the National Secondary Drinking Water Standards of the U.S. Environmental Protection Agency (1979) drinking water standards as a point of reference.

A pH of less than 6.5 can contribute to the corrosive potential of the water, and values greater than 8.5 can give the water a bitter taste or cause encrustation of pipes (U.S. Environmental Protection Agency, 1979, p. 42201). The median pH's in the glacial and bedrock aquifers are 7.2 and 7.6, respectively (fig. 4.2a). Dissolved-solids concentrations greater than $500 \mathrm{mg} / \mathrm{L}$ may cause excessive hardness, mineral deposition, corrosion, and adverse taste (U.S. Environmental Protection Agency, 1979, p. 42201). The median dissolved-solids concentration in glacial (sand and gravel) aquifers is $316 \mathrm{mg} / \mathrm{L}$ and in bedrock aquifers is $391 \mathrm{mg} / \mathrm{L}$ (fig. 4.2a). However, the dissolved-solids concentration generally increases with depth as shown in figure $4.2 \mathrm{~b}$. Iron and manganese concentrations greater than 0.3 and 0.05 $\mathrm{mg} / \mathrm{L}$, respectively, cause taste and staining problems (National Academy of Sciences and the National Academy of Engineering 1972 [1974], p. 69 and 71). The median total-iron concentrations of water in bedrock and glacial aquifers are $0.5 \mathrm{mg} / \mathrm{L}$, and the median total-manganese concentration of water in the bedrock is $0.02 \mathrm{mg} / \mathrm{L}$. Sulfate concentrations greater than $250 \mathrm{mg} / \mathrm{L}$ cause adverse taste and laxative effects, but consumers can adjust to these concentrations (U.S. Environmental Protection Agency, 1979). The median-sulfate concentration in glacial aquifers is $22 \mathrm{mg} / \mathrm{L}$ and in bedrock aquifers is 20 $\mathrm{mg} / \mathrm{L}$.

The adjacent bar graphs (fig. 4.2a) show the medians and ranges of concentrations for constituents and properties of the water from glacial and combined bedrock aquifers. Although the data sources are not equally distributed areally, the generalized graphs are representative of the water-quality range in the study area. Additional water-quality data from wells in the study area have been processed into the National Water Data Storage and Retrieval System by latitude and longitude and are available at the Indiana District Office of the Geological Survey, Indianapolis, Ind. However, for most samples, the aquifer has not been identified, and the information is of limited use. 


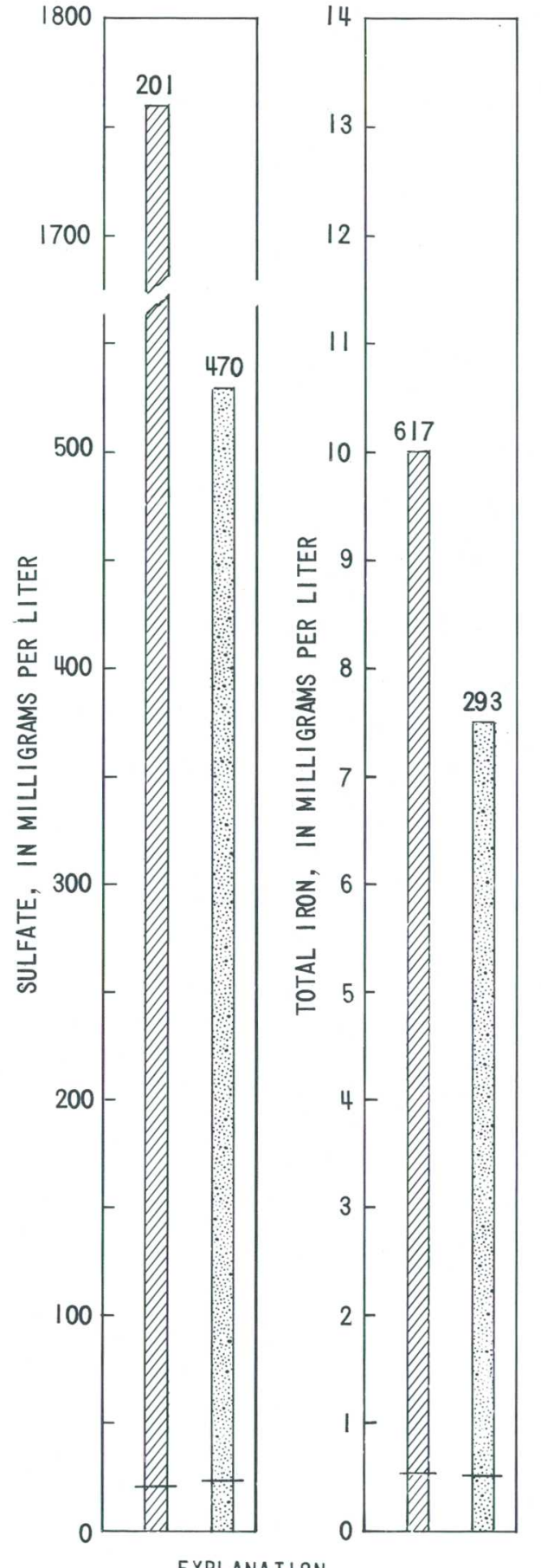

explanation

T.: Sand and grav

PIIIA Bedrock

- Median

201 Numbers of samples

Figure 4.2a. -- Median concentrations and ranges in concentration of selected ground-water-quality parameters

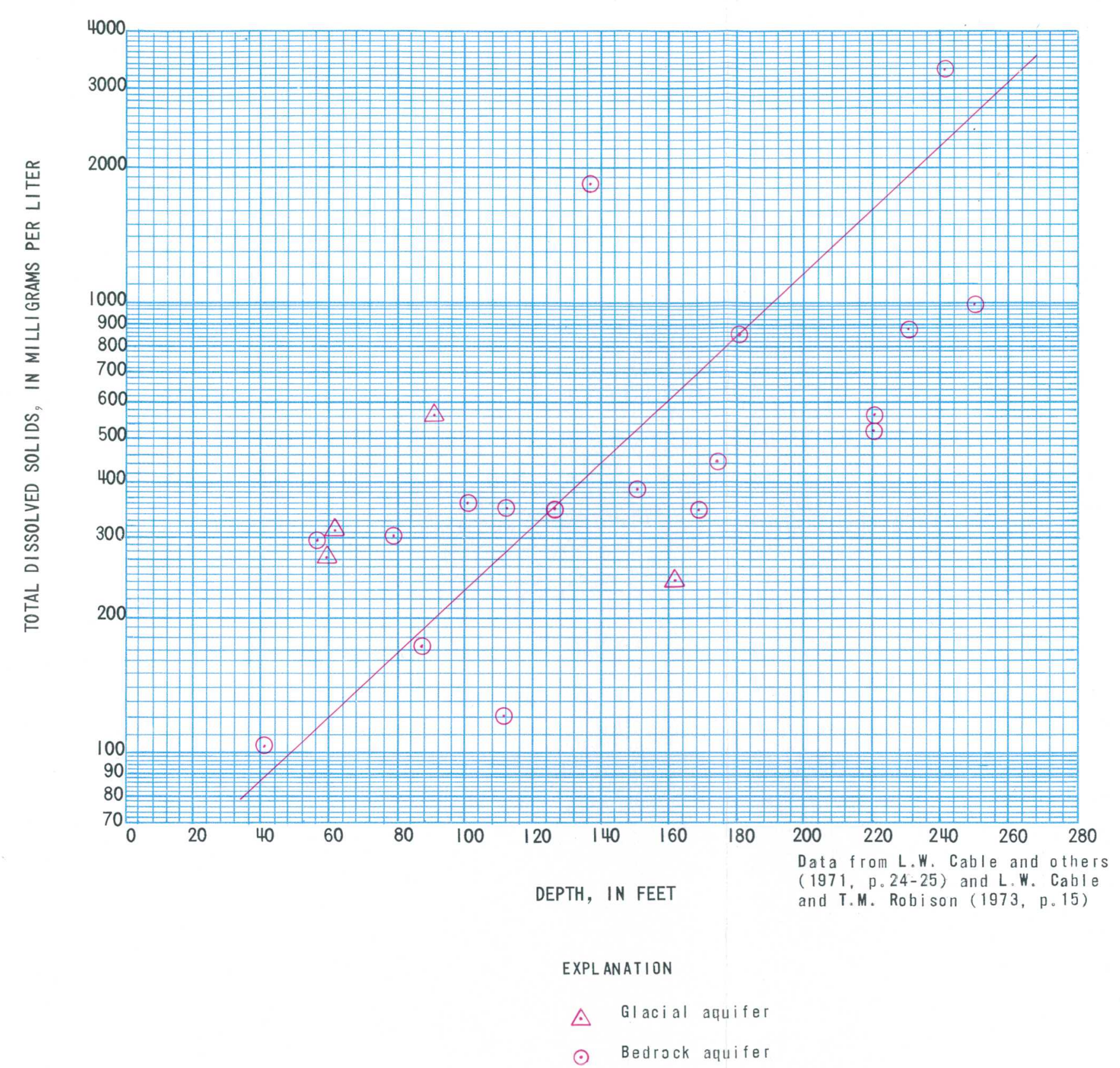

Figure 4.2b. -- Relation of dissolved-solids concentration to depth in Clay and Greene Counties, Ind 
. 


\title{
5.0 WATER-DATA SOURCES \\ 5.1 Introduction
}

\section{NAWDEX, WATSTORE, AND OWDC HELP USERS OBTAIN WATER DATA}

\author{
Water data in coal areas are collected by many organizations \\ in response to a wide variety of needs.
}

Three facilities within the Geological Survey help to identify and improve access to the vast amount of water data:

(1) The National Water-Data Exchange (NAWDEX), which indexes the water data available from more than 400 organizations and serves as a central focal point for determining what water data are available.

(2) The National Water-Data Storage and RetrievaL System (WATSTORE), which serves as the central repository of water data collected by the Geological Survey and which contains large volumes of data on the quantity and the quality of both surface water and ground water.

(3) The Office of Water Data Coordination (OWDC), which coordinates Federal water-data acquisition activities and maintains a "Catalog of Information on Water Data." Special indexes to the catalog, identifying water-data facilities in coal provinces of the United States, are being printed and made available to the public.

More detailed explanations of items 1, 2, and 3 are given in sections 5.2, 5.3, and 5.4. 


\author{
5.0 WATER-DATA SOURCES \\ 5.2 National Water-Data Exchange--NAWDEX
}

\title{
NAWDEX SIMPLIFIES ACCESS TO WATER DATA
}

\author{
The National Water-Data Exchange (NAWDEX) is a nationwide \\ facility managed by the Geological Survey to assist users of \\ water data or water-related data in identifying, locating, \\ and acquiring data.
}

NAWDEX is a national confederation of wateroriented organizations working together to make their data readily accessible and to facilitate an efficient exchange of water data.

Services are available through a Program Office at the Geological Survey National Center in Reston, Va., and a nationwide network of Assistance Centers in 45 states and Puerto Rico, which provide local and convenient access to NAWDEX facilities. A directory that provides names of organizations and persons to contact, as well as addresses, telephone numbers, and office hours for each of these organizations, is available on request (Edwards, 1979).

NAWDEX can assist any organization or individual in identifying and locating water data. To accomplish this service, NAWDEX maintains a computerized Master Water-Data Index, which identifies sites for which water data are available, the type of data available for each site, and the organization retaining the data. NAWDEX also maintains a Water-Data Sources Directory identifying organizations from which data may be obtained. In addition, NAWDEX has direct access to some large water-data bases of its members and has reciprocal agreements for the exchange of services with others.

Charges for NAWDEX services are assessed at the option of the organization providing the requested data or data service. Search assistance services are provided free by NAWDEX to the greatest extent possible. Charges are assessed, however, for requests requiring computer time, extensive personnel time, duplicating services, or other costs to NAWDEX in providing services. Charges assessed by NAWDEX Assistance Centers will not exceed the direct costs incurred in responding to the data request. Estimates of cost are provided by NAWDEX on request and where costs are anticipated to be substantial.

For additional information on the NAWDEX program or its services, contact:

Program Office

National Water Data Exchange (NAWDEX)

U.S. Geological Survey

421 National Center

12201 Sunrise Valley Drive

Reston, VA 22092

Telephone: (703)860-6031

FTS 928-6031

Hours: 7:45 - 4:15 eastern time

or

\section{NAWDEX ASSISTANCE CENTER} Indiana

U.S. Geological Survey

Water Resources Division 1819 North Meridian St. Indianapolis, IN 46202

Telephone: (317) 269-7101

FTS 331-7101

Hours: 7:30 - 4:00 eastern time 


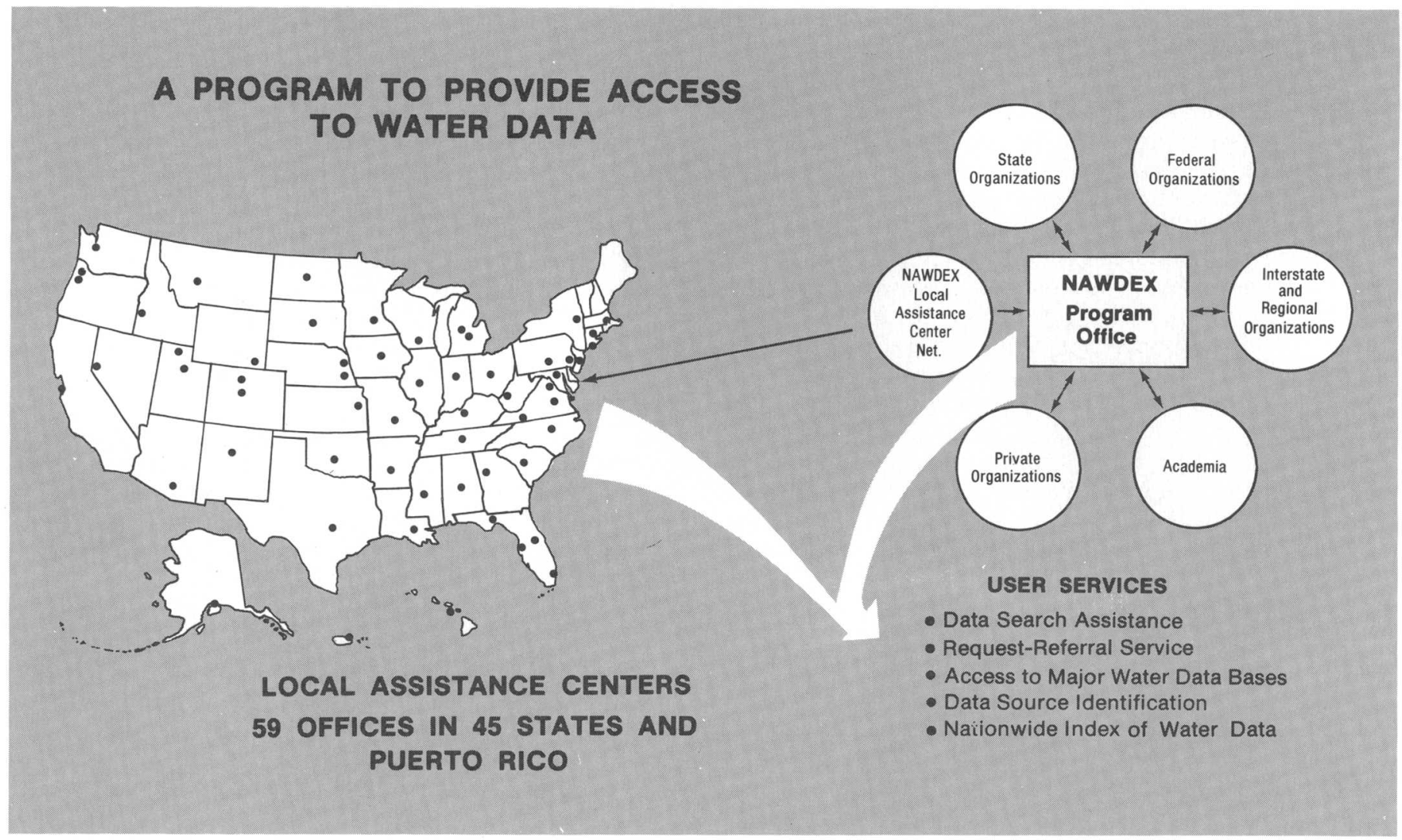

Figure 5.2-1 Access to water data
MASTER WATER DATA INDEX

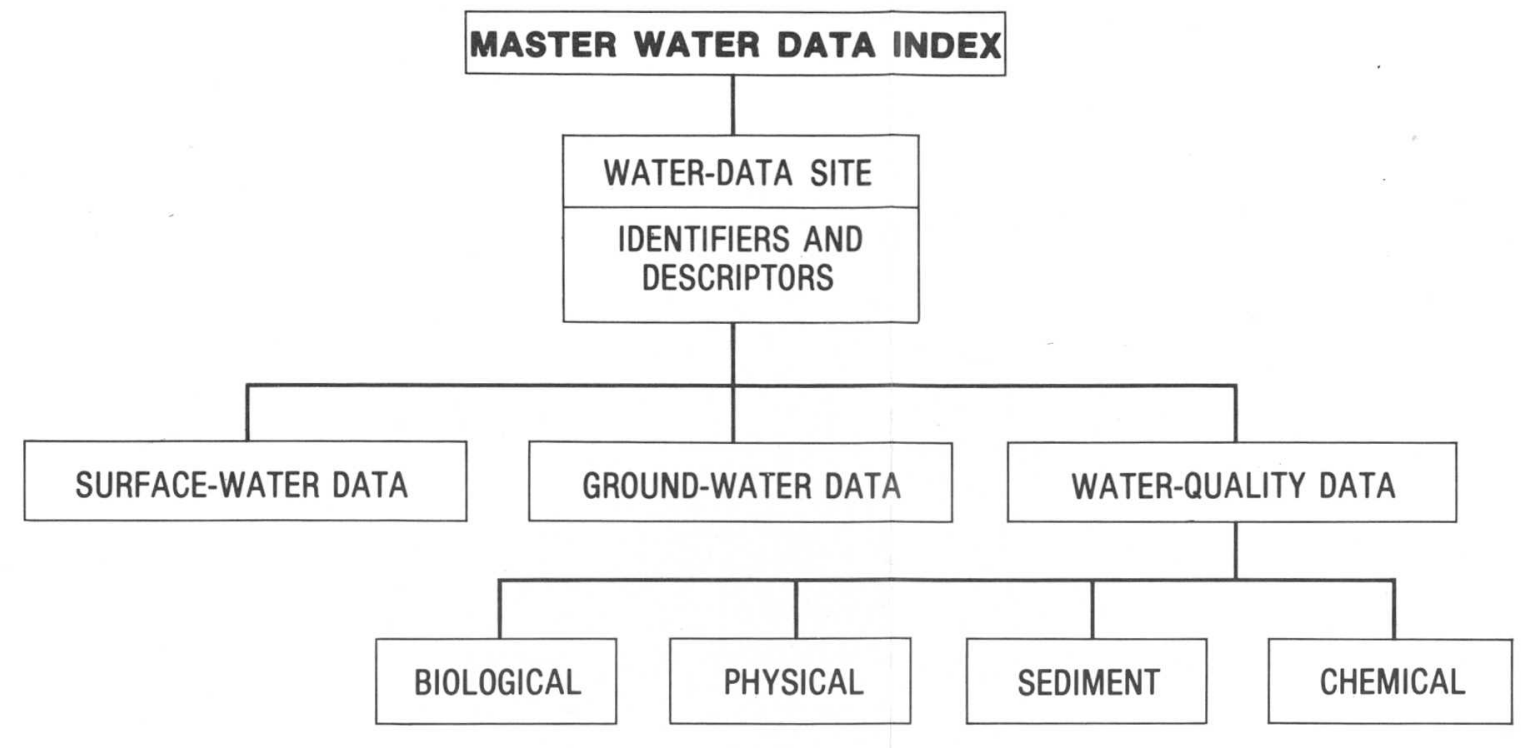

Figure 5.2-2 Master water-data index

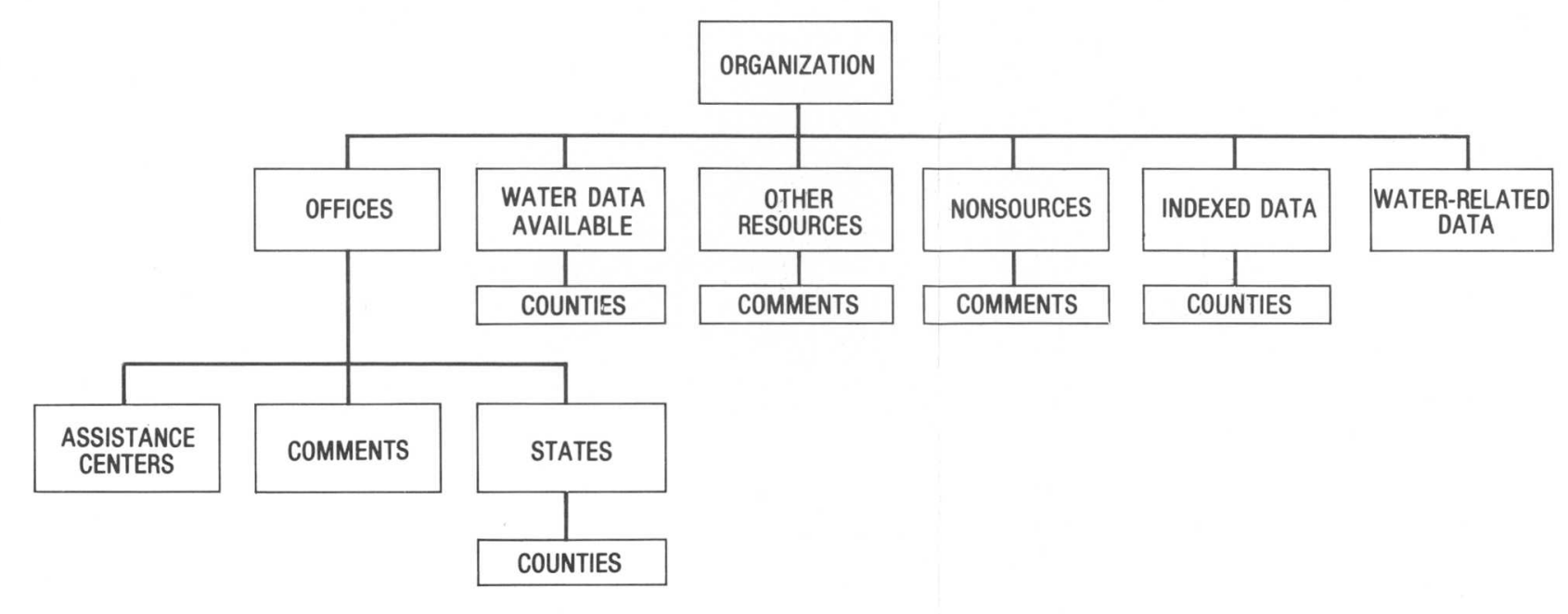

Figure 5.2-3 Water-data sources directory 


\title{
5.0 WATER-DATA SOURCES \\ 5.3 WATSTORE
}

\section{WATSTORE AUTOMATED DATA SYSTEM}

\author{
The National Water-Data Storage and Retrieval System (WATSTORE) of the \\ Geological Survey provides computerized procedures and \\ and techniques for processing water data.
}

The National Water-Data Storage and Retrieval System (WATSTORE) was established in November 1971 to computerize the water-data system of the Geological Survey and to provide for more effective and efficient management of its data-releasing activities. The system is operated and maintained on the central computer facilities of the Survey at its $\mathrm{Na}$ tional Center in Reston, Va. Data may be obtained from WATSTORE through 46 district offices of the Water Resources Division. General inquiries about WATSTORE may be directed to: Chief Hydrologist

U.S. Geological Survey 437 National Center Reston, VA 22092

or

U.S. Geological Survey

Water Resources Division 1819 North Meridian St. Indianapolis, IN 46202

The Geological Survey currently (1980) collects data at approximately 16,000 stream-gaging stations, 1,000 lakes and reservoirs, 5,200 surface-water-quality stations, 1,020 sediment stations, 30,000 observation wells, and 12,500 ground-water quality wells. Each year many water-data collection sites are added, and others are discontinued. Thus, large amounts of diversified data, both current and historical, are amassed by the data-collection activities of the Survey.

The WATSTORE system consists of several files in which data are grouped and are stored by common characteristics and data-collection frequencies. The system is designed to allow for the addition of data files as needed. Files are maintained for the storage of (1) surface-water, quality-of-water, and groundwater data measured on a daily or continuous basis; (2) annual peak values for streamflow stations; (3) chemical analyses for surface- and ground-water sites; (4) water parameters measured more frequently than daily; and (5) geologic and inventory data for ground-water sites. In addition, an index file of sites for which data are stored in the system is also maintained. A brief description of each file follows:

Station-Header File: All sites for which data are stored in the DailyValues, Peak-Flow, Water-Quality, and Unit Values files of WATSTORE are indexed in this file. It contains information pertinent to the identification, location, and physical description of nearly 220,000 sites.

Daily-Values File: All water-data parameters measured or observed, either on a daily or on a continuous basis, and numerically reduced to daily values are stored in this file. Instantaneous measurements at fixed-time intervals, daily mean values, and statistics such as daily maximum and minimum values also may be stored. The file currently contains over $\mathbf{2 0 0}$ million daily measurements including data on streamflow, river stage, reservoir content, water temperature, specific conductance, sediment concentration, sediment discharge, and ground-water level.

Peak-Flow File: Annual maximum (peak) streamflow (discharge) and gage height (stage) data at surface-water sites compose this file, which currently contains more than 400,000 peak measurements.

Water-Quality File: Analyses of more than 1.4 million water samples in this file indicate the chemical, physical, biological, and radiochemical characteristics of both surface water and ground water. These analyses include data for 185 constituents and properties.

Unit-Values File: Water parameters measured more frequently than daily are stored in this file. Rainfall, stream-discharge, and water-temperature data are examples of the types of data stored in the Unit-Values File.

Ground-Water Site-Inventory File: This file is 
maintained with WATSTORE independent of the preceding files, but it is cross referenced to the
Water-Quality File and the Daily-Values File. file contains inventory data on wells and springs. Examples of data are site location, site identification, geohydrologic characteristics, well-construction history, and one-time field measurements of water temperate ele 700,000 sites.

All data files of the WATSTORE system are maintained and managed on the central compurer facilities of the Geological Survey at its Nationa Center. However, data may be entered into or $\mathrm{re}$ are part of a nationwide telecommunication network.

Remote Job-Entry Sites: Almost all district of fices of the Water Resources Division are equipped with high-speed computer terminals for remote access to the WATSTORE system. These terminals atlow each site to put data into or retrieve data fro to overnight, depending on the priority of the re quest. The number of remote job-entry sites is increased as the need arises.

Digital-Transmission Sites: Digital recorders are used at many field locations to record values for water temperature, turbidity, wind direction, and chioride concentration. Data are recorded on 16-channel paper tape and are transmitted over telephone lines to the receiver at Reston, Va. The data are recorded on magnetic tape for use on the central tion platforms indicates their feasibility for collecting real-time hydrologic data on a national scale. Battery-operated radios are used as the communication link to the satellite. About 200 data-relay stations are being operated currently (1980).

Central-Laboratory System: The two waterin Denver, Colo, and Atlanta, $\mathrm{Ga}$, ansye more than 150,000 water samples per year. These laboratories are equipped to determine concentrations of dissolved constituents ranging from simple inorganic compounds, such as pesticides, and to measure vari- ous properties of water. After verification by laboratory personnel, results of each analysis are transmitted by a computer terminal to the central computer WATSTORE.

Water data are used in many ways in the management, development, and monitoring of water reand retrieval capabilities, WATSTORE can provide a variety of useful products ranging from simple data tables to complex statistical analyses. A minimal fee, plus the actual computer cost to produce a desired product, is charged to the requester

Computer-Printed Tables: Users most often request data from WATSTORE in the form of tables printed by the computer. These tables may contain lists of data or condensed indexes that indicate the availability of data stored in the files. A variety of data.

Computer-Printed Graphs: Computer-printed graphs for the rapid analysis or display of data are another capability of WATSTORE. Computer programs are available to produce bar graphs (histograms), line graphs, frequency distribution curves, X-Y point plots, site-location map plots, and

Statistical Analyses: WATSTORE interface (SÁ) to provide exiensive of variance, transformations, and correlations.

Digital Plotting: WATSTORE also uses software systems that prepare data for digital plotting on computer site. Hydrographs, frequency-distribution curves, $\mathrm{X}$-Y points, contours, and three-dimensional illustrations can be plotted.

Data in Machine-Readable Form: Data stored in form for use on other computers or for use as inpu to user-written computer programs. These data are available in the standard storage format of the WATSTORE system or in the form of punched cards or card images on magnetic tape.

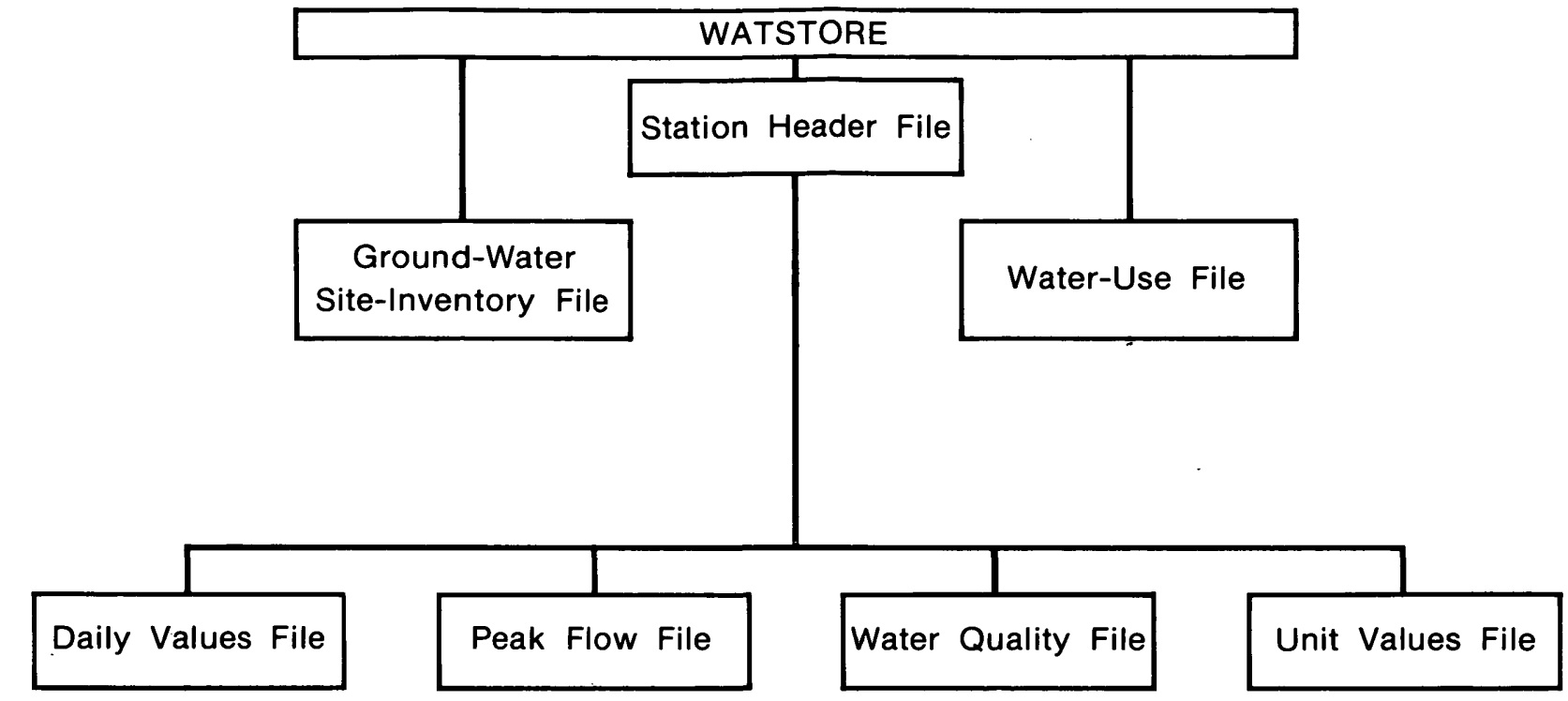

Figure 5.3-1 Files of stored data. 


\author{
5.0 WATER-DATA SOURCES \\ 5.4 Index to Water-Data Activities in Coal Provinces
}

\title{
WATER DATA INDEXED FOR COAL PROVINCES
}

\author{
A special index, "Index to Water-Data Activities in Coal \\ Provinces of the United States," has been published by the \\ Geological Survey Office of Water Data Coordination (OWDC).
}

The "Index to Water-Data Activities in Coal Provinces of the United States" was prepared to provide information on the availability of water-resources data in the major coal provinces of the United States for people developing, managing, and regulating the coal resources of the Nation. It is derived from the "Catalog of Information on Water Data," a computerized information file about waterdata acquisition in the United States and some other countries. The index does not contain the actual data; rather, it provides information that will enable the user to determine if needed data are available. The index consists of five volumes: volume I, Eastern Coal province; volume II, Interior Coal province; volume III, Northern Great Plains and Rocky Mountain Coal provinces; volume IV, Gulf Coast Coal province; and volume V, Pacific Coast and Alaska Coal provinces. These volumes aid the user in obtaining data for evaluating the effects of coal mining on water resources and in developing plans for meeting additional water-data needs.

Each volume of the special index consists of four parts: Part A, Stream-flow and Stage Stations; Part B, Quality of Surface-Water Stations; Part C, Quality of Ground-Water Stations; and Part D, Areal Investigations and Miscellaneous Activities. Information given for each activity in Parts A-C includes (1) identification and location of the station, (2) major types of data collected, (3) frequency of data collection, (4) form in which the data are stored, and (5) agency or organization reporting the activity. Part D summarizes areal hydrologic investigations and water-data activities not included in the other parts of the index. The agencies that submitted the information, agency codes, and the number of activities reported by type are shown in a table.

Assistance in obtaining information from the Catalog file or water data is available through the National Water Data Exchange (NAWDEX).

Further information on the index volumes and their availability may be obtained from:

$$
\begin{aligned}
& \text { U.S. Geological Survey } \\
& \text { Water Resources Division } \\
& 1819 \text { North Meridian St. } \\
& \text { Indianapolis, IN } 46202
\end{aligned}
$$$$
\text { Telephone: (317) 269-7101) }
$$$$
\text { FTS 331-7101 }
$$

or

Office of Surface Mining

U.S. Department of the Interior 46 East Ohio Street

Indianapolis, IN 46202

Telephone: (317) 269-2600

FTS 331-2636 or

FTS 331-2600 


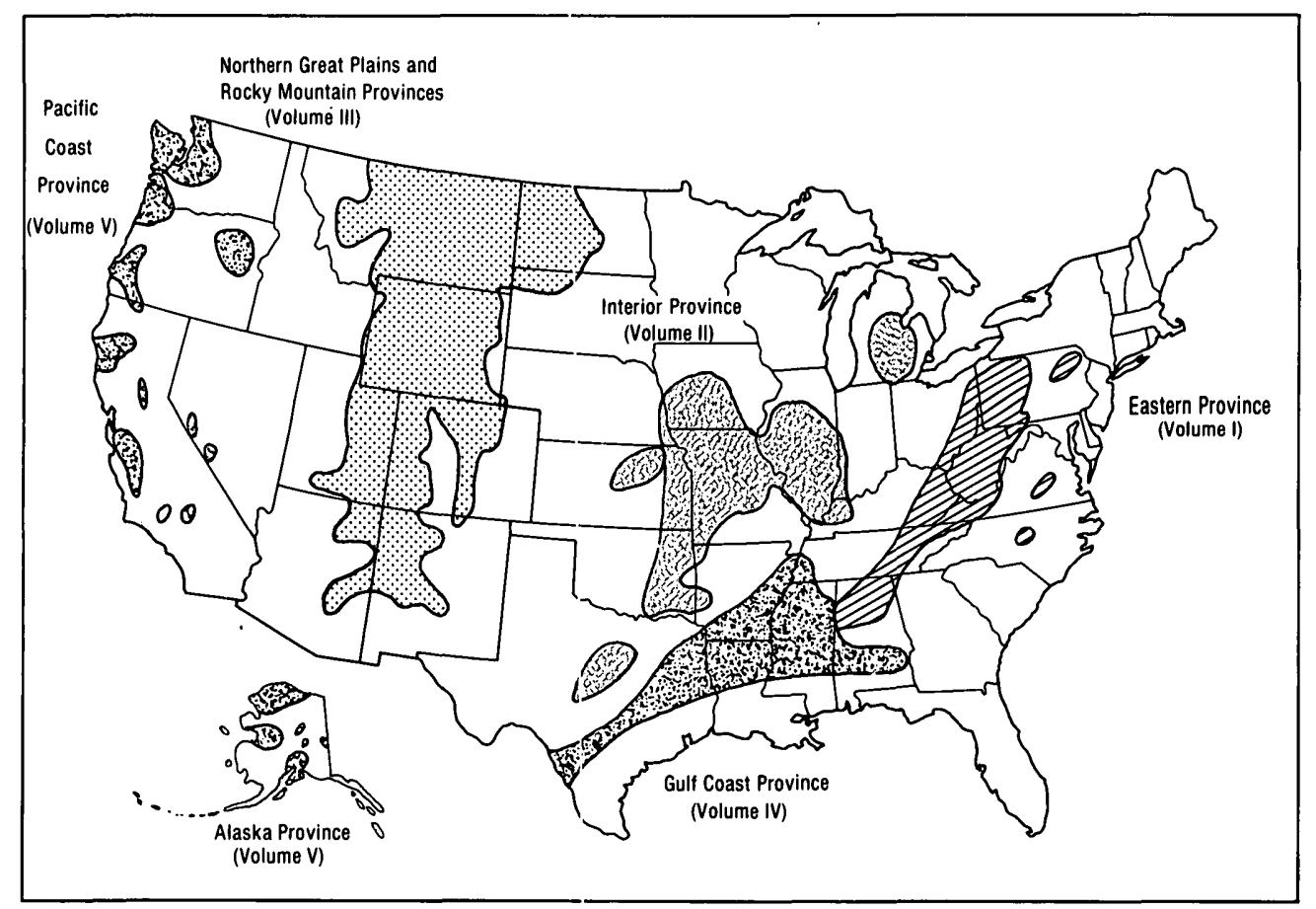

Figure 5.4-1 Index volumes and related provinces 


\subsection{REFERENCES}

6.1 References Cited

\section{LITERATURE AND DATA SOURCES CITED WITHIN THE STUDY-AREA 32 REPORT}

American Public Health Association and others, 1976, Standard methods for the examination of water and wastewater (14th ed.): New York, American Public Health Association and others, $1,193 \mathrm{p}$.

Barr, A. J., and others, 1979, SAS user's guide (1979 ed.): Raleigh, N.C., SAS Institute Inc., 494 p.

Cable, L. W., Watkins, F. A., and Robison, T. M., 1971, Hydrogeology of the principal aquifers in Vigo and Clay Counties, Indiana: Indiana Department of Natural Resources, Division of Water, Bulletin no. 34, 34 p.

Cable, L. W., and Robison, T. M., 1973, Hydrogeology of the principal aquifers in Sullivan and Greene Counties, Indiana: Indiana Department of Natural Resources, Division of Water, Bulletin no. 35, $26 \mathrm{p}$.

Carter, R. P., and others, 1974, Surface mined land in the midwest: Argonne National Laboratory, Energy and Environmental Systems Division, ANL/ES-43, $691 \mathrm{p}$.

Clark, G. D., ed., 1980, The Indiana water resource, availability, uses, and needs: Indiana Department of Natural Resources, $508 \mathrm{p}$.

Corbett, D. M., 1965, Water supplied by coal surface mines, Pike County, Indiana: Bloomington, Ind., Indiana University Water Resources Research Center Report of Investigations no. 1, 67 p.

Davis, L. G., 1974, Floods in Indiana: Technical manual for estimating their magnitude and frequency: U.S. Geological Survey Circular 710, 40 p.

Dyer, K.L., and Curtis, W. R., 1977, Effects of strip-mining on water quality in small streams in eastern Kentucky: U.S. Forest Service Research Paper NC-372, $13 \mathrm{p}$.

Edwards, M. D., 1979, Directory of assistance centers of the National Data Exchange (NAWDEX): U.S. Geological Survey Open-File Report 79-423, $10 \mathrm{p}$.

Gold, R. L., 1980, Flood magnitude and frequency of streams in Indiana: Preliminary estimating equations: U.S. Geological Survey Open-File Report 80-759, $44 \mathrm{p}$.

Gray, H. H. and Powell, R. L., 1965, Geomorphology and ground-water hydrology of the Mitchell Plain and Crawford Upland in southern Indiana:
Indiana Department of Natural Resources, Geological Survey, Field Conference Guidebook 11, $26 \mathrm{p}$.

Gray, H. H., Wayne, W. J., and Wier, C. E., 1970, Regional geologic map no. 3, Vincennes quadrangle: Indiana Department of Natural Resources, Geological Survey, scale 1:250,000.

Harrell, Marshall, 1935, Ground water in Indiana: Indianapolis, Ind., Department of Public Works, Conservation Department, Division of Geology, Pub. no. 133, 504 p.

Hem, J. D., 1970, Study and interpretation of the chemical characteristics of natural water $(2 \mathrm{~d}$ ed.): U.S. Geological Survey Water-Supply Paper $1473,363 \mathrm{p}$.

Hoehn, R. C., and Sizemore, D. R., 1977, Acid mine drainage (AMD) and its impact on a small Virginia stream: Water Resources Bulletin, v. 13, no. 1, p. 153-160.

Hoggatt, R. E., 1975, Drainage areas of Indiana streams: Indiana Department of Natural Resources, Division of Water, $231 \mathrm{p}$.

Hutchison, N. E., Compile, 1975, WATSTORE user's guide, v. 1: U.S. Geological Survey Open-File Report 75-426, 708 p.

Indiana Bureau of Mines and Mining, 1972 through 1979, Annual report of the Bureau of Mines and Mining, State of Indiana: Terre Haute, Indiana Bureau of Mines and Mining.

Indiana Department of Natural Resources, 1974, Rainfall frequency curves for Indiana: Indiana Department of Natural Resources, Division of Water, $100 \mathrm{p}$.

1979, Coordinated discharges of selected streams in Indiana: Indiana Department of Natural Resources, Division of Water, $118 \mathrm{p}$. 1980 , Permanent surface mining control and reclamation program proposed: Indiana Department of Natural Resources, $520 \mathrm{p}$.

Indiana State Board of Health, Stream Pollution Control Board, 1980, Indiana State 208 waterquality management planning maps, regions 4 , 10, 13a, 136, and 15: Indiana State Board of Health, Stream Pollution Control Board.

King, D. L., and others, 1974, Acid strip mine lake recovery: Journal Water Pollution Control Federation, v. 46, no. 10, p. 2301-2315.

Letterman, R. D., and Mitsch, W. J., 1978, Impacts 
of mine drainage on a mountain stream in Pennsylvania: Environmental Protection, v. 17, p. 53-73.

National Academy of Sciences and the National Academy of Engineering, 1972 [1974], Waterquality criteria, 1972: U.S. Government Printing Office, $594 \mathrm{p}$.

Nyman, D. J., and Pettijohn, R. A., 1971, Wabash river basin comprehensive study, Appendix G, Ground water: Louisville, Ky., U.S. Army, Corps of Engineers, 100 p.

Office of Surface Mining, 19\%9, Surface coal mining and reclamation operations: Permanent regulatory programs: Federal Register, v. 44, no. 50, book 3, p. 15311-15463.

Patton, J. B., 1956, Geologic map of Indiana: Indiana Geological Survey, scale 1:1,000,000.

Powell, R. L., 1972, Coal strip-mined land in Indiana: Indiana Department of Natural Resources, Geological Survey Special Report 6, 18 p.

1976, Map of southwestern Indiana showing areas strip mined for coal: Indiana Department of Natural Resources, Geological Survey miscellaneous map no. 15.

1977, Map of southwestern Indiana showing locations of active coal mines: Indiana Department of Natural Resources, Geological Survey miscellaneous map no. 7 .

Schaal, L. A., 1959, Climates of the states--Indiana: U.S. Department of Commerce, Weather Bureau, Climatography of the United States no. 60-12, $16 \mathrm{p}$.

Schaal, L. A., 1966, Climate, in Lindsey, A. A., ed., Natural features of Indiana: Indiana Academy of Science and Indiana State Library, p. 156-170.

Schneider, A. F., 1966, Physiography, in Lindsey, A. A., ed., National features of Indiana: Indiana Academy of Science and Indiana State Library, p. 40-56.

Shaver, R. H. and others, 1970, Compendium of rock-unit stratigraphy in Indiana: Indiana Department of Natural Resources, Geological Survey Bulletin 43, 229 .

Steen, W. J. and others, 1977, Water resources of Boone County, Indiana: Indiana Department of Natural Resources, map scale 1 inch $=1$ mile, 1 sheet.

Sunderman, J. A., 1968, Geology and mineral resources of Washington County, Indiana: Indiana Department of Natural Resources, Geological Survey Bulletin 39, 90 p.

Tracey, J. R., 1974, Managing-editing a STOP proposal: The technical editor as a bookbuilder, in Proceedings of $21 \mathrm{st}$ International Technical Communications Conference, May 15-18, 1974, St. Louis, Mo., p. 157-164.

U.S. Environmental Protection Agency, 1979, National secondary drinking water regulations:
Federal Register, v. 44, no. 140, July 19, 1979, p. 42195-42202.

U.S. Geological Survey, 1976, Water resources data for Indiana, Water year 1975: U.S. Geological Survey Water-Data Report IN-75-1, 355 p. 1977, Water resources data for Indiana, water year 1976: U.S. Geological Survey Water-Data Report IN-76-1, 363 p. 1978, Water resources data for Indiana, water year 1977: U.S. Geological Survey Water-Data Report IN-77-1, 357 p. 1979, Water resources data for Indiana, water year 1978: U.S. Geological Survey Water-Data Report IN-78-1, 383 p.

U.S. Soil Conservation Service, 1975, Urban hydrology for small watersheds: U.S. Soil Conservation Service, Engineering Division, Technical Release no. 55,91 p.

1977a, Prime farmland of Indiana: U.S. Department of Agriculture, Soil Conservation Service in cooperation with Purdue University Agriculture Experiment Station, Prime Farmland Map, scale 1:500,000.

1977b, Soil associations of Indiana: U.S. Soil Conservation Service in cooperation with Purdue University, Agricultural Experiment Station, Soil Associations Map, Scale: $1: 500,000$.

Wangsness, D. J., and others, Hydrologic assessment of Area 33, eastern region, Interior Coal Province, southwestern Indiana and northern Kentucky: U.S. Geological Survey WaterResources Investigations Open-file report 81-423 (in press).

Watkins, F. A., Jr., and Jordan, D. G., 1961, Ground-water resources of west-central Indiana, preliminary report: Greene County: Indiana Department of Conservation, Division of Water Bulletin no. 11, $255 \mathrm{p}$.

1962, Ground-water resources of west-central Indiana, preliminary report: Clay County: Indiana Department of Conservation, Division of Water Bulletin no. 16, 309 p.

1963, Ground-water resources of west-central Indiana, preliminary report: Owen County: Indiana Department of Natural Resources, Division of Water, Bulletin no. 18, 99 p. 1964, Ground-water resources of west-central Indiana, preliminary report: Putnam County: Indiana Department of Natural Resources, Division of Water, Bulletin no. 21, 83 p.

Wayne, W. J., 1958, Glacial geology of Indiana: Indiana Department of Conservation, Geological Survey, Atlas of Mineral Resources of Indiana, Map. no. 10, scale 1:1,000,000.

1966, Ice and land, A review of the Tertiary and Pleistocene history of Indiana, in Lindsey, A. A., ed., Natural features of Indiana: 
Indiana Academy of Science and Indiana State Library, p. 21-39.

Wier, C. E., 1973, Coal resources of Indiana: Indiana Department of Natural Resources, Geological Survey Bulletin no. 42-I, 40 p.
Wier, C. E., and Gray, H. H., 1961, Regional geologic map, Indianapolis sheet: Indiana Geological Survey, Scale 1:250,000. 


\subsection{REFERENCES \\ 6.2 Additional Reading}

\section{LITERATURE ANI DATA SOURCES AVAILABLE FOR ADDITIONAL READING}

Brown, E. A., 1949, Ground water resources of Boone County, Indiana: Indiana Department of Conservation, Division of Water Resources, Bulletin no. 4, $152 \mathrm{p}$.

Corbett, D. M., 1969, Acid mine drainage problem of the Patoka River Watershed, southwestern Indiana: Bloomington, Ind., Indiana University Water Resources Research Center, Report of Investigations no. $4,173 \mathrm{p}$.

Fidlar, M. M., 1948 Physiography of the lower Wabash valley: Indiana Department of Conservation, Geological Survey, Bulletin no. 2, $112 \mathrm{p}$.

Friedman, S. A., 1954, Distribution, structure, and mined areas of coals in Gibson County, Indiana: Indiana Department of Conservation, Geological Survey, Preliminary Coal Map 4, scale 1 inch $=2$ miles.

Galloway, H. M., 1978, Indiana soil series and their properties: Purdue University Cooperative Extension Service Agricultural Experiment Station in cooperation with the Soil Conservation Service, $A V-212,13 \mathrm{p}$.

Galloway, H. M., Yahner, J. E., Srinivasan, G., and Franzmeier, D. P., 1977, User's guide to the general soil maps and interpretive data for counties of Indiana: Purdue University cooperative Extension Service Agricultural Experiment Station in cooperation with the Soil Conservation Service, Supplement to AY-50 Series, $27 \mathrm{p}$.

Gray, H. H., 1963, Geology of the upper Patoka drainage basin: Indiana Department of Conservation, Geological Survey, Special Report no. 2, $23 \mathrm{p}$.

Gray, H. H., 1971, Glacial lake deposits in southern Indiana--engineering problems and land use: Indiana Department of Natural Resources, Geological Survey, Report of Progress no. 30, 15 p.

Gray, H. H. and others, 1979, Regional geologic map no. 1, Indianapolis sheet: Indiana Geological Survey, scale 1:250,000.

Guennel, G. K., 1958, Miospore analysis of the Pottsville coals of Indiana: Indiana Department of Conservation, Geological Survey, Bulletin no. $13,101 \mathrm{p}$.

Heckard, J. M., undated, Water resources of Morgan County with emphasis on ground-water availability: Indiana Department of Conserva- tion, Division of Water Resources, map scale 1 inch $=1$ mile.

Hutchinson, H. C., 1956, Distribution, structure, and mined areas of coals in Clay County, Indiana: Indiana Department of Conservation, Geological Survey, Preliminary Coal Map 6, scale 1 inch $=2$ miles.

1959, Distribution, structure, and mined areas of coals in Warrick County, Indiana: Indiana Department of Conservation, Geological Survey, Preliminary Coal Map 8, scale 1 inch $=2$ miles.

1960, Geology and coal deposits of the Brazil Quadrangles, Indiana: Department of Conservation, Geological Survey, Bulletin no. 16 , Indiana, $50 \mathrm{p}$.

1964, Distribution, structure, and mined areas of coals in Dubois County, Indiana: Indiana Department of Conservation, Geological Survey, Preliminary Coal Map 10, scale 1 inch $=2$ miles.

1967, Distribution, structure, and mined areas of coals in Martin County, Indiana: Indiana Department of Natural Resources, Geological Survey, Preliminary Coal Map 11, scale 1 inch $=2$ miles.

Hutchinson, H. C., 1971, Distribution, structure and mined areas of coals in Daviess County, Indiana: Indiana Department of Natural Resources, Geological Survey, Preliminary Coal Map 15, scale 1 inch $=2$ miles.

Jones, G. B., Manifold, C. B., Bushnell, T. M., and Oyler, R. F., 1927, Soil survey of Clay County: U.S. Department of Agriculture, Bureau of Soils in cooperation with Purdue University Agricultural Experiment Station, $47 \mathrm{p}$.

Kelly, L. A., 1971, Soil survey of Sullivan County: U. S. Soil Conservation Service in cooperation with Purdue University Agricultural Experiment Station, $73 \mathrm{p}$.

1974, Soil survey of Daviess County: U.S. Soil Conservation Service in cooperation with Purdue University Agricultural Experiment Station, $85 \mathrm{p}$.

Mallot, C. A., 1946, The geology of Cataract Falls, Owen County, Indiana: Journal of Geology, v. LIV, no. 5, p. 322-326.

Miller, J. T., and Fitzpatrick, E. G., 1938, Soil sur- 
vey of Pike County, Indiana: U.S. Soil Conservation Service in Cooperation with Purdue University Agricultural Experiment Station, 68 p.

Montgomery, R. H., 1974, Soil survey of Vigo County: U.S. Soil Conservation Service in cooperation with Purdue University Agricultural Experiment Station, $121 \mathrm{p}$.

National Oceanic and Atmospheric Administration, 1974, Climates of the states, volume I--eastern states plus Puerto Rico and the U.S. Virgin Islands: New York, Water Information Center, Inc., $486 \mathrm{p}$.

Powell, R. L., 1966, Caves, speleology and karst hydrology, in Lindsey, A. A., ed., Natural Features of Indiana: Indiana Academy of Science and Indiana State Library, p. 116-130.

Purdue University, Agricultural Experiment Station, 1971, General soils maps and interpretation tables for the counties of Indiana: Purdue University Agricultural Experiment Station, Cooperative Extension Service and the Soil Conservation Service, Purdue Extension Publication AY-50, $184 \mathrm{p}$.

Ray, L. L., 1965, Geomorphology and quaternary geology of the Owensboro quadrangle, Indiana and Kentucky: U.S. Geological Survey Professional Paper 488, $72 \mathrm{p}$.

Robbins, J. M., Jr., 1974, Soil survey of Hendricks County: U.S. Soil Conservation Service in cooperation with Purdue University Agricultural Experiment Station, $69 \mathrm{p}$.

Ruhe, R. V., 1975, Geohydrology of karst terrain, Lost River watershed, southern Indiana: Bloomington, Ind., Indiana University Water Resources Research Center, Report of Investigations no. 7, $91 \mathrm{p}$.

Ruhe, R. V. and others, 1980, Urban hydrology in karst and water quality--inorganic and organic systems: Bloomington, Ind., Indiana University Water Resources Center, Report of Investigation no. $9,139 \mathrm{p}$.

Sanders, F. W., Brownfield, S., Lehman, S., and Fields, R., 1964, Soil survey of Owen County: U.S. Soil Conservation Service in cooperation with Purdue University Agricultural Experiment Station, $121 \mathrm{p}$.

Steen, W. J., 1968, Water resources of Hendricks County: Indiana Department of Natural Resources, map, 1 sheet.

Tharp, W. E., 1926, Soil survey of Gibson County, Indiana: U.S. Soil Conservation Service in cooperation with Purdue University Agricultural Experiment Station, $57 \mathrm{p}$.

Thornbury, W. D., 1937, Glacial geology of southern and south central Indiana: Indiana Department of Conservation, $138 \mathrm{p}$.

Thornbury, W. D., 1950, Glacial sluiceways and lacustrine plains of southern Indiana: Indiana: Indiana Department of Conservation, Geological Survey Bulletin no. 4, $21 \mathrm{p}$.

Ulrich, H. P.; Barnes, T. E., Bell, A. P., Myers, S., Allison, L. C., Nivison, T. E., and Veale, P. T., 1950, Soil survey of Morgan County: U. S. Department of Agriculture, Bureau of Plant Industries, Soils, and Agricultural Engineering in cooperation with Purdue University Agricultural Experiment Station, 148 p.

Watkins, F. A., Jr., 1963, Wabash basin comprehensive study, ground-water appraisal of the Patoka river basin and Patoka reservoir site, Indiana: U.S. Geological Survey, open-file report, 4 p. 1963, Ground-water resources of west-central Indiana, preliminary report: Vigo County: Indiana Department of Conservation, Division of Water Resources, Bulletin No. 17, $358 \mathrm{p}$.

Wier, C. E., 1952, Distribution, structure, and mined areas of coals in Vigo County, Indiana: Indiana Department of Conservation, Geological Survey, Preliminary Coal Map 1, scale 1 inch $=2$ miles.

1953, Distribution, structure, and mined areas of coals in Sullivan County, Indiana: Indiana Department of Conservation, Geological Survey, Preliminary Coal Map 2, scale 1 inch $=2$ miles.

Wier, C. E., 1953, Distribution, structure, and mined areas of coals in Pike County, Indiana: Indiana Department of Conservation, Geological Survey, Preliminary Coal Map 3, scale 1 inch $=2$ miles. 1958, Distribution, structure, and mined areas of coals in Warrick County, Indiana: Indiana Department of Conservation, Geological Survey, Preliminary Coal Map 7, scale 1 inch $=2$ miles.

Wier, C. E., 1967, Distribution, structure, and mined areas of coals in Knox County, Indiana: Indiana Department of Natural Resources, Geological Survey, Preliminary Coal Map 12, scale 1 inch = 2 miles.

Wier, C. E., and others, 1972, Sandstone aquifers in Eastern Sullivan County, Indiana: Proceedings of the Indiana Academy of Science, v. 82, p. 297-302.

Wingard, R. C., Jr., Hosteter, W. D., Weikert, G. D., and McCarter, P., Jr., 1975, Soil survey of Crawford County, Indiana: U.S. Soil Conservation Service in cooperation with Purdue University Agricultural Experiment Station, $60 \mathrm{p}$.

Wingard, R. C., Jr., Bernard, J. R., Coulter, J. W., and Hudson, G. L., 1980, Soil survey of Dubois County, Indiana: U.S. Soil Conservation Service in cooperation with Purdue University Agricultural Experiment Station, 117 p. 
Appendix 1. Description of soil associations.

[Source: U.S. Soil Conservation Service (1977b)]

\begin{tabular}{|c|c|c|c|c|c|c|}
\hline \multicolumn{2}{|c|}{ Soil association } & \multicolumn{2}{|c|}{ Soil description } & \multirow[b]{2}{*}{ Drainage } & \multirow{2}{*}{$\begin{array}{l}\text { Normal } \\
\text { slope } \\
\text { range } \\
\text { (per- } \\
\text { cent) }\end{array}$} & \multirow[b]{2}{*}{ Remarks } \\
\hline $\begin{array}{l}\text { Sym- } \\
\text { bol }\end{array}$ & $\begin{array}{l}\text { Major soil } \\
\text { series }\end{array}$ & $\begin{array}{l}\text { Surface } \\
\text { horizons }\end{array}$ & $\begin{array}{l}\text { Sub- } \\
\text { soils }\end{array}$ & & & \\
\hline Al & $\begin{array}{l}\text { Eel } \\
\text { Shoals }\end{array}$ & $\begin{array}{l}\text { Light-colored } \\
\text { loam. }\end{array}$ & $\begin{array}{l}\text { Light-colored } \\
\text { loam with } \\
\text { sand below } \\
\text { Lo inches. } \\
\text { do. } \\
\text { do. }\end{array}$ & $\begin{array}{l}\text { Moderately } \\
\text { well drained. } \\
\text { Poorly drained. }\end{array}$ & $0-2$ & $\begin{array}{l}\text { Parent materials are calcareous } \\
\text { loamy alluvium, found on wide } \\
\text { flood plains of streams origin- } \\
\text { ating in glacial deposits of } \\
\text { Wisconsin age. Fox soils are } \\
\text { associated. }\end{array}$ \\
\hline $\mathrm{A} 2$ & Fox & $\begin{array}{l}\text { Light-colored, } \\
\text { sandy loam, } \\
\text { loam, or silt } \\
\text { loam. }\end{array}$ & $\begin{array}{l}\text { Slay loam, } \\
\text { and sandy, } \\
\text { clay loam } \\
\text { with sandy } \\
\text { and gravelly } \\
\text { calcareous } \\
\text { lower layers. }\end{array}$ & Well drained. & $0-6$ & $\begin{array}{l}\text { Fox and terraces are formed from } \\
\text { loamy outwash over stratified } \\
\text { calcareous sand and gravel of } \\
\text { Wisconsin age. Genesee and Eel } \\
\text { formed from recent loamy alluvial } \\
\text { deposits on flood plains. Minor } \\
\text { soil types are Mahalasville and } \\
\text { Westland. }\end{array}$ \\
\hline & Genesee & $\begin{array}{l}\text { Light-colored } \\
\text { or brownish } \\
\text { loam. }\end{array}$ & $\begin{array}{l}\text { Light colored } \\
\text { or brownish } \\
\text { loam with } \\
\text { sand below } \\
40 \text { inches. } \\
\text { do. }\end{array}$ & $\begin{array}{l}\text { Moderately } \\
\text { well drained. }\end{array}$ & $0-2$ & \\
\hline A3 & Sloan & $\begin{array}{l}\text { Dark, silty } \\
\text { clay loam. }\end{array}$ & $\begin{array}{l}\text { Silty, clay } \\
\text { loam and clay } \\
\text { loam. }\end{array}$ & Poorly drained. & $0-2$ & $\begin{array}{l}\text { Parent materials are alluvial and } \\
\text { lacustrine deposits. Sloan and } \\
\text { Ross on flood plain, Vincennes }\end{array}$ \\
\hline & $\begin{array}{l}\text { Ross } \\
\text { Vincennes }\end{array}$ & $\begin{array}{l}\text { Dark loam. } \\
\text { Light-colored } \\
\text { loam. }\end{array}$ & $\begin{array}{l}\text { Loam. } \\
\text { Clay loam. }\end{array}$ & $\begin{array}{l}\text { Well drained. } \\
\text { Poorly drained. }\end{array}$ & $\begin{array}{l}0-2 \\
0-2\end{array}$ & $\begin{array}{l}\text { on low terraces. Minor soil } \\
\text { types are Bartle and Fox. }\end{array}$ \\
\hline & Zipp & $\begin{array}{l}\text { Light-colored, } \\
\text { silty clay or } \\
\text { silty, clay } \\
\text { loam. }\end{array}$ & $\begin{array}{l}\text { Silty clay or } \\
\text { silty, clay } \\
\text { loam. }\end{array}$ & do. & $0-2$ & \\
\hline A4 & $\begin{array}{l}\text { Haymond } \\
\text { Wakeland } \\
\text { Nolin }\end{array}$ & $\begin{array}{l}\text { Light-colored, } \\
\text { silty loam. } \\
\text { do. } \\
\text { do. } \\
\text { do. }\end{array}$ & $\begin{array}{l}\text { Silty loam or } \\
\text { silty, clay } \\
\text { loam. } \\
\text { do. } \\
\text { do. } \\
\text { do. }\end{array}$ & $\begin{array}{l}\text { Well drained. } \\
\text { Poorly drained. } \\
\text { Well drained. }\end{array}$ & $\begin{array}{l}0-2 \\
0-2 \\
0-2\end{array}$ & $\begin{array}{l}\text { Parent materials neutral to acid, } \\
\text { silty, alluvial deposits. } \\
\text { Located on flood plains. Minor } \\
\text { soils are Armiesburg, Cuba, } \\
\text { Genesee, Petrolia, and Steff. }\end{array}$ \\
\hline $\mathrm{C} 3$ & Princeton & $\begin{array}{l}\text { Dark-colored, } \\
\text { fine sandy } \\
\text { loam. } \\
\text { Light-colored, } \\
\text { fine sandy } \\
\text { loam. } \\
\text { Fine sandy } \\
\text { loam. }\end{array}$ & $\begin{array}{l}\text { Sandy, clay } \\
\text { loam. }\end{array}$ & $\begin{array}{l}\text { Very poorly } \\
\text { drained. } \\
\text { Somewhat poor- } \\
\text { ly drained. } \\
\text { Well drained. }\end{array}$ & $0-12$ & $\begin{array}{l}\text { Parental material is calcareous } \\
\text { outwash sand and eolian fine sand } \\
\text { deposited in Wisconsin time. } \\
\text { Found on level terraces with high } \\
\text { water table. Minor solls are } \\
\text { Bloomfield, Kings, and Vincennes. }\end{array}$ \\
\hline D2 & Henshaw & $\begin{array}{l}\text { Dark-colored, } \\
\text { silty clay } \\
\text { loam. } \\
\text { Dark-colored, } \\
\text { fine, sandy } \\
\text { loam. } \\
\text { Light-colored, } \\
\text { silt loam. }\end{array}$ & $\begin{array}{l}\text { Silty, clay } \\
\text { loam. } \\
\text { Sandy, clay } \\
\text { loam. } \\
\text { Silty, clay } \\
\text { loam. }\end{array}$ & $\begin{array}{l}\text { Very poorly } \\
\text { drained. } \\
\text { do. }\end{array}$ & $0-2$ & $\begin{array}{l}\text { Parent materials are stratified } \\
\text { silty lacustrine deposits and } \\
\text { sandy outwash or eolian deposits } \\
\text { found on nearly level lacustrine } \\
\text { plains. Minor soils are Shoals } \\
\text { and Wakeland. }\end{array}$ \\
\hline D3 & $\begin{array}{l}\text { Zipp } \\
\text { Markland } \\
\text { McGary }\end{array}$ & $\begin{array}{l}\text { Light-colored, } \\
\text { silty clay. } \\
\text { Light-colored, } \\
\text { silty loam. } \\
\text { do. }\end{array}$ & $\begin{array}{l}\text { Silty clay. } \\
\text { do. }\end{array}$ & $\begin{array}{l}\text { Very poorly } \\
\text { drained. } \\
\text { Well drained. } \\
\text { Poorly drained. }\end{array}$ & $\begin{array}{r}0-2 \\
2-12 \\
0-2\end{array}$ & $\begin{array}{l}\text { Zipp and McGary on nearly level } \\
\text { lake-plain uplands. Markland on } \\
\text { side slopes leading down to } \\
\text { streams. Minor soils are Evans- } \\
\text { ville, Henshaw, Montgomery, } \\
\text { Patton, and Steff. }\end{array}$ \\
\hline E5 & Negley & $\begin{array}{l}\text { Light-colored } \\
\text { loess or silt } \\
\text { loam. } \\
\text { Light-colored } \\
\text { loam. }\end{array}$ & $\begin{array}{l}\text { Silty, clay } \\
\text { loam. } \\
\text { Reddish sandy } \\
\text { clay loam. }\end{array}$ & Well drained. & $\begin{array}{l}18 \text { to } \\
>35\end{array}$ & $\begin{array}{l}\text { Parent materials are Wisconsin } \\
\text { loess over old reddish sandy clay } \\
\text { loam soils. Found on remnants of } \\
\text { terraces or outwashes of } \\
\text { Illinoian age. Minor soil is } \\
\text { Pike. }\end{array}$ \\
\hline
\end{tabular}


Appendix 1. Description of soil associations. (Continued)

\begin{tabular}{|c|c|c|c|c|c|c|}
\hline \multicolumn{2}{|c|}{ Soil association } & \multicolumn{2}{|c|}{ Soil description } & \multirow[b]{2}{*}{ Drainage } & \multirow{2}{*}{$\begin{array}{l}\text { Normal } \\
\text { slope } \\
\text { range } \\
\text { (per- } \\
\text { cent) }\end{array}$} & \multirow[b]{2}{*}{ Remarks } \\
\hline $\begin{array}{l}\text { Sym- } \\
\text { bol }\end{array}$ & $\begin{array}{l}\text { Major soil } \\
\text { series }\end{array}$ & \begin{tabular}{|l|l} 
Surface \\
horizons
\end{tabular} & $\begin{array}{l}\text { Sub- } \\
\text { soils }\end{array}$ & & & \\
\hline G & $\begin{array}{l}\text { Bloomfield } \\
\text { Ayrshire }\end{array}$ & $\begin{array}{l}\text { Light-colored, } \\
\text { fine sandy } \\
\text { loam. } \\
\text { Light-colored, } \\
\text { loamy fine } \\
\text { sand. } \\
\text { Light-colored, } \\
\text { fine sandy } \\
\text { loam. }\end{array}$ & $\begin{array}{l}\text { Sandy, clay } \\
\text { loam. } \\
\text { Bands of } \\
\text { sandy loam. } \\
\text { Sandy, clay } \\
\text { loam. }\end{array}$ & $\begin{array}{l}\text { Somewhat poor- } \\
\text { ly drained. }\end{array}$ & $2-18$ & $\begin{array}{l}\text { Parent material is calcareous } \\
\text { eolian sand of Wisconsin age. } \\
\text { Found on dunes and swales along } \\
\text { the Wabash River and its tribu- } \\
\text { taries. Minor soils are Iva } \\
\text { and Lyles. }\end{array}$ \\
\hline $\mathrm{H}$ & Al ford & $\begin{array}{l}\text { Light-colored, } \\
\text { silty loam. }\end{array}$ & $\begin{array}{l}\text { Silty, clay } \\
\text { loam. }\end{array}$ & Well drained. & $2-18$ & $\begin{array}{l}\text { Parent material leached loess } \\
\text { more than } 5 \text { feet thick. Found in } \\
\text { loessial hills. }\end{array}$ \\
\hline I3 & Fincastle & $\begin{array}{l}\text { Dark-colored, } \\
\text { silt loam or } \\
\text { silty, clay } \\
\text { loam. }\end{array}$ & $\begin{array}{l}\text { Silty, clay } \\
\text { loam, clay } \\
\text { loam, and } \\
\text { compact till } \\
\text { at } 40-60 \text { in. } \\
\text { Silty, clay } \\
\text { loam. }\end{array}$ & $\begin{array}{l}\text { Very poorly } \\
\text { drained. }\end{array}$ & $0-2$ & $\begin{array}{l}\text { Parent material loess over loam } \\
\text { textured glacial till. Minor } \\
\text { soils are Russell and Xenia. }\end{array}$ \\
\hline I4 & $\begin{array}{l}\text { Reesville } \\
\text { Ragsdale }\end{array}$ & $\begin{array}{l}\text { Light-colored, } \\
\text { silty loam. } \\
\text { Dark-colored, } \\
\text { silty loam or } \\
\text { silty, clay } \\
\text { loam. }\end{array}$ & $\begin{array}{l}\text { Silty, clay } \\
\text { loam. } \\
\text { do. }\end{array}$ & $\begin{array}{l}\text { Somewhat poor- } \\
\text { ly drained. } \\
\text { Very poorly } \\
\text { drained. }\end{array}$ & $0-2$ & $\begin{array}{l}\text { Developed entirely in Wisconsin } \\
\text { loess. Minor soils are Alford, } \\
\text { Fincastle, and Iva. }\end{array}$ \\
\hline I5 & $\begin{array}{l}\text { Iva } \\
\text { Vigo }\end{array}$ & $\begin{array}{l}\text { Light-colored, } \\
\text { silty loam. } \\
\text { do. }\end{array}$ & $\begin{array}{l}\text { Silty, clay } \\
\text { loam. } \\
\text { do. }\end{array}$ & $\begin{array}{l}\text { Somewhat poor- } \\
\text { ly drained. } \\
\text { do. }\end{array}$ & $0-2$ & $\begin{array}{l}\text { Formed on leached loess deposits } \\
\text { from } 3^{\frac{1}{2}} \text { to } 5 \mathrm{ft} \text { thick. Found on } \\
\text { till plains. }\end{array}$ \\
\hline J3 & Brookston & $\begin{array}{l}\text { Light-colored, } \\
\text { silt loam. } \\
\text { Dark-colored, } \\
\text { silt loam or } \\
\text { silty, clay } \\
\text { loam. }\end{array}$ & $\begin{array}{l}\text { Silty, clay } \\
\text { loam and } \\
\text { clay loam. } \\
\text { Silty, clay } \\
\text { loam. }\end{array}$ & $\begin{array}{l}\text { Somewhat poor- } \\
\text { ly drained. } \\
\text { Very poorly } \\
\text { drained. }\end{array}$ & $0-2$ & $\begin{array}{l}\text { Formed in loam glacial till and } \\
\text { drift and overlying loess. Found } \\
\text { on glacial till plains. Minor } \\
\text { soils are Celina and Miami. }\end{array}$ \\
\hline L4 & Brookston & $\begin{array}{l}\text { Dark-colored } \\
\text { silt loam or } \\
\text { silty, clay } \\
\text { loam. }\end{array}$ & $\begin{array}{l}\text { Clay loam } \\
\text { over cal- } \\
\text { careous } \\
\text { loam till. } \\
\text { Silty, clay } \\
\text { loam and } \\
\text { clay loam. } \\
\text { do. }\end{array}$ & $\begin{array}{l}\text { Somewhat poor- } \\
\text { ly drained. } \\
\text { Very poorly } \\
\text { drained. }\end{array}$ & $0-2$ & $\begin{array}{l}\text { Parent materials are calcareous } \\
\text { loam glacial till and overlying } \\
\text { loess. Found on end moraines and } \\
\text { rolling areas near streams that } \\
\text { direct glacial till plains. } \\
\text { Minor soil is Hennepin. }\end{array}$ \\
\hline L5 & $\begin{array}{l}\text { Hennepin } \\
\text { Crosby }\end{array}$ & $\begin{array}{l}\text { Light-colored, } \\
\text { silt loam. } \\
\text { Light-colored } \\
\text { loam. } \\
\text { Light-colored, } \\
\text { silt loam. }\end{array}$ & $\begin{array}{l}\text { Clay loam } \\
\text { over calcare- } \\
\text { ous loam till. } \\
\text { Loam and loam } \\
\text { till. } \\
\text { Silty, clay } \\
\text { loam and clay } \\
\text { loam. }\end{array}$ & $\begin{array}{l}\text { Well drained. } \\
\text { Well drained. } \\
\text { Somewhat poor- } \\
\text { ly drained. }\end{array}$ & $\begin{array}{l}18-735 \\
0-2\end{array}$ & $\begin{array}{l}\text { Parent materials glacial till and } \\
\text { loess. Found on rolling areas } \\
\text { and steep side slopes between } \\
\text { nearly level till-plain uplands } \\
\text { and terraces. Minor soil is } \\
\text { Celina. }\end{array}$ \\
\hline L6 & $\begin{array}{l}\text { Russell } \\
\text { Fincastle } \\
\text { Ragsdale }\end{array}$ & $\begin{array}{l}\text { Light-colored } \\
\text { silt loam. } \\
\qquad \text { do. } \\
\text { do. } \\
\text { Dark-colored } \\
\text { silt loam or } \\
\text { silty, clay } \\
\text { loam. }\end{array}$ & 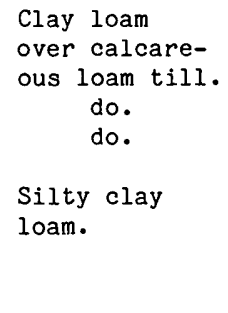 & $\begin{array}{l}\text { do. } \\
\text { Somewhat poor- } \\
\text { ly drained. } \\
\text { Very poorly } \\
\text { drained. }\end{array}$ & $\begin{array}{r}2-12 \\
0-2 \\
0-2\end{array}$ & $\begin{array}{l}\text { Parent materials loess and cal- } \\
\text { careous loam glacial till. Found } \\
\text { on end moraines and rolling areas } \\
\text { near streams that disect glacial } \\
\text { till plain. Minor soil is Xenia. }\end{array}$ \\
\hline
\end{tabular}


Appendix 1. Description of soil associations. (Continued)

\begin{tabular}{|c|c|c|c|c|c|c|}
\hline \multicolumn{2}{|c|}{ Soil association } & \multicolumn{2}{|c|}{ Soll description } & \multirow[b]{2}{*}{ Drainage } & \multirow{2}{*}{$\begin{array}{l}\text { Normal } \\
\text { slope } \\
\text { range } \\
\text { (per- } \\
\text { cent) }\end{array}$} & \multirow[b]{2}{*}{ Remarks } \\
\hline $\begin{array}{l}\text { Sym- } \\
\text { bol }\end{array}$ & $\begin{array}{l}\text { Major soil } \\
\text { series }\end{array}$ & $\begin{array}{l}\text { Surface } \\
\text { horizons }\end{array}$ & $\begin{array}{l}\text { Sub- } \\
\text { soils }\end{array}$ & & & \\
\hline L7 & $\begin{array}{l}\text { Hennnepin } \\
\text { Fincastle }\end{array}$ & $\begin{array}{l}\text { Light-colored } \\
\text { silt loam. } \\
\text { Light-colored } \\
\text { loam. } \\
\text { Light-colored } \\
\text { silt loam. }\end{array}$ & $\begin{array}{l}\text { Clay loam } \\
\text { over calcare- } \\
\text { ous loam till. } \\
\text { Loam and loam } \\
\text { till. } \\
\text { Clay loam } \\
\text { over calcare- } \\
\text { ous loam till. }\end{array}$ & $\begin{array}{l}\text { Well drained. } \\
\text { do. } \\
\text { Somewhat poor- } \\
\text { ly drained. }\end{array}$ & $\begin{array}{r}18- \\
>35 \\
0-2\end{array}$ & $\begin{array}{l}\text { Parent materials are loess and } \\
\text { glacial till. Found on rolling } \\
\text { areas and steep side slopes } \\
\text { between till-plain uplands. } \\
\text { Minor soil is Reesville. }\end{array}$ \\
\hline N1 & $\begin{array}{l}\text { Bartle } \\
\text { Peoga } \\
\text { Dubois }\end{array}$ & $\begin{array}{l}\text { Light-colored, } \\
\text { silty loam. } \\
\text { do. } \\
\text { do. }\end{array}$ & $\begin{array}{l}\text { Silty, clay } \\
\text { loam. } \\
\text { dce. } \\
\text { de. }\end{array}$ & $\begin{array}{l}\text { Poorly drained. } \\
\text { do. } \\
\text { do. }\end{array}$ & $\begin{array}{l}0-2 \\
0-2 \\
0-2\end{array}$ & $\begin{array}{l}\text { Acid, silty parent materials. } \\
\text { Found on lacustrine plains and } \\
\text { slack-water terraces. Minor } \\
\text { soils are Hosmer and Robinson. }\end{array}$ \\
\hline 01 & Hosmer & $\begin{array}{l}\text { Light-colored, } \\
\text { silty loam. - }\end{array}$ & $\begin{array}{l}\text { Silty clay } \\
\text { with fragipan. }\end{array}$ & Well drained. & $2-12$ & $\begin{array}{l}\text { Leached loess deposits usually } \\
4-6 \text { feet thick on rolling land- } \\
\text { scapes. Minor soils are Alford } \\
\text { and Cincinnati. }\end{array}$ \\
\hline 02 & $\begin{array}{l}\text { Zanesville } \\
\text { Wellston }\end{array}$ & $\begin{array}{l}\text { Light-colored, } \\
\text { silty loam. } \\
\text { do. }\end{array}$ & $\begin{array}{l}\text { Silty olay } \\
\text { with fragipan. } \\
\text { Silty olay } \\
\text { but lacks } \\
\text { fragipans. } \\
\text { Silty olay } \\
\text { with fragi- } \\
\text { pans. }\end{array}$ & $\begin{array}{l}\text { Well drained. } \\
\qquad \text { do. } \\
\text { Moderately } \\
\text { well drained. }\end{array}$ & $2-18$ & $\begin{array}{l}\text { Weathered, acid parent materials } \\
\text { of Pennsylvanian siltstone, } \\
\text { shale, and sandstone and overly- } \\
\text { ing loess. Found on gently } \\
\text { sloping unglaciated areas. Minor } \\
\text { soil is Muskingum. }\end{array}$ \\
\hline 03 & Cincinnati & $\begin{array}{l}\text { Light-colored } \\
\text { silt loam. } \\
\text { do. } \\
\text { do. }\end{array}$ & $\begin{array}{l}\text { Silty, clay } \\
\text { loam and } \\
\text { buried clay. } \\
\text { do. } \\
\text { do. }\end{array}$ & $\begin{array}{l}\text { Poorly drained. } \\
\text { Moderately } \\
\text { well drained. }\end{array}$ & $\begin{array}{l}0-2 \\
2-6\end{array}$ & $\begin{array}{l}\text { Parent materials are Wisconsin } \\
\text { loess and Illinoian till or } \\
\text { buried soils formed from Illi- } \\
\text { noian till. Found on slopes of } \\
\text { ravines and adjacent rolling } \\
\text { areas. Minor soils are Hickory } \\
\text { and Iva. }\end{array}$ \\
\hline$P$ & $\begin{array}{l}\text { Wellston } \\
\text { Zanesville }\end{array}$ & $\begin{array}{l}\text { Light-colored, } \\
\text { silty loam. } \\
\text { do. }\end{array}$ & $\begin{array}{l}\text { Silty, clay } \\
\text { loam. } \\
\text { Silty, clay } \\
\text { loam with } \\
\text { fragipan. } \\
\text { Loam and } \\
\text { silty loam } \\
\text { with shale. }\end{array}$ & $\begin{array}{l}\text { Well drained. } \\
\text { do. }\end{array}$ & $\begin{array}{r}12-25 \\
2-18\end{array}$ & $\begin{array}{l}\text { Parent materials are weathered } \\
\text { acid Mississippian and Pennsyl- } \\
\text { vanian siltstone, sandstone, and } \\
\text { shale, which are of ten covered } \\
\text { by a thin layer of loess. Found } \\
\text { on steep slopes of unglaciated } \\
\text { areas. Minor soils are Gilpin } \\
\text { and Muskingum. }\end{array}$ \\
\hline Q1 & $\begin{array}{l}\text { Bedford } \\
\text { Lawrence }\end{array}$ & $\begin{array}{l}\text { Light-colored } \\
\text { silt loam. } \\
\text { do. } \\
\text { do. }\end{array}$ & $\begin{array}{l}\text { Silty, clay } \\
\text { loam and } \\
\text { reddish clay. } \\
\text { clo. } \\
\text { Similar to } \\
\text { above but } \\
\text { grayer. }\end{array}$ & $\begin{array}{l}\text { Moderately } \\
\text { well drained. } \\
\text { Somewhat poor- } \\
\text { ly drained. }\end{array}$ & $\begin{array}{l}2-6 \\
0-2\end{array}$ & $\begin{array}{l}\text { Parent materials are red clayey } \\
\text { material derived from weathered } \\
\text { Mississippian limestone bedrock } \\
\text { and overlying thin loess. Found } \\
\text { on moderately sloping portions of } \\
\text { karst plain. Minor soil is } \\
\text { Zanesville. }\end{array}$ \\
\hline Q2 & $\begin{array}{l}\text { Hagerstown } \\
\text { Bedford }\end{array}$ & $\begin{array}{l}\text { Light-colored } \\
\text { silt loam. } \\
\text { do. } \\
\text { do. }\end{array}$ & $\begin{array}{l}\text { Silty, clay } \\
\text { loam and } \\
\text { reddi:sh clay. } \\
\text { Reddi:sh clay. } \\
\text { Silty, clay } \\
\text { loam and } \\
\text { reddi:sh clay. }\end{array}$ & $\begin{array}{l}\text { do. } \\
\text { Moderately } \\
\text { well drained. }\end{array}$ & $\begin{array}{r}2-18 \\
2-6\end{array}$ & $\begin{array}{l}\text { Parent materials are weathered } \\
\text { Devonian and Mississippian lime- } \\
\text { stone bedrock with thin loess } \\
\text { cap. Found on hilly part of } \\
\text { karst landscape. Minor solls are } \\
\text { Baxter, Corydon, Grayford, and } \\
\text { Haywood. }\end{array}$ \\
\hline Q3 & Corydon & $\begin{array}{l}\text { Light-colored } \\
\text { silt loam. } \\
\text { do. }\end{array}$ & $\begin{array}{l}\text { Silty, clay } \\
\text { loam ind red- } \\
\text { dish alay. } \\
\text { Reddish clay } \\
\text { with ahert } \\
\text { fragments. } \\
\text { Clay with } \\
\text { many stones. }\end{array}$ & Well drained. & $18->35$ & $\begin{array}{l}\text { Parent materials are weathered } \\
\text { Mississippian limestone with a } \\
\text { thin layer of loess on some } \\
\text { soils. Found on hilly and steep } \\
\text { parts of karst areas. Minor } \\
\text { soil is Haymond. }\end{array}$ \\
\hline
\end{tabular}


Appendix 2. Number of determinations of water-quality parameters.

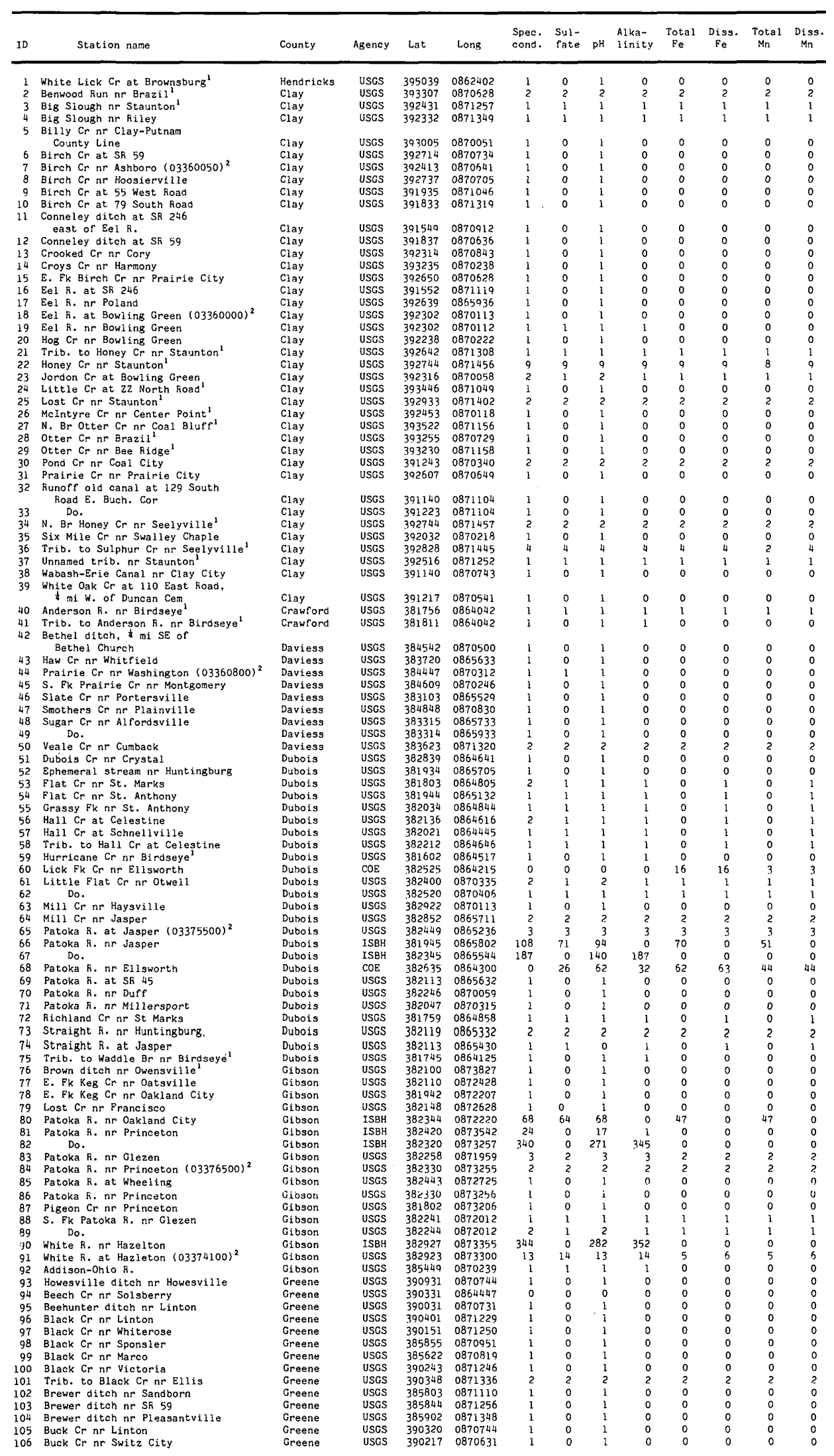


Appendix 2. Number of determinations of water-quality parameters. (Continued)

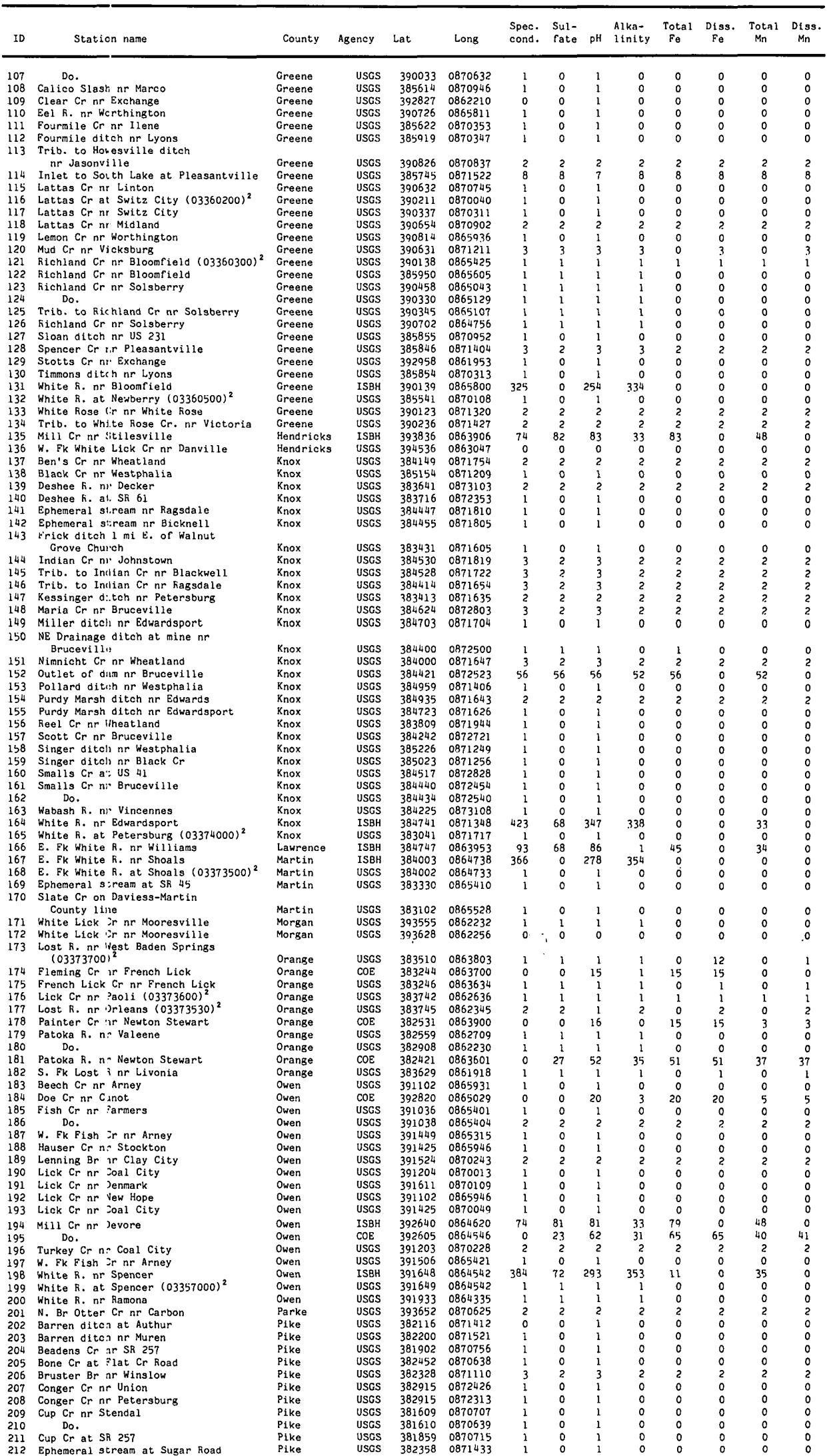


Appendix 2. Number of determinations of water-quality parameters. (Continued)

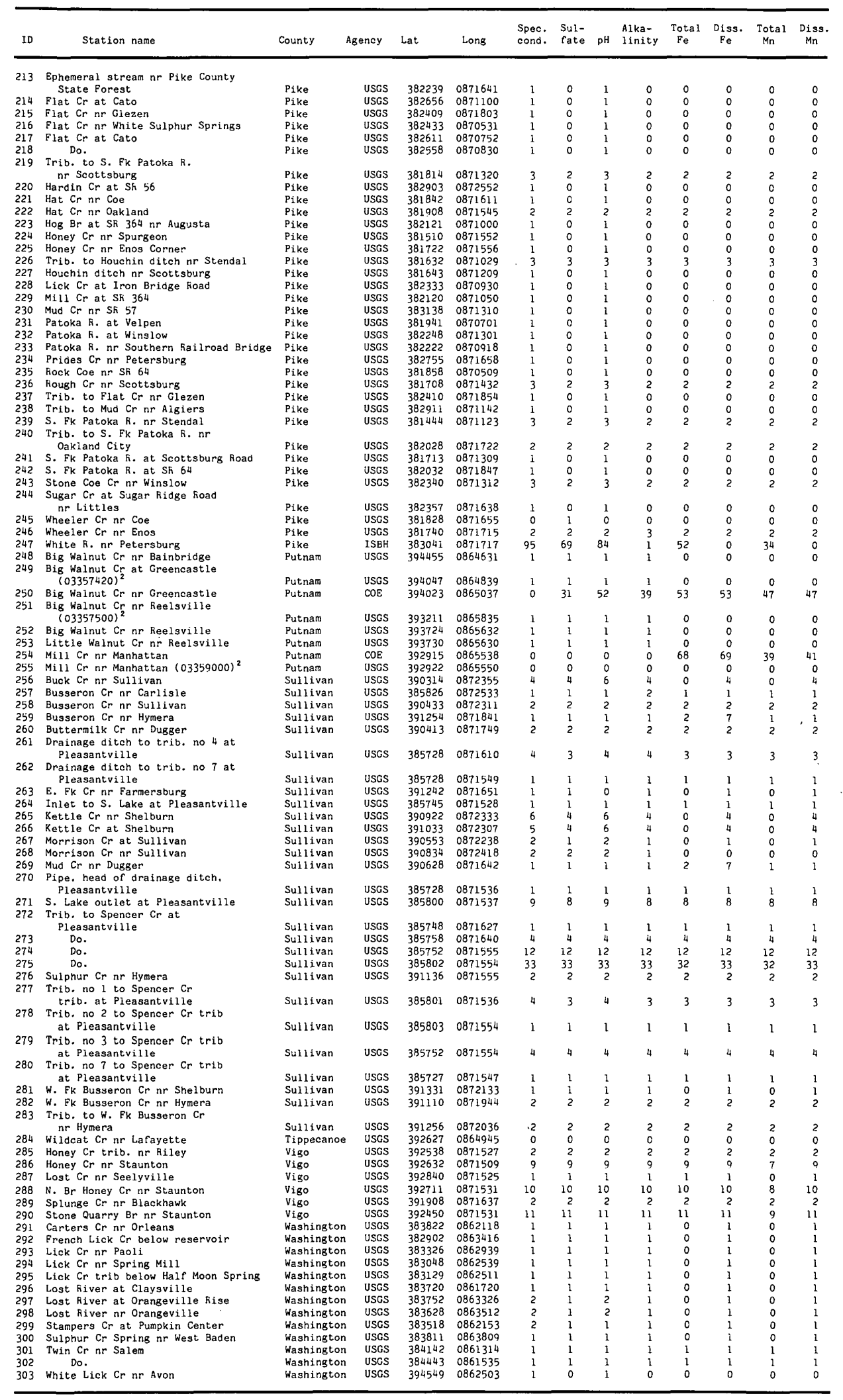

'Station location outside of Area 32 but data was used in analyses. 



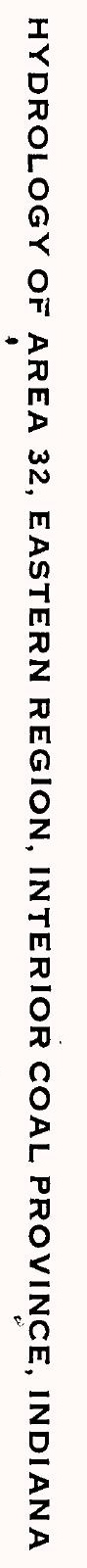

